University of Louisville

ThinkIR: The University of Louisville's Institutional Repository

Electronic Theses and Dissertations

$12-2018$

\title{
Microaggressions in LGB individuals: the protective role of positive LGB identity.
}

Ghazel Tellawi

University of Louisville

Follow this and additional works at: https://ir.library.louisville.edu/etd

Part of the Clinical Psychology Commons

\section{Recommended Citation}

Tellawi, Ghazel, "Microaggressions in LGB individuals: the protective role of positive LGB identity." (2018). Electronic Theses and Dissertations. Paper 3092.

https://doi.org/10.18297/etd/3092

This Doctoral Dissertation is brought to you for free and open access by ThinkIR: The University of Louisville's Institutional Repository. It has been accepted for inclusion in Electronic Theses and Dissertations by an authorized administrator of ThinkIR: The University of Louisville's Institutional Repository. This title appears here courtesy of the author, who has retained all other copyrights. For more information, please contact thinkir@louisville.edu. 
MICROAGGRESIONS IN LGB INDIVIDUALS: THE PROTECTIVE ROLE OF POSITIVE LGB IDENTITY

\author{
By \\ Ghazel Tellawi \\ B. A., University of St. Thomas, 2009 \\ M. A., University of Louisville, 2016 \\ A Dissertation \\ Submitted to the Faculty of the \\ College of Arts and Sciences of the University of Louisville \\ In partial fulfillment of the requirements for the degree of
}

Doctor of Philosophy

in Clinical Psychology

Department of Psychological and Brain Sciences

University of Louisville

Louisville, Kentucky

December 2018 

MICROAGGRESIONS IN LGB INDIVIDUALS: THE PROTECTIVE ROLE OF POSITIVE LGB IDENTITY

By

Ghazel Tellawi

B. A., University of St. Thomas, 2009

M. A., University of Louisville, 2016

A Dissertation Approved on

August $24^{\text {th }}, 2018$

By the following Dissertation Committee

Suzanne Meeks, Ph.D.

Dissertation Chair

Cara Cashon, Ph.D.

Maurice Gattis, Ph.D.

Richard Lewine, Ph.D.

Paul Rosen, Ph.D. 


\section{DEDICATION}

This dissertation is dedicated to my mother, Ghada, the most determined person to have ever existed, a pillar of strength, and my reason for all of this. Thank you for showing me all that a woman can be and achieve in this world. 


\section{ACKNOWLEDGEMENTS}

A huge thank you to Melissa Ellsworth for opening doors I did not know were possible, having confidence in who I am, and being my shoulder to lean on throughout the entirety of this journey.

Thank you to Jair Triviño for seeing strength in me when I was unable to, being one of my biggest advocates for so many years now, and for standing by me.

I am grateful to my committee members, Dr. Cashon, Dr. Gattis, Dr. Lewine, Dr. Meeks, and Dr. Rosen for providing me guidance and supporting me in this endeavor. Particular thanks go to Dr. Meeks, my dissertation chair, who stepped in as my mentor during one of the most critical phases of my graduate training. This also would not have been possible without the years of mentorship from Dr. Williams, who supported me, her OCD researcher, in stepping away from that world to pursue this passion. 


\section{ABSTRACT \\ MICROAGGRESSIONS IN LGB INDIVIDUALS: THE PROTECTIVE ROLE OF POSITIVE LGB IDENTITY \\ Ghazel Tellawi}

August 24, 2018

The purpose of the current study was to examine LGB identity from a multidimensional approach in the context of microaggressions. The aims of the study were as follows: 1) to examine whether positive and negative facets of LGB identities are correlated; 2) to determine whether positive LGB identity facets served as protective factors against the negative impact of microaggressions; 3) to explore the unique contribution of having a positive LGB identity against the negative impact of microaggressions when compared to other protective factors (social support and outness). Participants were 135 undergraduate students recruited through the University of Louisville's research participant pool. Correlational and regression analysis results indicated that some facets of positive and negative identity are correlated. Positive LGB identity was not significantly correlated with anxiety or depression as assessed by the Beck Anxiety Inventory (BAI) and Beck Depression Inventory-II (BDI-II), respectively. Social support and outness were negatively associated with the BDI-II and microaggressions were positively associated with the BDI-II. Microaggressions and social support predicted unique variance in depressive symptoms, although social support was not a statistically significant buffer against microaggressions. This study highlights 
the clinical importance of identifying coping skills and sources of resilience in LGB individuals. Future research, such as including a broader spectrum of sexual orientations, assessing intersectionality, and examining other sources of coping, such as selfompassion are discussed. 
TABLE OF CONTENTS

\begin{tabular}{lc}
\hline Topic & Page Number \\
\hline DEDICATION & iii \\
ACKNOWLEDGEMENTS & iv \\
ABSTRACT & ix \\
LIST OF TABLES & x \\
LIST OF FIGURES & \\
CHAPTER 1: INTRODUCTION & 1 \\
1. Minority Stress Theory: Distal Stressors & 4 \\
a. Microaggressions & 4 \\
b. Microaggressions and Mental Health & 9 \\
2. Protective Factors & 11 \\
a. Sexual Identity as a Potential Protective Factor & 13 \\
3. Defining LGB Identity & 15 \\
a. Models of LGB Identity & 16 \\
b. Minority Identity and Mental Health & 20 \\
4. Identity as a Buffer against Negative Outcomes of Discrimination & 23 \\
a. Sexual Minority Identity & 27 \\
$\quad$ i. LGB Identity as a Protective Factor & 28 \\
5. Study Aims and Hypotheses & 33 \\
a. Aim 1: Examine Identity from a Multidimensional Approach & 33 \\
b. Aim 2. Examine the Role of Positive Identity in Buffering against & 34 \\
c. Microaggressions 3. Examine Unique Contribution of Identity, Social Support, & 35 \\
CHAPTER 2: METHODS & 36 \\
1. Participants & 36 \\
2. Measures & 37 \\
\end{tabular}


3. Procedure 41

CHAPTER 3: RESULTS 42

1. Power Analysis 42

2. Sample Characteristics 42

3. Demographic Differences 44

4. Aim 1: Positive and Negative Identity 47

5. Aim 2: Microaggressions, Identity, and Mental Health 48

6. Aim 3: Protective Factors, Microaggressions, and Mental Health 52

7. Exploratory Analyses 55

8. Post Hoc Analyses 56

CHAPTER 4: DISCUSSION

1. Sample Overview 58

2. Positive and Negative Identity 59

3. Identity Dimensions and Bisexuality 61

4. Positive Identity, Microaggressions, and Mental Health 61

5. External Coping Resources 63

6. Limitations 66

7. Implications and Future Directions 68

$\begin{array}{ll}\text { REFERENCES } & 73\end{array}$

APPENDICES

Appendix A. Study Questionnaires 92

$\begin{array}{ll}\text { Curriculum Vitae } & 112\end{array}$ 


\section{LIST OF TABLES}

Table 1: Demographic Information 37

Table 2: Study Variable Descriptives 43

Table 3: Study Variable Descriptives by Sexual Orientation 46

Table 4: LGBIS Subscale Pearson Bivariate Correlations 48

Table 5: T-tests Comparing LGBIS Subscale Scores by Outness Group 56 


\section{LIST OF FIGURES}

Figure 1: Interaction between Microaggressions and Identity Centrality with Respect to Depressive Symptoms

Figure 2: Interaction between Microaggressions and Identity Affirmation with Respect to Depressive Symptom

Figure 3: Interaction between Microaggressions and Outness with Respect to Depressive Symptoms 


\section{CHAPTER I}

INTRODUCTION

\section{Overview}

Lesbian, gay, and bisexual individuals (LGB) face a wide range of experiences of victimization, ranging from violent acts, such as torture or murder (Amnesty International, 2001) to discriminatory experiences, such as being fired from the workplace based on their sexual orientation (Mays \& Cochran, 2001). Experiences of prejudice and discrimination have been associated with a host of poor mental and physical health outcomes in ethnic and sexual minority individuals (Meyer, 2003). This includes increased rates of physical problems, such as hypertension, cancer, flu, and general physical symptom severity (Frost, Lehavot, \& Meyer, 2015; Denton, 2012). Mental health issues are also associated with experiences of discrimination, with LGB individuals reporting increased levels of depression, post-traumatic stress, anxiety, anger, and substance use (Herek, Gillis, \& Cogan, 1999; McKirnan \& Peterson, 1989). Society has advanced in terms of acceptance of diversity and condemnation of overt prejudice, however, microaggressions remain a serious and understudied issue. While "oldfashioned" discrimination is committed outright and clearly recognizable, 
microaggressions are seen as brief and subtle slights, that may or may not be intentional, that communicate hostile and negative viewpoints toward sexual minority individuals (Sue, 2010; Nadal, 2008). Oftentimes, the victim is left with doubt about whether they have actually experienced a microaggression, and if the perpetrator's microaggression was motivated by the victim's minority status (Sue et al., 2003).

Research with ethnic minority individuals has indicated that microaggressions are problematic for those who experience them, with studies finding they are linked with negative affect, depression, anxiety, anger, and feelings of alienation (Nadal, Griffin, Wong, Hamit, \& Rasmus, 2014; Sue, Bucceri, Lin, Nadal, \& Torino, 2007). Recently, similar findings have been seen in LGB individuals, with studies linking microaggressions to relationship difficulties, reductions in self-esteem, increased anxiety and depression, posttraumatic stress disorder (PTSD), and difficulty with identity formation (Wright \& Wegner, 2012; Nadal et al., 2011a; Nadal et al., 2011b). They are particularly harmful because of their ambiguity and because they can be downplayed or denied by the victim or the perpetrator (Sue et al., 2011). Thus, it is hard to prove that microaggressions are occurring, and the victim is left wondering whether they really experienced a microaggression at all (Sue et al., 2011), with this ambiguity leading to anxiety and rumination (Nadal et al., 2016). Given that experiencing microaggressions is an expected and unavoidable stressor, it is important to examine coping methods in victims of microaggressions, however, very little research has been conducted in this area, particularly in LGB individuals.

Most studies examining coping in LGB individuals have focused on social support, which has been shown to have a buffering effect against the negative outcomes 
associated with experiences of prejudice (Russell \& Richards, 2003). While this is beneficial, research has often failed to address the need for coping resources that operate at the personal level, when an individual does not have access to such support or these external sources are not enough. In the context of the minority stress model, an individual's sexual identity may serve as a potential coping method (Meyer, 2003). Examination of minority identity has proven to be a promising line of research in ethnic minority individuals (Sellers \& Shelton, 2003), but has been extended to sexual minority individuals in a very limited way. Studies on the relationship between experiences of discrimination or microaggressions, mental health, and identity have often focused on one facet of identity, leaving much of the relationship unclear (Fingerhut, Peplau, \& Gable, 2010). Other studies have examined the role of negative aspects of identity, such as internalized homonegativity, ignoring the potentially buffering roles of positive facets of identity (Denton, Rostosky, \& Danner, 2014). Also, the individual roles of various factors is unclear, as the study of factors such as identity centrality have yielded mixed results, with some stating that higher centrality increases the negative impact and others stating that it serves as a buffer.

The proposed study aims to examine whether possessing a positive LGB identity serves a protective role against negative mental health outcomes in the face of microaggressions toward LGB individuals. LGB identity, experiences of homonegative microaggressions, anxiety, and depression will be evaluated. Additionally, outness and social support will be assessed in order to determine the unique contributions of identity, outness, and social support as protective factors, given that they are distinct but related. 


\section{Minority Stress Theory: Distal Stressors}

Minority stress theory posits that the increased rates of negative mental health outcomes seen in sexual minority individuals are directly caused by unique stressors these individuals experience (Meyer, 1995). These stressors are conceptualized in terms of proximity to the individual, with distal stressors comprising experiences of unique stress faced by sexual minority individuals that are external to the individual, such as acts of prejudice by other individuals (Meyer, 1995). Proximal stressors are internal and related to one's identity as belonging to a minority group, and are influenced by the distal stressors that one experiences (Meyer, 2003). Distal stressors occur outside one's control and exacerbate proximal stressors, thus they are viewed as the core problem; examples of distal stressors include homophobia, discrimination, and microaggressions.

\section{Microaggressions}

Recently, changes in social institutions, policies (such as the legalization of same sex marriage), and public tolerance have led to decreases in overt discrimination towards LGB individuals, however, these changes have been accompanied by a shift toward covert acts known as microaggressions (Pierce, 1974; Sue, 2010). While they may not be intended to cause harm, these slights communicate negative attitudes regarding sexual minority individuals (Nadal, 2008).

As described in minority stress theory, microaggressions are consistent with distal stressors and are an added burden for minority individuals that are associated with unique distress. However, microaggressions are theoretically distinct from outright discrimination and present a unique set of psychological dilemmas, described in microaggressions theory (Nadal, Whitman, Davis, Erazo, \& Davidoff, 2016).The first 
dilemma includes a clash of realities, as individuals may have different interpretations of microaggressions depending on whether they are committing or experiencing the microaggression. Individuals are often unaware that they are committing microaggressions, however, this does not reduce their impact on the victim. Also, the victim of microaggressions is often left confused as to the source of the perpetrator's hostility, and will be left questioning whether the hostility was a result of their minority status (Sue et al., 2007). This questioning is problematic, as the victim of the microaggression may engage in rumination over the incident, leading to anxiety. They may spend time wondering whether it has really occurred (Sue et al., 2011). Nonminority individuals are often not even aware that microaggressions are occurring, such as heterosexual individuals not realizing there is no open-ended response on a demographics form assessing sexual orientation, which relates to the second dilemma, the invisibility of unintentional bias. The third psychological dilemma then relates to the perceived minimal harm of microaggressions, as most individuals may see such an oversight on a demographics form as minor and not worthy of becoming distressed by, even though this may be invalidating to an LGB individual. The fourth psychological dilemma involves the catch-22 of how to respond to a microaggression (Nadal et al., 2016). Given that many individuals interpret microaggressions as innocuous, victims then have to decide how to react, either doing nothing out of fear, hopelessness, or confusion about whether it really happened, or confronting with anger (a natural reaction), which may lead to negative consequences, such as being told they are overly sensitive or paranoid (Sue et al., 2011). The confusion and questioning are in part because microaggressions are often automatic and can be as subtle as a dismissive look or tone, 
with this subtlety making it easy to mask a microaggression as innocent, dismissing the victim's experience (Sue et al., 2011). Upon confrontation, this dismissal of the victim's feeling further invalidates the victim, compounding the negative impact of microaggressions (Sue et al., 2011).

To illustrate the confusing and distressing nature of microaggressions, a prominent microaggressions researcher, Derald Sue, described an experience of a microaggression (Sue et al., 2011) in which he and another minority friend were asked to move from the front to the back of a relatively empty airplane in order to "distribute the weight" despite three White individuals having seated themselves in the front of the airplane after Sue and his colleague were seated. Upon confronting the flight attendant who made the request, she denied that her reasons were race-related and became defensive, rationalizing her actions. Because of her ability to rationalize, Sue stated that he continued wondering whether he had correctly perceived her actions to be motivated by race, if it were not for his colleague sharing a similar perception of the incident. Furthermore, the chronic, cumulative nature of microaggressions has been shown to lead to a hostile racial climate and linked with self-doubt, frustration, and isolation in a sample of African American participants (Solorzano et al., 2000). This is illustrated in Sue's example, as he questioned and experienced turmoil over the experience for the remainder of the flight. Thus, while perpetrators of microaggressions, such as the flight attendant, believe microaggressions are minor acts, Sue (2003) believes that "this contemporary form of racism is many times over more problematic, damaging, and injurious to persons of color than overt racist acts." 
While most of the literature on microaggressions exists in ethnic minority individuals, much of this research is applicable to sexual minority individuals, who also possess a stigmatized identity and face similar experiences of discrimination. Previous theoretical papers (Nadal, Rivera, \& Corpus, 2010; Sue, 2010) have established a number of categories of microaggressions against LGB individuals, including oversexualization (associating sexual orientation with sexual behaviors), homophobia (fear of and hatred toward homosexuality), use of heterosexist language (using words that show preference toward a heteronormative lifestyle, such as husband or wife, prior to marriage equality), perception of sinfulness (belief that any LGB identity is inherently bad), assumption of abnormality (LGB identity is indicative of psychopathology), denial of one's heterosexism (an individual's refusal to acknowledge their bias), endorsing heteronormative culture and behaviors (traditions are based on heterosexual norms, such as asking women about their boyfriends or only teaching about heterosexual sex in sex education classes).

Platt and Lenzen (2013) sought to provide further empirical backing for Sue's (2010) seven themes of LGB microaggressions and to extend this typology by conducting focus groups with 12 LGBTQ undergraduate students aged 18-22 in the Midwest and including new themes that arose during the qualitative interviews. The researchers found seven themes, including five that were consistent with Sue's (2010) typology, including endorsement of heteronormative culture, sinfulness, homophobia, heterosexist language, and oversexualization. Two additional themes were found, including undersexualization and microaggressions as humor. One theme from Sue (2010) was not found (LGB identity as abnormal), which may indicate the start of a societal shift toward increased 
acceptance of sexual minority identities. Despite this, individuals reported that microaggressions were especially harmful, increasing feelings of loneliness and marginalization, when the individual committing the microaggression was not aware of the individual's sexual minority status. This study highlighted the variety of microaggressions that sexual minority individuals face, and the impact that these acts have on the victim.

While microaggressions fall under the umbrella of distal stressors, they cover a unique range of experiences that are different to those of overt racism, homophobia, or discrimination, and have been shown to predict more variance in distress related to experiences of heterosexism than overt victimization, indicating the importance of studying them separately (Woodford, Kulick, Sinco, \& Hong, 2014). Microaggressions are also different from overt discrimination because the perpetrator is often unaware and the victim is left questioning the cause of the hostility, which may contribute to increased distress as reported in the Woodford et al. (2014) study. Additionally, the findings of Platt \& Lenzen (2013) emphasize the unique experience of possessing an "invisible minority" status, and the impact of microaggressions on identity development and disclosure. Highlighting the differences in experiences of stigma between LGB individuals and ethnic minority individuals with visible minority status, Hatzenbuehler, Nolen-Hoeksema, and Dovidio (2009) found that LGB individuals report more social isolation and less social support than ethnic minority individuals. Given that in this study social isolation mediated the relationship between experiencing stigma and distress, it appears this lack of access to social support is critical in LGB mental health. Thus, while concealment may protect against experiences of some microaggressions, it is also linked 
with negative outcomes (Pachankis, 2008), as is possessing a concealable identity regardless of whether one has faced discrimination (Quinn \& Chaudoir, 2009). Hence, experiencing a microaggression may further silence sexual minority individuals, or prompt them to reveal their minority status in an unsafe situation or before they are ready to disclose, in order to address the microaggression, thus adding to the negative impact of microaggressions in individuals with concealable identities (Platt \& Lenzen, 2013). Therefore, it is particularly important to study the effects of microaggressions on LGB individuals.

\section{Microaggressions and Mental Health}

Microaggressions result in a host of negative reactions from their victims, consistent with minority stress theory; Nadal et al. (2016) stated that these chronic experiences are an added burden on minority individuals in addition to everyday stressors. Nadal et al. (2011b) conducted focus groups using semi-structured interviews to assess whether LGB individuals are able to recognize microaggressions, how they react to experiencing a microaggression, and how they cope with microaggressions over time. A total of 26 ethnically diverse participants, including five gay women, 11 gay men, and 10 bisexual women aged $18-55(M=25.7, S D=10.43)$ were recruited from a northeastern metropolitan area at an undergraduate university or through community recruitment (student groups; listservs) for this qualitative study, which placed participants in five focus groups. Nadal and colleagues (2011b) found that virtually all participants reported feeling distressed after experiencing a microaggression, and reported feelings such as anger, frustration, sadness, and hopelessness. Lesbian and bisexual women 
reported feeling objectified and gay men felt accused of being sexual predators (Nadal et al., 2011b).

Further establishing the negative association between microaggressions and mental health, Wright and Wegner (2012) conducted an online survey with 120 lesbian (34\%), gay (55\%), and bisexual (12\%) individuals, with a mean age of $34(S D=11.6)$. Results indicated that sexual orientation-based microaggressions were associated with negative feelings about and difficulty developing one's LGB identity and decreased selfesteem. Furthermore, witnessing or experiencing microaggressions toward sexual minority individuals is associated with anxiety, and direct experiences are associated with increased depressive symptoms (Silverschanz, Cortina, Konik, \& Magley, 2008) in a sample of 351 northwestern LGB college students. Experiencing microaggressions has also been associated with reports of anxiety and PTSD by LGB participants in focus groups (Nadal et al., 2011b).

Possessing multiple minority identities, such as both an ethnic and sexual minority identity, adds increased complexity to one's experience of microaggressions. This intersectionality was examined in a sample of 89 black youth aged 16-24 experiencing homelessness, of whom half identified as sexual or gender minority individuals (Gattis \& Larson, 2017). Through the use of self-report measures and structured in-person interviews, it was determined that the perception of microaggressions directed toward one's sexual or racial minority identities was correlated with depressive symptoms.

Microaggressions may also inhibit individuals' ability to embrace their LGB identity and their likelihood of "coming out" (Nadal et al., 2011a). Using the same 
methodology and sample as Nadal et al. (2011b), results indicated that sexual minority individuals who experience microaggressions at a younger age experience difficulty with identity formation. This may be due to findings that experiences of microaggressions during youth are associated with increased internalized homonegativity, negative feelings toward and hardship with one's sexual identity, and attempts to deny or hide one's LGB identity, which hinders positive identity formation (Wright \& Wegner, 2012). The findings presented in this section establish that LGB individuals experience a variety of microaggressions on a regular basis, and that these recurrent experiences are associated with distress, as established in the previous sections on microaggressions broadly.

\section{Protective Factors}

The negative impact of microaggressions has been established, however, studies regarding sources of coping in LGB individuals are lacking, even outside the context of discriminatory experiences. In one of few studies examining coping in LG individuals, Spencer and Patrick (2009) conducted a self-report study and found in a sample of 127 LG individuals aged 18-30, that while LG status was associated with higher depressive symptoms, personal mastery (the degree to which one believes they control factors that affect their lives) and social support were associated with lower depressive symptoms and increased self-esteem. When personal mastery and social support were entered into a regression model, LG status was no longer predictive of variance in symptoms of depression. This study highlights the importance of personal resources, such as personal mastery, as sources of improved well-being. As social support is not always available, it is important that individuals develop personal coping methods. With such little research 
on protective factors, this study greatly contributes to our understanding of protective factors in LG individuals.

Coping in the face of discrimination has received even less research attention than research on LGB coping in general. In one study (Mustanksi, Newcomb, \& Garofalo, 2011), an ethnically diverse sample of 425 LGB individuals, aged 16-24, was examined in order to explore coping processes in the face of victimization. Through self-report measures, the researchers found that psychological distress varied considerably within the sample, indicating that individuals possess various resources that protect them from the negative effects of victimization. Additionally, victimization was significantly positively associated with psychological distress, with peer support functioning as a protective factor in this relationship. This study was important in establishing social support as a coping method.

Extending this body of literature using focus groups involving 68 LGBTQ youth, and 11 who identified as "straight allies," aged 14-24, Higa and colleagues (2014) determined a variety of methods by which LGBTQ youth from Washington State coped with possessing a stigmatized identity. Participants reported fighting back, advocating for rights, gaining self-acceptance, and recognizing that they are unique. Youths stated that while they did not have many LGBTQ peers, they had supportive friend networks and adults who provided help. Individuals reported that school and neighborhoods were sources of negative factors, as they often experienced verbal and physical harassment, and a lack of action from school authorities. Religion was also discussed as a negative factor, as they often received negative messages about their identities, although research has shown same-sex affirming religious communities are associated with less harmful 
effects of discrimination (Gattis, Woodford, \& Han, 2014). These findings highlight the fact that LGBTQ individuals experience discrimination from a young age, and illuminate the importance of developing healthy coping methods and supportive communities.

Finally, Nadal et al. (2011b) used focus groups and content analysis of themes to identify coping methods in the face of microaggressions, including behavioral and cognitive reactions. Behavioral coping methods included passive reactions (walking away), confrontational coping (confronting the perpetrator), and protective coping (ensuring one's safety). Cognitive reactions varied, including empowerment, pressure to match heteronormative culture, and acceptance that microaggressions are part of everyday life. Nadal and colleagues (2011b) suggest that mental health professionals focus on the development of coping mechanisms in the face of microaggressions, including the development of well-formed personal and group identities.

\section{Sexual Identity as a Potential Protective Factor}

Coping at the personal level is important, as oftentimes an individual may not have access to a supportive LGB network, or they may lose their existing support system upon coming out. Furthermore, external resources alone may not be enough to cope with distress. For example, studies have shown that family support is significantly associated with reduced distress, but the buffering effects may be minimal in the face of victimization (e. g., Mustanski et al., 2011). While family and peer support both served as protective factors to various extents in this study, they were not able to eliminate the negative outcomes associated with victimization, as these negative effects were still significant in a multivariate model that included peer and family support. Another study showed the positive relationship between positive identity valence and lower levels of 
depression, while connectedness to the community showed no association with depression in 296 LGB individuals aged 18-59 in New York City (Kertzner, Meyer, Frost, \& Stirratt, 2009). Additionally, due to challenges for LGB individuals in forming social support networks (Williams, Connolly, Pepler, \& Craig, 2005), it may be important to encourage the development of protective factors that function on the individual level. These findings highlight the need to identify additional coping strategies to protect further against the negative impact of such experiences.

Studies have found that while many factors related to possessing a stigmatized status can be seen as negative, many individuals view their identities positively (e. g., Higa, et al., 2014). While LGBTQ youth are also at risk for mental and physical health issues due to factors such as bullying, little research has examined positive and negative life factors. Focus groups using qualitative methods to identify themes (Higa et al., 2014) found that LGBTQ youth discussed issues surrounding identity more positively than negatively, including the notion that LGBTQ is a flexible descriptor of identity. This flexibility was not suggested as being confusing or unstable, but as allowing the youth control over how they personally identify and how they choose to present their identities. Additionally, their identity was a source of control, as many youths stated that their identities were a way to reclaim derogatory terms. Furthermore, participants spoke about visibility of their identities being a source of pride. Possessing a positive identity is thought to help an individual deflect the blame of a microaggression toward the perpetrator, rather than internalizing the act and questioning what is wrong with their minority identity (Sue, 2010). Thus, it is likely important to facilitate the development of 
a healthy identity as a coping method when faced with negativity, which should help buffer against negative impact of microaggressions.

\section{Defining LGB Identity}

Models of LGB identity are based on the experiences of gay men, bisexual men, lesbian women, and bisexual women which may vary widely, raising the question of whether it is appropriate to develop models for sexual minority individuals as a group. Even the notion of studying lesbian women, gay men, and bisexual individuals separately undermines the complexity of nuanced experiences of LGB individuals (Moradi, Mohr, Worthington, \& Fassinger, 2009). While developing models and conducting research on different groups individually may have its benefits, it is not practical. In addition, there are many reasons that it may be appropriate to group LGB members regardless of gender and sexual orientation. LGB individuals of all categories face similar stigma related to deviating from heteronormative culture, internalizing societal stigma, development of a collective identity, and the need for disclosure (Mohr \& Kendra, 2011). In studying LGB individuals collectively, one can develop a broader understanding of identity and what it means to be a person who experiences stigma based on their sexual orientation. This captures the experience of the broader community, and allows for comparison across LGB individuals.

Regardless of gender and sexual orientation label, a positive identity indicates positive feelings and thoughts about the self, contributing to positive health (Riggle, Mohr, Rostosky, Fingerhut, \& Balsam, 2014). In LGB individuals, developing a positive identity is a continuous process that involves an individual and group identity, and is a difficult and often lifelong process due to discrimination (Feldman \& Wright, 2013). 
Identity is complex, so even the most comprehensive theories may not be able to consider all components that constitute LGB identity. Despite this, many theories have been proposed to conceptualize LGB identity. Historically, LGB identity was viewed as a progression through stages, with the Cass model (Cass, 1979), a series of six stages described below in further detail, standing out as the most prominent stage model. Other theories have taken a multidimensional approach, with LGB identity possessing both positive and negative facets that can fluctuate throughout the lifespan (Mohr \& Fassinger, 2000). Identity development and outness have been used interchangeably in the literature, however, they are distinct constructs. Identity development is about one's discovery and labeling of their LGB identity, while outness solely refers to the degree to which one has disclosed their LGB identity to the people around them (Jordan \& Deluty, 1998). A complete discussion of all LGB identity theories is beyond the scope of this review, thus discussion will be limited to the two most prominent theories.

\section{Models of LGB Identity}

In the Cass model (Cass, 1979), LGB individuals begin in the identity confusion stage, where they first realize their same sex attraction. This stage is associated with a lack of clarity about one's sexual identity and distress related to their realization. In the second stage, identity comparison, the individual begins to acknowledge that they may be an LGB individual, a distressing stage, as the individual becomes aware of their difference from heterosexual peers, resulting in feelings of alienation. Once the individual commits further to their identity, they may reluctantly seek out support of other LGB individuals in the third stage, identity tolerance. In this stage, the individual may present two separate images, one that is private and allows expression of LGB 
identity, and one that is public and maintains the image of a heterosexual lifestyle. It is thought that increased contact with LGB individuals fosters comfort with one's own identity, and aids the shift into identity acceptance, the fourth stage (Cass, 1984a). This is seen as a stable point in one's identity, as identity confusion, isolation, and internalized stigma have been largely resolved (Cass, 1984a). The stability of acceptance of one's identity allows the individual space to develop pride regarding their sexuality, as well as the development of loyalty to LGB culture in general. LGB individuals who have developed these traits are thought to have moved into stage five: identity pride. In this stage, the individual experiences anger regarding societal stigma of LGB identity, and purposely increases disclosure and exposure to heterosexual individuals in order to prove LGB equality to heterosexuality. If an individual consistently receives negative responses, they may internalize this negativity, and move into identity foreclosure (Cass, 1979). Individuals who experience positive reactions are thought to move into identity synthesis, the sixth stage. In this stage, sexual minority individuals develop less extreme views on heterosexual individuals and also recognize that they have more to their identity than just their sexual orientation. The person is able to integrate their LGB lifestyle into their public life, reducing the need to divide their life into an LGB side and a public, heteronormative life (Cass, 1979).

Support exists for the Cass model, with Cass (1984a) using self-report measures showing that individuals who see themselves in a certain stage of her model agreeing that the profile provided for that stage corresponds more closely to their current experience than other stages. Furthermore, Adams \& Phillips (2009) conducted qualitative interviews with LGBT Native American individuals and found that while two 
developmental pathways emerged, one followed Cass' proposed identity formation trajectory. While there is such support for the Cass model, it has been criticized for assuming that every individual's experience of identity formation follows the same trajectory, regardless of environmental context (D’Augelli, 1994). The Cass model also fails to include issues of diversity, such as the interplay between sexual and ethnic identity, and how these differences may impact one's development (Fassinger, 1991). Furthermore, Cass (1979) presented identity as a series of potential stages, but did not give a distinct definition of LGB identity, which was later included in her critique on LGB identity formation literature (Cass, 1984b). She also noted that the model may need to be adapted to reflect shifting societal attitudes toward LGB identity (Cass, 1979), and movement into a stage categorized by anger may not be necessary for all LGB individuals depending on their societal context (Eliason, 1996). The Cass model also fails to distinguish between an individual process of identity formation and the process of developing a group identity. Furthermore, her model has also been critiqued for being based largely on gay and bisexual men (Fassinger, 1991).

As a result of these deficits of the Cass model and stage theories broadly, recent research has accepted that a uniform, linear stage progression may not be the best way to capture LGB identity (Rosario, Schrimshaw, \& Hunter, 2008). Literature has shifted toward viewing identity as a multidimensional construct that fluctuates throughout the lifespan, an idea presented by Mohr and Fassinger (2000) and later expanded by Mohr \& Kendra (2011). This approach allows for many paths toward and facets within a healthy identity. In embracing this approach, research has come to focus on defining the key variables that comprise LGB identity (Mohr \& Kendra, 2011). In this approach, LGB 
identity is composed of and shaped by eight constructs: concealment motivation, identity uncertainty, internalized homonegativity, difficult process, acceptance concerns, identity superiority, identity centrality, and identity affirmation (Mohr \& Kendra, 2011). Concealment motivation is the degree to which individuals believe they must hide their sexual orientation. Identity uncertainty reflects a lack of clarity regarding one's sexual identity. The internalization of societal stigma regarding one's identity and the subsequent rejection of one's LGB status is referred to as internalized homonegativity. The perception of difficulty in developing an LGB identity is reflected in the construct referred to as difficult process. Acceptance concerns refers to how much one is preoccupied with potential rejection or discrimination based on one's LGB identity. Identity superiority reflects the level to which one favors LGB individuals as compared to heterosexual counterparts. Identity centrality represents how much of a role identity plays in a person's life or how integral one's LGB identity is to their sense of self. Finally, identity affirmation refers to the extent to which individuals associate positive feelings with their sexual identity.

The main criticism of multidimensional models is that one cannot possibly measure every dimension of identity (Feldman \& Wright, 2013). Thus, any study may be limited by the dimensions that the researcher chooses and by the instruments available to measure identity in this way. Nevertheless, this approach is preferred for a number of reasons. Multidimensional models account for both positive and negative facets of identity. Many researchers treat positive and negative aspects of identity as if they are on a continuum (e. g., low levels of internalized homonegativity is positive), however, positive facets of identity are not merely the opposite of negative factors, as one may 
experience negative and positive feelings toward their identity simultaneously (Riggle et al., 2014). Instead, most researchers focus on one facet of identity, limiting the capacity for side by side comparison of these positive and negative aspects and their respective influences on one's mental health (Bregman, Malik, Page, Makynen, \& Lindahl, 2013). Thus far, identity literature in LGB individuals has focused largely on negative aspects, such as internalized homonegativity (Meyer, 2007). This neglect of the multidimensional nature of identity and its positive aspects means that the field has missed vital opportunities in determining potential internally-based sources of coping in LGB individuals. Another strength of the multidimensional approach is that it acknowledges one's identity and attitudes toward it can fluctuate. For example, an individual may have positive feelings toward their identity in one environmental context but moving to a less accepting location may affect their perspective negatively. Given the strengths of the multidimensional approach in addressing issues of diversity, contextual variations and their impact, and both positive and negative aspects of identity, it is important that the field move toward the study of identity as a multidimensional construct rather than a linear process that is relatively standard across individuals.

\section{Minority Identity and Mental Health}

Outside the context of discriminatory experiences, possessing a healthy sexual identity has been shown to be associated with a number of positive outcomes (Bosker, 2002), while other researchers have indicated no relationship between mental health and identity (D'Augelli, 2002). Mixed findings may be due to the U-shaped association between identity and mental health (Halpin \& Allen, 2004). When measured in a linear, stage-type approach, research indicates that individuals experience most distress during 
middle phases of identity formation, with less distress occurring at the beginning and later phases of identity development. It is thought that individuals at the start of the process are less aware of their identity, and thus do not struggle with it like those who are in the middle stages and have begun their identity exploration. Also, individuals who have reached the later stages have gained experience related to coming out, have developed social support, and are more settled in their identity, thus reducing distress associated with their sexual identity (Halpin \& Allen, 2004). This is supported by research indicating older LGB individuals (aged 60-91) report high levels of self-esteem and low levels of internalized homophobia, with the majority reporting good to excellent mental health that has improved with age (e.g., Grossman, D'Augelli, \& O'Connell, 2002; see Frederiksen-Goldsen \& Muraco, 2010 for a review of the literature on older LGB individuals). However, it is unclear how cumulative experiences of microaggressions over a long period of time impact one's mental health. Also, given that society is only recently shifting toward tolerance, older individuals developed their identities at a time when overt discrimination and violence were more prevalent, with many not coming out due to fears about society's response (Grossman, D'Augelli, \& O'Connell, 2002), and it is also not clear how this shift in attitudes impacts identity development. Evidence on the whole suggests that individuals with a more positive identity experience more positive outcomes. For example, Zoeterman \& Wright (2014) studied 109 ethnically diverse LGB individuals with an average age of 30 across the United States and found that positive LGB identity development was a full mediator of the relationship to mental health outcomes, in that being open to experience positively impacted LGB identity, and that identity was associated with improved outcomes. 
Another study found that lesbian women aged 16-24 who had integrated their sexual identity reported higher levels of self-esteem (Swann \& Spivey, 2004). Similar results have been seen in LGB youth, with those reporting higher identity integration scoring higher in psychological adjustment (Rosario, Schrimshaw, \& Hunter, 2011). A positive identity has also been associated with increased self-esteem in a sample of 192 LGB individuals aged 18-67 $(M=31.57, S D=10.11)$, and with reduced negative mental health outcomes (Feldman \& Wright, 2013). Identity strength was also shown to mediate the relationship between level of outness and mental health in this sample. Interestingly, when identity is controlled for, outness has a negative association with mental health (Feldman \& Wright, 2013), highlighting the distinction between outness and identity and lending credence to the importance of personal comfort with one's identity.

Having a positive identity is associated with reduced proximal stressors (Pachankis, 2008), described in minority stress theory (Meyer, 2003). These negative facets of identity, including internalized homonegativity, rejection sensitivity, and concealment are associated with a plethora of negative outcomes, including shame, guilt, and anxiety about being found out (Lane \& Wegner, 1995), psychological distress (Pachankis, 2008), depression and anxiety (DiPlacido, 1998), substance use disorders (Meyer \& Dean, 1998), and suicidality (Williamson, 2000). Minority stress theory suggests that having a positive identity reduces these negative components and can lead to increases in social support, as individuals who have concealed their identity and experience high rejection sensitivity are not likely to seek out social support (Kertzner, Meyer, Frost, \& Stirratt, 2009), which is an important source of resilience in LGB 
individuals. Thus, increasing the positive facets of identity may lead to reductions in these negative components.

Research with ethnic minority individuals has described ways that an individual's identity may function as a coping mechanism in order to explain the positive associations between identity strength and mental health outcomes described in this section. Individuals with a strong ethnic identity are more likely to be aware of the historical context of one's minority group, making it possible for the individual to differentiate between racist acts directed at the individual from those directed at the group they represent (Cross, 2005). Thus, they may be less likely to internalize the stigma perpetuated by such acts (Sellers \& Shelton, 2003). Furthermore, increased racial socialization prepares an individual to cope with experiences of discrimination (Hughes et al., 2006). An individual who has experienced more socialization is more likely to identify with their culture, strengthening one's ethnic identity. Thus, identity can serve as a buffer through this pathway. Additionally, the dimension of identity that involves group affiliation may alleviate some distress caused by discrimination, as the individual experiences a sense of belonging even in the face of rejection from the majority and can recognize that they are not alone in these experiences (Brondolo, Brady, Pencille, Beatty, \& Contrada, 2009).

\section{Identity as a Buffer against Negative Outcomes of Discrimination}

While the link between experiences of discrimination and negative outcomes has been established, little research has been conducted examining protective factors against the impact of these experiences in minority populations. Research examining the link between positive LGB identity and the negative impact of microaggressions is limited, 
but literature has explored the role of ethnic identity as a buffer against discriminatory experiences broadly, and identified it as a potential source of coping. These potential benefits are described in part by minority stress theory (Meyer, 2003), however, these benefits are largely limited to a discussion of how possessing a positive identity increases access to social support, and that this support then serves as a buffer. In terms of personal levels of coping, identity is seen as protective in that once an individual has developed "positive identity valence" in which they have gained self-acceptance and decreased internalized homophobia, one is less susceptible to the negative impact of discriminatory experiences (Meyer, 2003). This is related to a reduction in negative self-evaluation, which may help an individual to not internalize negative messages received through experiences of discrimination. Evidence for this association is presented below.

Ethnic identity has been studied from a multidimensional approach for decades longer than sexual identity (Sellers, Rowley, Chavous, Shelton, \& Smith, 1997). Group identification is an important piece of one's identity, and has been shown to buffer ethnic minority individuals against depressive symptoms in the face of discrimination (Bombay, Matheson, \& Anisman, 2010; Mossakowski, 2003; Whitbeck, Mansoso, Johnson, Hoyt, \& Walls, 2002). However, as discussed with sexual minority individuals, personal resources are important in the absence of group level coping or when this level of coping is not enough. For example, studies have yielded counter findings, indicating that group identification is not shown to serve as a buffer against the psychological distress caused by discriminatory experiences (Sellers \& Shelton, 2003). Personal identity-related variables may buffer against psychological distress when group identification is not serving as a protective factor. 
Research indicates that individuals with strong identification to their minority groups (known as racial centrality) perceive more discrimination (Sellers \& Shelton, 2003; Caldwell, Zimmerman, Bernat, Sellers, \& Notaro, 2002; Burrow \& Ong, 2010). This perception may be protective, because expectations of discrimination could lessen the impact of actual discrimination. However, frequent perception of discrimination may take a collective toll (Carter, 2007) and exacerbate the negative effects of discrimination (Bombay, Matheson, \& Anisman; 2010; Burrow \& Ong, 2010).

Whereas findings related to ethnic centrality are equivocal, racial ideology and public regard (the belief one has about how others view one's minority status) appear to buffer against the psychological distress experienced by those who perceive discrimination. Individuals who held the view that other groups perceive African Americans poorly were more protected against the negative impact of discrimination (Sellers \& Shelton, 2003). Similar research showed comparable buffering effects in youth samples (Sellers et al., 2006). While other studies have shown no association between public regard and distress caused by discrimination (Burrow \& Ong, 2010), this likely indicates that identity variables which make an individual more vigilant to experiences of discrimination may also protect them from the negative outcomes. Therefore, while identity may sometimes exacerbate experiences of discrimination, it may be protective as a result of the group identification it creates (Branscombe, Schmitt, \& Harvey, 1999), and through individual differences like centrality and ideology.

Affirmation, the extent to which an individual reflects positively on their sexual minority identity and group membership, is another facet of identity when assessed through the multidimensional approach. This facet has been understudied, with one study 
finding no association between affirmation and antisocial behaviors expressed by Asian Americans who have experienced discrimination (Park, Schwartz, Lee, Kim, \& Rodriguez, 2013). Higher identity affirmation has also been shown to buffer against reductions in self-esteem and increased depressive symptoms in Mexican American individuals (Romero \& Roberts, 2003; Umana-Taylor, Updegraff, \& Gonzales-Backen, 2011).

Ethnic identity commitment, an individual's feelings of attachment, belonging, and investment to their ethnic group, appears to be a promising line of research. Studies have shown that this facet serves as a buffer against the negative mental health consequences of covert discrimination (Torres, Yznaga, \& Moore, 2011) in Latino individuals. Similar results have been shown in Filipino Americans, in which identity salience, a construct comparable in definition to commitment, has been associated with decreased depressive symptoms in general (Mossakowski, 2003). Additionally, when lifetime and everyday perceived discrimination were entered into a regression model, ethnic identity commitment was shown to buffer the effects of discrimination on depressive symptoms. Ethnic identity showed buffering effects when both types of perceived discrimination were entered into a model together, and against both individually.

Private regard, one's own attitude toward their minority group and thus their own identity, has been shown to have a positive impact on individuals who have experienced discrimination when their private regard is positive. Individuals who score higher in this facet report fewer symptoms of anxiety and depression (Bynum, Best, Barnes, \& Burton, 2008). Furthermore, individuals who were higher in positive regard and experienced 
racism were less likely to display symptoms of anxiety, but private regard did not protect against depressive symptoms (Bynum et al., 2008). By contrast, Burrow and Ong (2010) found no relationship between private regard and negative outcomes; these differences may be due to differences in outcomes measured. Bynum et al. (2008) posit that this difference in anxiety and depressive symptoms may be related to whether the individual is able to draw upon their positive attitudes toward their ethnicity when racism triggers either an anxious or depressive reaction. Individuals lower in positive regard may view their minority status as a burden and thus be more likely to attribute their negative experiences to their ethnicity.

Assessing the buffering/exacerbating effects of identity is difficult due to inconsistencies in measurement of identity across studies and minority groups. One study of American Indians/Alaskan natives has shown a positive identity to be a buffer (Chae \& Walters, 2007). This study examined actualization, how much an individual has positively integrated their group and self-identities. The researchers found that the buffering effects of identity varied based on levels of actualization, meaning that individuals low in this facet had worse outcomes when faced with microaggressions, while those high in actualization showed no relationship between microaggressions and health outcomes. Higher levels of identity were associated with decreased likelihood of reporting pain.

\section{Sexual Minority Identity}

While findings in the ethnic identity literature have been mixed, the general trend is that positive facets of identity, such as commitment and centrality, serve a protective role. Very few studies have examined the association between positive factors of sexual 
identity and outcomes related to discrimination. There are studies focusing on negative aspects of identity, and the majority of these studies have examined these facets from a multidimensional perspective.

\section{LGB Identity as a Protective Factor}

Findings regarding the role of negative aspects of identity are important as they provide support for the minority stress model by elucidating mechanisms through which discriminatory experiences influence mental health. However, research is needed to identify positive factors and their protective potential. Lending credence to the importance of the development of a healthy identity, individuals who are still exploring their identities report greater psychological distress when faced with discrimination (Torres, Yznaga, \& Moore, 2011).

Indicating the increasing interest in a positive approach to identity assessment, researchers have recently created an instrument that assesses solely for these positive aspects (The LGB Positive Identity Measure; Riggle et al., 2014). This instrument is based on past research (Riggle \& Rostosky, 2012) that identified eight positives of possessing an LGB identity in a sample of 624 LGB individuals aged 15-75 ( $M=15.75$, $S D=12.50$ ), including increased self-awareness, gender fluidity, creating families of choice, not being defined by rules of sexuality, experiencing more empathy for others, becoming a positive role model, activist work, and being part of a community. In correlating their measure with the existing Lesbian and Gay Identity Scale (Mohr \& Fassingner, 2000), Riggle et al. (2014) concluded that there are indeed differences between positive and negative facets of identity, as some subscales did not correlate. The authors supported LGB identity as a multidimensional construct with a positive 
dimension that is important for mental health outcomes. Operational definitions and measurement of positive identity are varied but have now been addressed in several studies, albeit with differences in measurement.

Luhtanen (2002) studied factors associated with psychological distress and wellbeing in LGB participants recruited from the community in the Greater Buffalo area. A sample of 320 LGB participants aged 19-73 $(M=38.12, S D=10.33)$ completed measures of psychological well-being, measured using three scales, the Rosenberg (1965) Self-Esteem Scale, Satisfaction with Life Scale (Diener, Emmons, Larsen, \& Griffin, 1985), and the Center for Epidemiologic Studies Depression Scale (Radloff, 1977). They also assessed Visibility (using a scale modified from Weinberg \& Williams, 1974), Involvement in LGB Culture (measured with two questions), Perceived Acceptance (in which individuals rated acceptance by various individuals in their lives), Rejection of Negative Stereotypes (assessed with five researcher generated items), and Positivity of LGB Identity (assessed with four researcher generated items). Results indicated that measures of visibility, involvement with other LGB individuals, acceptance by family members, rejection of negative stereotypes, and positive LGB identity all demonstrated significant positive relationships with well-being (negative relationship with depression measure). LGB identity was also significantly associated with self-esteem in women, while LGB identity and involvement with other LGB individuals were significantly associated with life satisfaction in women. Positive LGB identity was significantly associated with life satisfaction in men. Positive LGB identity and rejection of negative stereotypes were shown to predict depression scores when entered into a regression model, however, the nature of the relationship is unclear due to the data being cross- 
sectional. Of all the variables in this regression, LGB identity was the strongest predictor of the various measures of psychological well-being. A limitation of this study was the absence of validated or established measures, highlighting the need for consistency in the measurement of identity, as it is difficult to tell whether results would generalize. While the study was published in 2002, data were collected in 1994 (over 20 years ago), thus these measures may not have existed. Additionally, while the age of Luhtanen's (2002) sample varied greatly (19-73), age was controlled for in analyses, thus it is unclear whether any differences existed in well-being across age cohorts. Despite these limitations, the findings of this study support the association between positive identity and well-being, which may suggest that developing a positive identity could be one way of coping with negative experiences.

Discrimination is experienced at the systems level, with antigay politics representing one form of such discrimination. In a study by Russell \& Richards (2003), 316 LGB individuals, aged 14-67 $(M=35.7, S D=14-67)$, recruited through LGB gatherings and snowball/word-of-mouth techniques completed a 130-item measure regarding their experiences with Amendment 2, an antigay amendment passed in Colorado which legalized discrimination against LGB individuals. The items assessed negative experiences and sources of coping related to the amendment. A factor analysis was conducted to explore themes related to resilience and stressors when faced with antigay politics. Stressor themes were encounters with homophobia (feelings of shock that such legislation would pass), community divisions (disappointment with response within the LGB community), making sense of danger (feeling as though beliefs about the safety of the world were inaccurate), failed witnessing (family members did not 
acknowledge negativity of the amendment), and internalized homonegativity (selfdirecting negative messages associated with the political campaign). Themes related to sources of resilience included movement perspective (seeing the amendment as part of a larger battle for LGB rights), confronting internalized homonegativity (examination of their own lives and how they are affected by homonegativity), expression of affect (using emotions purposefully), successful witnessing (validation by close friends and family), and LGB community (seeking social support).While these themes were not tested with separate validated measures, it appears that positive feelings toward one's identity and social support are protective factors in the face of systemic discrimination.

Sexual identity has also been studied as a construct modified from ethnic identity literature, with one study (Fingerhut, Peplau, \& Gable, 2010) using a modified version of the Multigroup Ethnic Identity Measure (MEIM; Phinney, 1992) to assess gay identity in a national online sample of 449 predominantly White LG individuals aged 18-76 ( $M=$ $32.86, S D=12.08)$. As expected, discrimination and perceived stigma were positively associated with depression, while individuals scoring higher on the modified MEIM indicated lower levels of depression. Furthermore, those higher on the MEIM endorsed increased levels of discrimination but less perceived stigma. The authors predicted that gay identity would buffer against the negative impact of these minority stressors, but found that gay identity was not associated with depression when interacting with discrimination. However, in individuals with lower MEIM scores (but not those higher in identity based on a cutoff score), increased levels of perceived stigma were predictive of depressive symptoms. The authors posit that identity can serve a protective role despite their mixed findings. The lack of significance in relation to discrimination was counter to 
studies that have shown that such a relationship exists in ethnic minority individuals (Neblett, Shelton, \& Sellers, 2004). However, these findings may be influenced by the use of measures (including identity and report of discrimination) that were modified to fit the LG experience. Only one study has examined the links between microaggressions and LGB identity as a protective factor specifically. Woodford, Kulick, Sinco, \& Hong (2014) examined the role of self-acceptance in the relationship between heterosexism and psychological distress. A sample of 417 lesbian, gay, bisexual, transgender, and queer (LGBTQ) students (mean age $=24$ years) completed measures of microaggressions, as measured by the LGBTQ Microaggressions on Campus Scale (Woodford, Chonody, Kulick, Brennan, \& Renn, 2015), self-esteem, assessed using the Rosenberg Self-Esteem Scale (Rosenberg, 1965), LGBTQ pride, measured using an adapted version of the gay affirmation subscale of the Internalized Homonegativity Inventory (Mayfield, 2001), and psychological distress, measured by the Generalized Anxiety Disorder-7 Scale (Spitzer, Kroenke, Williams, \& Lowe, 2006) and the Perceived Stress Scale (Cohen, Kamarck, \& Mermelstein, 1983). Results indicated that increased exposure to microaggressions resulted in higher overall distress. However, self-acceptance mediated the relationship, indicating that the higher an individual scores in self-acceptance, the lower their psychological distress. While this study suggests that positive facets of identity may serve as a protective factor against the negative impact of microaggressions, it only examines one facet, LGBTQ pride, and thus provides a limited view of the protective potential of the multidimensional identity. 


\section{Study Aims and Hypotheses}

While findings are limited and mixed, it appears that possessing a positive LGB identity is a source of coping in sexual minority individuals. The use of measures of LGB identity that have not been validated and focus on one identity facet at a time may account for the mixed findings. Additionally, very little research has been conducted examining LGB identity and experiences of microaggressions, limiting our understanding. The relationship between positive and negative facets of identity is also unclear. The present study addresses some of the limitations in the existing literature by proposing that identity be measured from a multidimensional approach, as measured by the Lesbian, Gay, and Bisexual Identity Scale (Mohr \& Kendra, 2011) that permits comparison of the impact of various identity facets on mental health outcomes. A primary purpose of the study will be to extend the assessment of LGB identity as a resource for coping with negative mental health symptoms associated with microaggressions.

\section{Aim 1. Examine Identity from a Multidimensional Approach}

Some researchers suggest that any collective identities are multidimensional (Ashmore, Deaux, \& McLaughlin, 2004) and thus should be measured as such. Recently developed measures reflect this shift in identity measurement (Mohr \& Kendra, 2011; Riggle et al., 2014), however, the study of identity has not yet fully embraced this shift. Also, the link between negative facets of identity and positive factors is unclear. Studies have shown that these factors may not be correlated, indicating that one may have high levels of both positive and negative factors. Thus, the first aim of the study is to examine identity from a multidimensional approach in order to determine the relationship between negative identity dimensions and positive identity dimensions. 
Hypothesis 1. It is hypothesized that each of the three positive identity factors will be negatively correlated with five negative identity factors.

\section{Aim 2. Examine the Role of Positive Identity in Buffering against}

\section{Microaggressions}

Microaggressions are distressing for hidden minority individuals as they face the prospect of "outing" themselves in order to confront the perpetrator of the microaggression. Individuals who do not possess a positive identity may not be comfortable "outing" themselves in order to face the individual, and thus they become further silenced. However, those who are secure in their identity and its positive qualities may not be as distressed by the prospect of coming out in order to confront the microaggression. Furthermore, individuals who have a healthy sense of identity may more readily recognize the offensive nature of the microaggression and the need to cope, spending less time questioning whether they experienced a microaggression and can move into deciding on their coping reaction more quickly, whether the reaction is one of the behavioral, cognitive, or emotional strategies previously mentioned (Nadal et al., 2011b). Additionally, individuals with a more positive identity may be more likely to have a well-developed group identity, thus recognizing sooner that other individuals face similar experiences. Research has shown that these experiences of common humanity are helpful in reducing distress (Leary, Tate, Adams, Batts-Allen, \& Hancock, 2007).

Hypothesis 2. Positive identity will serve as a protective factor in the face of microaggressions, with those with higher scores in each of the three positive identity subscales reporting reduced symptoms of anxiety and depression. Individuals with lower 
positive identity scores are expected to have higher levels of anxiety and depression when faced with microaggressions.

\section{Aim 3. Examine Unique Contribution of Identity, Social Support, and}

\section{Outness}

One issue that arises when examining identity is differentiating the effects of positive identity from outness and the social support that it leads to upon coming out. Research has established the importance of social support in buffering against the negative impact of discrimination as one feels less isolated and recognizes that these experiences are common to other individuals. An aim of this study is to create a model examining the unique contributions of outness, positive identity, and social support.

Hypothesis 3. Outness, positive identity, and social support will demonstrate a buffering effect against symptoms of anxiety and depression when experiencing microaggressions. Positive identity will significantly contribute unique variance in buffering against the negative impact of microaggressions. 


\section{CHAPTER II}

\section{METHODS}

\section{Participants}

The sample in the current study consisted of 135 college students at the University of Louisville. Specific inclusion criteria were that participants would be over 18 years of age and identify as lesbian, gay, or bisexual. College-aged participants were chosen for this study because important aspects of identity development occur during these years, with research indicating individuals self-identify as LGBTQ+ in late teenage years and have their first intimate relationships during their college years (Martos, Nezhad, \& Meyer, 2015). The sample was recruited through the online university research database, word-of-mouth methods, and posting flyers at the LGBT Center on campus. The study was described in recruitment materials as an investigation of resilience factors in LGB individuals when faced with discrimination. The majority of participants identified as bisexual $(\mathrm{n}=105)$. All individuals were at least 18 years old, with ages ranging from $18-41(M=20.42, S D=3.82)$. One hundred and one $(74.8 \%)$ participants identified as female, $113(83.7 \%)$ were single, and 81 identified as European American (60\%). See Table 1 for complete demographics. 
Table 1

Demographic Information

\begin{tabular}{|c|c|c|}
\hline \multicolumn{2}{|l|}{ Characteristic } & \multirow{2}{*}{$\begin{array}{l}\text { Frequency (\%) } \\
101(74.8)\end{array}$} \\
\hline Gender Identity & Female & \\
\hline & Male & $27(20)$ \\
\hline & Non-binary/third gender & $3(2.2)$ \\
\hline & Prefer to self-describe & $3(2.2)$ \\
\hline & Prefer not to say & $1(.7)$ \\
\hline \multirow[t]{6}{*}{ Ethnicity } & African American & $13(9.6)$ \\
\hline & Asian American & $11(8.1)$ \\
\hline & Hispanic/Latino & $8(5.9)$ \\
\hline & European American & $81(60.0)$ \\
\hline & Native American & $1(.7)$ \\
\hline & Other/Multiracial & $21(15.6)$ \\
\hline \multirow[t]{3}{*}{ Sexual Orientation } & Lesbian & $15(11.1)$ \\
\hline & Gay & $15(11.1)$ \\
\hline & Bisexual & $105(77.8)$ \\
\hline \multirow[t]{4}{*}{ Relationship Status } & Married/partnered & $18(13.3)$ \\
\hline & Divorced & $3(2.2)$ \\
\hline & Separated & $1(.7)$ \\
\hline & Single & $113(83.7)$ \\
\hline \multirow[t]{12}{*}{ Household Income } & Less than $\$ 10,000$ & $18(13.3)$ \\
\hline & $\$ 10,000-\$ 19,999$ & $15(11.1)$ \\
\hline & $\$ 20,000-\$ 29,999$ & $11(8.1)$ \\
\hline & $\$ 30,000-\$ 39,999$ & $10(7.4)$ \\
\hline & $\$ 40,000-\$ 49,999$ & $10(7.4)$ \\
\hline & $\$ 50,000-\$ 59,999$ & $9(6.7)$ \\
\hline & $\$ 60,000-\$ 69,999$ & $10(7.4)$ \\
\hline & $\$ 70,000-\$ 79,999$ & $10(7.4)$ \\
\hline & $\$ 80,000-\$ 89,999$ & $9(6.7)$ \\
\hline & $\$ 90,000-\$ 99,999$ & $6(4.4)$ \\
\hline & $\$ 100,000-\$ 149,999$ & $16(11.9)$ \\
\hline & More than $\$ 150,000$ & $11(8.1)$ \\
\hline
\end{tabular}

\section{Measures}

Lesbian, Gay, Bisexual Identity Measure (LGBIS; Mohr \& Kendra, 2011)

The LGBIS (Mohr \& Kendra, 2011) is a multidimensional measure of LGB identity that assesses for eight dimensions of identity: Concealment Motivation, Identity Uncertainty, Internalized Homonegativity, Difficult Process, Acceptance Concerns, 
Identity Superiority, Identity Centrality, and Identity Affirmation. Concealment Motivation assesses the degree to which a person is cautious about revealing their LGB identity or maintaining privacy. Identity Uncertainty refers to ambiguity regarding one's identity. Internalized Homonegativity assesses one's own rejection of and negative feelings toward their identity. Difficult Process addresses hardship in one's development and acceptance of their LGB identity. Acceptance Concerns relates to one's fear that their identity will not be embraced or will be judged by others. Identity Superiority examines one's preference for LGB individuals over heterosexual individuals. Identity Centrality examines how integral one's LGB identity is to their sense of self. Identity Affirmation measures general positive attitudes toward one's LGB identity. The LGBIS has strengths over other measures of identity, including the capacity to assess bisexual individuals, yielding of subscale scores, application to men and women, conciseness in terms of number of items, relation to minority stress processes, and assessment of LGB identity from a multidimensional perspective. A confirmatory factor analysis of the scale yielded eight factors that demonstrated good fit $(\mathrm{CFI}=.94)$. The LGBIS also yields a total Negative Identity Subscale created by totaling all five negative identity subscales and reverse scoring Identity Affirmation to reach a total average score of these six subscales. The LGBIS has been shown to be reliable, with alpha scores of each subscale ranging from .76 to .89 (Mohr \& Kendra, 2011). Validity was established through comparison with other validated measures, including the Ego-Dystonic Homosexuality Scale (Martin \& Dean, 1987), an adapted version of the Multigroup Ethnic Identity Measure (Phinney, 1992), the Collective Self-Esteem Scale (Luhtanen \& Crocker, 1992), and a subscale of the Outness Inventory (Mohr \& Fassinger, 2000). The LGBIS was significantly 
correlated with these measures in the hypothesized directions (Mohr \& Kendra, 2011). The LGBIS demonstrated good reliability in this sample, with Cronbach's alphas for the subscales ranging from .70 to .90 , with Difficult Process demonstrating lowest reliability and Identity Affirmation demonstrating the highest reliability.

Homonegative Microaggressions Scale (HMS; Wright \& Wegner, 2012)

The HMS is a 45-item measure that was used to capture the experience of microaggressions in LGB individuals. Items assess common microaggressions, such as "how often have people conveyed that it is your choice to be gay" and "How often have people acted as if you have not come out." Scoring of the HMS yields a total score and four subscales based on the type of microaggression, including Assumed Deviance, Second-Class Citizen, Assumptions of Gay Culture, and Stereotypical Knowledge and Behavior. Responses are rated on a six point Likert-type scale ranging "hardly ever/never/not at all" to "constantly/a great deal," with an option of "not applicable." This measure demonstrated excellent reliability $(\alpha=.95)$ in a sample of 120 predominantly White LGB individuals from the community with a mean age of $34(S D=$ 11.6; Wright \& Wegner, 2012). Construct validity was established through examining correlations between the HMS and measures of prejudice, perceived discrimination, and oppressive situations. Criterion-related validity was established by examining correlations between the HMS and scales examining self-esteem and identity, with results matching hypothesized associations (Wright \& Wegner, 2012). The total score demonstrated excellent reliability in this sample $(\alpha=.94)$. 


\section{Beck Anxiety Inventory (BAI; Beck, 1990)}

The BAI is a widely used instrument designed to discriminate anxiety from depression, consisting of 21-items describing common symptoms of anxiety. Anxiety was assessed as one mental health factor associated with microaggressions, as past research has demonstrated a relationship between distal stressors and anxiety symptoms. The BAI has been shown to be internally consistent ( $\alpha=.94$; Fydrich, Dowdall, \& Chambless, 1992), and showed excellent reliability in the current sample $(\alpha=.95)$.

Beck Depression Inventory-II (BDI-II, Beck, Steer, \& Brown, 1996)

Participants also completed the BDI-II, a widely used 21-item self-report measure of depressive symptoms with high internal consistency $(\alpha=.90$; Wang \& Gorenstein, 2013). Depression, as assessed by the BDI-II, was evaluated as the other associated mental health factor, given the relationship that has been demonstrated between discriminatory experiences and symptoms of depression. The BDI-II showed excellent reliability in this sample $(\alpha=.94)$.

Medical Outcomes Study Social Support Survey (MOS; Sherbourne \& Stewart, 1991)

The MOS was administered to assess for social support. It consists of 19 items and yields four subscales, including Emotional, Tangible, Affectionate, and Positive Social Interaction, as well as a total score. It has been shown to demonstrate good reliability $(\alpha=.89)$ in LGBT individuals (Balsam, Molina, Beadnell, Simoni, \& Walters, 2011). The MOS demonstrated excelled internal consistency in the current sample $(\alpha=$ $.96)$. 
Outness Inventory (OI; Mohr \& Fassinger, 2000)

The $\mathrm{OI}$ is an 11-item measure of the degree to which one has revealed their sexual orientation. It assesses various domains in which an individual may come out, yielding three subscale scores including Outness to Family, Religion, and the World. The OI also yields a total score. Outness is related to identity, in that those who possess a positive sense of their identity may be more likely to come out. In coming out, individuals gain access to social support which has been shown to be a protective factor against discrimination. Thus, it is important to assess this in order to differentiate among identity, outness, and social support. Internal consistency for this measure ranges from .74 to .97 (Mohr \& Fassinger, 2000; Feldman \& Wright, 2013); the alpha was .91 in this study.

\section{Procedure}

Given the paucity of research in this area, self-report data was used to form a foundation for future research. Data was gathered online through the use of the Qualtrics survey platform. Individuals provided consent to participate in the online study by reading a consent form and selecting whether or not they provided consent to continue. Those who did not provide consent were sent to a "thank you" page at the end of the study. Individuals who consented then completed the previously mentioned self-report measures. Participation was anticipated to last no longer than one hour. Upon completion, participants were provided with contact information for the primary researcher, Ghazel Tellawi. 


\section{CHAPTER III}

\section{RESULTS}

\section{Power Analysis}

An a priori power analysis was conducted using $\mathrm{G}^{*}$ Power based on the largest analysis (Aim 3) to determine adequate sample size. This analysis included a linear multiple regression (fixed model, $\mathrm{R}^{2}$ deviation from zero) with seven independent variables (microaggressions, positive identity, social support, outness, and three interaction variables created by multiplying microaggressions with each of the three listed proposed protective variables. Effect size was entered at .2 and power set at .95 . This indicated 117 participants were necessary to have adequate power. Past research has also indicated roughly 15 participants are necessary per independent variable to achieve adequate power (Stevens, 1996), indicating 135 participants were necessary for this aim. In order to account for potential outliers and data errors, sample size was set to the more conservative 135 participants.

\section{Sample Characteristics}

Prior to conducting analyses for hypotheses, study variables were explored, and where appropriate, means, standard deviations, and ranges were calculated. These statistics are reported in full in Table 2. Key measures were compared to previously 
established norms. When compared to Mohr \& Kendra (2011), the study in which the LGBIS was validated, the current sample's average scores across the five negative identity scales was 0.68 higher than Mohr \& Kendra's (2011) sample means, indicating higher levels of negative identity in the current sample. On the positive identity scales, the current sample's mean score was .07 higher than the mean score of the validation study sample on Identity Superiority, 0.62 lower on Identity Affirmation, and 0.50 lower on Identity Centrality. One-sample t-tests of the differences between the current sample's LGBIS scores and Mohr and Kendra's (2011) sample indicated significant differences on all subscales except Identity Superiority. The current sample demonstrated similar variability with the aforementioned sample. Average scores on the HMS were somewhat higher in this sample than Wegner (2014). Specifically, the current sample mean was 0.11 higher than Wegner (2014)'s sample mean for the HMS total score. A one-sample ttest revealed no significant difference between these scores.

Table 2

Study Variable Descriptives

\begin{tabular}{lllll}
\hline Study Variable & Subscale & Mean & SD & Range \\
\hline Lesbian, Gay, & Negative Identity & 3.06 & 0.82 & $1.22-5.14$ \\
Bisexual Scale & Acceptance Concerns & 3.64 & 1.22 & $1.0-6.0$ \\
& Concealment Motivation & 3.81 & 1.28 & $1.0-6.0$ \\
& Identity Uncertainty & 2.80 & 1.13 & $1.0-5.5$ \\
& Internalized Homonegativity & 2.38 & 1.22 & $1.0-6.0$ \\
& Difficult Process & 3.37 & 1.15 & $1.0-6.0$ \\
& Identity Superiority & 2.06 & 1.10 & $1.0-6.0$ \\
& Identity Affirmation & 4.51 & 1.15 & $1.0-6.0$ \\
& Identity Centrality & 3.60 & .99 & $1.0-6.0$ \\
Homonegative & Total Score & 2.64 & .76 & $1.2-6.0$ \\
Microaggressions & Assumed Deviance & & & \\
Scale & Second Class Citizen & 2.18 & .90 & $1.0-6.0$ \\
& Assumptions of Gay Culture & 2.66 & .82 & $1.0-6.0$ \\
& Stereotypical Knowledge and Behaviors & 3.00 & .92 & $1.0-6.0$ \\
& & 2.48 & 1.11 & $1.0-6.0$
\end{tabular}




\begin{tabular}{lllll} 
Survey of Social & Total Score & 3.80 & .87 & $1.72-5.0$ \\
Support & Emotional & 3.76 & .96 & $1.57-5.0$ \\
& Tangible & 3.72 & 1.07 & $1.0-5.0$ \\
& Affectionate & 3.83 & 1.19 & $1.0-5.0$ \\
& Positive Social Interaction & 4.01 & .89 & $1.67-5.0$ \\
Outness & Overall & 3.99 & 2.02 & $1.0-7.58$ \\
Inventory & Family & 4.11 & 2.06 & $1.0-7.25$ \\
& World & 3.61 & 2.04 & $1.0-8.0$ \\
& Religion & 4.23 & 3.14 & $1.0-8.0$ \\
Beck Depression & & 18.27 & 12.66 & $0.0-56.0$ \\
Inventory-II & & & & \\
Beck Anxiety & & 22.13 & 14.29 & $0.0-61.0$ \\
Inventory & & & & \\
\hline
\end{tabular}

\section{Demographic Differences}

Where appropriate, correlational analyses were conducted to determine if demographic variables were significantly associated with relevant study variables. These results indicated age was significantly correlated with the Outness Inventory total score $(r$ $=.190, p=.027)$, LGBIS Identity Uncertainty $(r=. .218, p=.011)$, and LGBIS Identity Superiority $(r=-.172, p=.046)$. Household income was not significantly correlated with any study variables.

Given unequal sample sizes, Kruskal Wallis Tests were conducted to determine whether there were significant differences in study variables across categorical demographic variables, including gender, sexual orientation, ethnicity, and income. Results indicated significant differences across sexual orientation on the LGBIS subscales of Concealment Motivation, $\chi 2(2, N=135)=9.56, p=.008$, Identity Uncertainty, $\chi 2(2, N=135)=23.84, p<.001$, Internalized Homonegativity, $\chi 2(2, N=$ $135)=6.85, p=.033$, Identity Affirmation, $\chi 2(2, N=135)=11.36, p=.003$, Identity Centrality, $\chi 2(2, N=135)=9.21, p=.010$, and the overall Negative Identity Subscale, $\chi$ 
$2(2, N=135)=14.51, p=.001$. There were also differences in the Outness Inventory total score across sexual orientations, $\chi 2(2, N=135)=12.58, p=.002$. Because of unequal sizes of the three sexual orientation groups, Scheffe post hoc criterion for significance was used to determine which groups differed on these variables. These results indicated that the average score for Concealment Motivation was significantly higher for bisexual individuals $(M=3.97, S D=1.24)$ than lesbian participants $(M=$ 2.91, $S D=1.24)$ but not gay participants $(M=3.53, S D=1.23)$. Identity Uncertainty was also significantly higher in bisexual participants $(M=3.04, S D=1.03)$ than both lesbian $(M=2.10, S D=1.17)$ and gay $(M=1.80, S D=0.93)$ participants. Bisexual individuals $(M=2.50, S D=1.23)$ also scored significantly higher than lesbian participants $(M=1.62, S D=0.64)$ on Internalized Homonegativity. Identity Affirmation scores were significantly lower for bisexual participants $(M=4.35, S D=1.14)$ than lesbian participants $(M=5.33, S D=0.63)$. Lesbian individuals $(M=4.43, S D=1.14)$ scored significantly higher on Identity Centrality than bisexual individuals $(M=3.46, S D$ $=0.93)$. Lesbian individuals $(M=2.39, S D=0.68)$ scored significantly lower on the Negative Identity Subscale than bisexual participants $(M=3.21, S D=0.81)$. Bisexual individuals $(M=3.67, S D=1.99)$ also scored significantly lower than lesbian participants $(M=5.24, S D=1.67)$ on the Outness Inventory. Means and standard deviations for study variables across each sexual orientation category are shown in Table 3. In sum, the general trend in these finding was that bisexual participants had higher negative facets of identity and were less likely to be out than participants who identified as gay or lesbian. 
Kruskall-Wallis Tests were conducted to determine gender differences. These results indicated significant group differences on the BDI-II, $\chi 2(4, N=135)=11.41, p=$ .022. One person chose the option "prefer not to say" for gender identity, resulting in a category containing less than two participants. In order to conduct post hoc analyses, groups must contain two or more participants. Thus, this individual was removed for the purposes of this analysis only. Post hoc analyses using Scheffe's criterion for significance indicated individuals who identified as non-binary/third gender $(M=43.00, S D=4.58)$ scored significantly higher on the BDI-II than male $(M=15.33, S D=11.22)$ and female participants $(M=18.18, S D=12.41)$. The individual removed from this analysis scored a 7 on the BDI-II and 14 on the BAI. No significant ethnic differences were found for any of the study variables.

Table 3

Study Variable Descriptives by Sexual Orientation

\begin{tabular}{lllll}
\hline & & Lesbian & Gay & Bisexual \\
\hline Study Variable & Subscale & Mean (SD) & Mean (SD) & Mean (SD) \\
\hline Lesbian, Gay, & Negative Identity & $2.39(.68)$ & $2.84(.71)$ & $3.21(.81)$ \\
Bisexual Scale & Acceptance Concerns & $3.20(1.50)$ & $3.76(1.10)$ & $3.68(1.19)$ \\
& Concealment Motivation* & $2.91(1.24)$ & $3.53(1.23)$ & $3.97(1.24)$ \\
& Identity Uncertainty* & $2.10(1.17)$ & $1.80(.93)$ & $3.04(1.03)$ \\
& Internalized Homonegativity* & $1.62(.64)$ & $2.27(1.36)$ & $2.50(1.23)$ \\
& Difficult Process & $2.84(1.41)$ & $3.44(1.20)$ & $3.43(1.10)$ \\
& Identity Superiority & $2.16(1.40)$ & $2.27(.75)$ & $2.02(1.10)$ \\
& Identity Affirmation* & $5.33(.63)$ & $4.78(1.23)$ & $4.35(1.15)$ \\
Homonegative & Identity Centrality* & $4.43(1.14)$ & $3.76(.83)$ & $3.46(.93)$ \\
Microaggressions & Total Score* & $2.51(.85)$ & $2.54(.69)$ & $2.67(.76)$ \\
Scale & Assumed Deviance & $1.96(.75)$ & $2.10(1.04)$ & $2.22(.90)$ \\
& Second Class Citizen & $2.56(.74)$ & $2.55(.74)$ & $2.68(.85)$ \\
& Assumptions of Gay Culture & $2.79(1.27)$ & $2.76(.80)$ & $3.06(.87)$ \\
Survey of Social & Total Score & $2.59(1.04)$ & $2.91(.93)$ & $2.40(1.14)$ \\
Support & Emereotypical Knowledge & & & \\
& and Behaviors & $4.00(1.07)$ & $4.01(.88)$ & $3.74(.84)$ \\
& Emotional & $3.95(1.09)$ & $3.88(1.04)$ & $3.71(.94)$
\end{tabular}




\begin{tabular}{lllll} 
& Tangible & $4.01(1.27)$ & $4.11(1.00)$ & $3.62(1.04)$ \\
& Affectionate & $3.87(1.50)$ & $4.04(1.17)$ & $3.80(1.15)$ \\
Outness & Positive Social Interaction & $4.22(1.02)$ & $4.16(.81)$ & $3.97(.89)$ \\
Inventory & Overall* & $5.24(1.67)$ & $4.96(1.82)$ & $3.67(1.99)$ \\
& Family & $4.82(1.73)$ & $4.80(1.83)$ & $3.91(2.10)$ \\
& World & $5.12(1.72)$ & $4.62(1.67)$ & $3.26(2.00)$ \\
Beck Depression & Religion & $5.80(3.03)$ & $5.47(3.16)$ & $3.83(3.07)$ \\
Inventory-II & & $20.93(16.48)$ & $16.87(11.29)$ & $18.10(12.29)$ \\
Beck Anxiety & & & & \\
Inventory & & $21.53(13.92)$ & $18.00(10.41)$ & $22.81(14.81)$ \\
\hline
\end{tabular}

*Significant group differences based on Kruskal Wallis comparisons.

\section{Aim 1: Positive and Negative Identity}

Hypothesis 1 predicted that positive and negative facets of identity, as measured by the LGBIS, would be negatively correlated. The LGBIS yields eight subscales, with five assessing negative facets and three measuring positive aspects. Prior to conducting Pearson bivariate correlations, assumptions of normality, presence of outliers, linearity, and homoscedasticity were tested for all LGBIS subscales. As the sample size was greater than 50 but less than 300, z-skew scores for each variable were compared to the absolute z-value of 3.29 in order to determine normality (Kim, 2013). At this value, all LGBIS subscales met assumptions of normality. Since no values were three standard deviations higher or lower than the mean, outliers were not removed from analyses. Assumptions of homoscedasticity were also met. Pearson bivariate correlation analyses yielded mixed findings across the subscales. Identity Superiority demonstrated a significant positive correlation with Acceptance Concerns $(r=.203, p=.018)$ but no other negative identity subscales (see Table 4). Identity Centrality demonstrated significant correlations with two of five negative identity subscales, although not in the same direction: it was positively correlated with Acceptance Concerns $(r=.254, p=$ 
$.003)$ and negatively correlated with Internalized Homonegativity, $(r=-.240, p=.005)$.

Identity Affirmation was significantly correlated with four of the five negative identity

subscales, and demonstrated the strongest correlation with Internalized Homonegativity, $r$

$=-.637, p<.001$. Identity Affirmation was also significantly correlated with Difficult

Process $(r=-.225, p=.009)$, Identity Uncertainty $(r=-.267, p=.002)$, and Concealment

Motivation $(r=-.434, p<.001)$.

Table 4

LGBIS Subscale Pearson Bivariate Correlations

\begin{tabular}{llllllll}
\hline LGBIS Subscale & $\begin{array}{l}\text { Identity } \\
\text { Superiority }\end{array}$ & $\begin{array}{l}\text { Identity } \\
\text { Affirmation }\end{array}$ & $\begin{array}{l}\text { Identity } \\
\text { Centrality }\end{array}$ & $\begin{array}{l}\text { Acceptance } \\
\text { Concerns }\end{array}$ & $\begin{array}{l}\text { Concealment } \\
\text { Motivation }\end{array}$ & $\begin{array}{l}\text { Identity } \\
\text { Uncertainty }\end{array}$ & $\begin{array}{l}\text { Internalized } \\
\text { homonegativity }\end{array}$ \\
\hline Identity Superiority & & & & & & \\
Identity Affirmation & .157 & & & & & \\
Identity Centrality & $.359^{* *}$ & $.478^{* *}$ & & & & \\
Acceptance Concerns & $.203^{*}$ & -.126 & $.254^{* *}$ & & & \\
Concealment Motivation & -.092 & $-.434^{* *}$ & -.161 & $.506^{* *}$ & & \\
Identity Uncertainty & .143 & $-.267^{* *}$ & -.108 & $.239^{* *}$ & $.342^{* *}$ & & \\
Internalized homonegativity & .010 & $-.637^{* *}$ & $-.240^{* *}$ & $.248^{* *}$ & $.500^{* *}$ & $.435^{* *}$ & $.311^{* *}$ \\
Difficult Process & .122 & $-.225^{* *}$ & .101 & $.609^{* *}$ & $.499^{* *}$ & $.320^{* *}$ \\
\hline
\end{tabular}

Note: *Correlation is significant at the 0.05 level (2-tailed).

**Correlation is significant at the 0.01 level (2-tailed)

\section{Aim 2: Microaggressions, Identity, and Mental Health}

The second hypothesis predicted that positive identity will serve as a buffer against microaggressions, with those scoring higher in each of the three positive identity subscales demonstrating lower levels of depression and anxiety than participants who score lower in positive identity when dealing with microaggressions. None of the three positive identity subscales were significantly correlated with the BAI. Only Identity Centrality was significantly correlated with the BDI-II $(r=.197, p=.022)$. However, this significant association was in the reverse of the hypothesized direction, indicating that as Identity Centrality increases, symptoms of depression increase. The HMS was 
significantly correlated in the expected direction with both the BAI $(r=.204, p=.018)$ and the BDI-II $(r=.222, p=.010)$.

To test this hypothesis, regression analyses were conducted with depression or anxiety as the dependent variable. For each, microaggressions was entered into the equation first, followed by an LGBIS positive identity subscale. The buffering effect was tested by entering the interaction term last into the regression model. In order to create interaction terms, respective mean scores on the HMS and each of the three positive LGBIS subscales were subtracted from the total scores to center the variables at the mean. These variables were then multiplied (e.g., HMS*Identity Superiority) to create interaction variables. Three separate regression analyses were conducted to examine depression as the dependent variable, with Identity Superiority tested first. The overall model accounted for significant variance in the BDI-II, $F(3,131)=3.58, p=.016$, however, only the HMS demonstrated a significant effect $(\beta=0.233, p=.009)$ when the independent variables were examined individually. These findings do not support the hypothesis that Identity Superiority will function as a buffer against the impact of microaggressions on depressive symptoms.

Centrality was examined next, with results indicating the overall model including Identity Centrality, the HMS, and the Identity Centrality and HMS interaction term as independent variables accounted for significant variance in the BDI-II, $F(3,131)=$ $5.38, p=.002$, with an $R^{2}=.110$. The HMS $(\beta=0.209, p=.002)$ and the interaction term $(\beta=0.198, p=.047)$ both accounted for significant variance in BDI-II scores, while Identity Centrality $(\beta=0.150, p=.076)$ did not exhibit a significant main effect. In order to further understand the relationship between the HMS and Identity Centrality, both 
were dichotomized at the median and their relationship with depressive symptoms was graphed. See Figure 1 for a graph of this relationship. Contrary to the buffering hypothesis, it appears Identity Centrality interacts significantly with the HMS to exacerbate the negative impact of experiences of homonegative microaggressions. Specifically, it appears those higher in Identity Centrality also score higher on the BDI-II, and this relationship becomes more pronounced in individuals who report more experiences of microaggressions.

Figure 1.

Interaction between Microaggressions and Identity Centrality with Respect to Depressive Symptoms

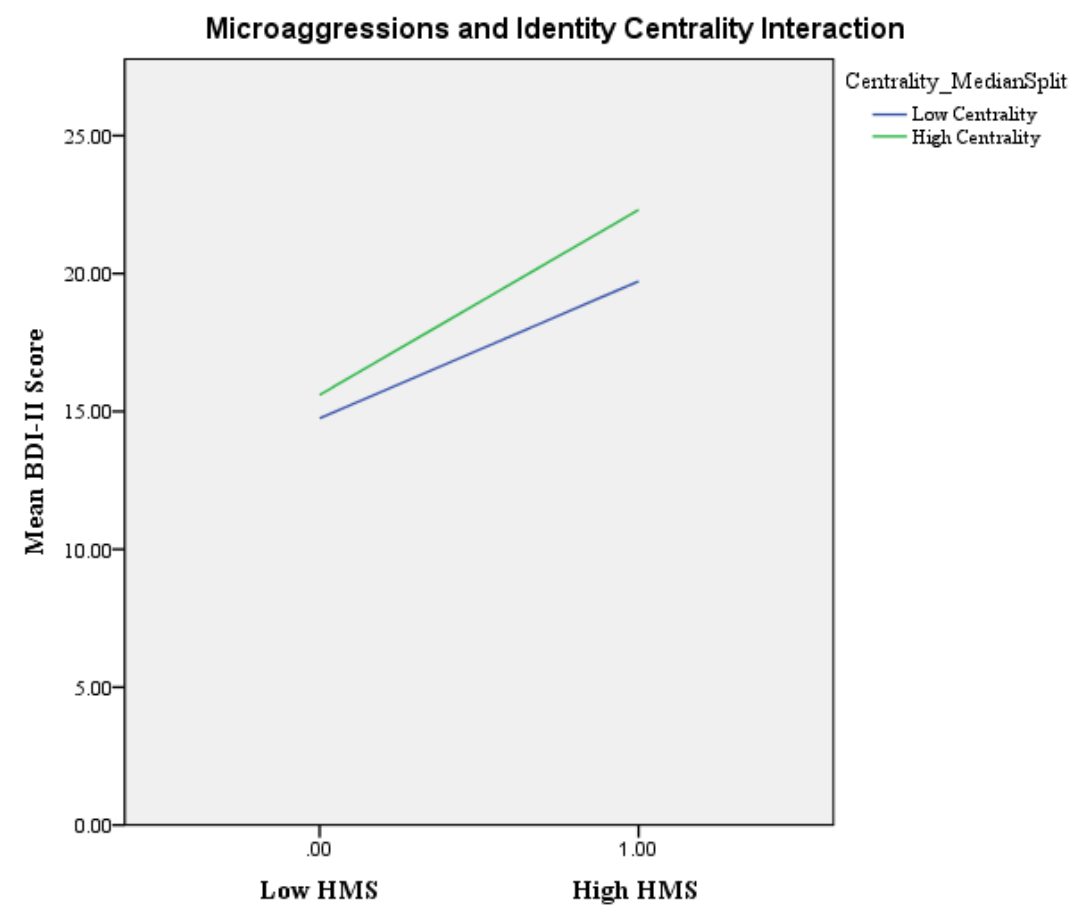

Note: $\mathrm{HMS}=$ Homonegative Microaggressions Scale; BDI-II = Beck Depression Inventory-II

Identity Affirmation was tested in the same manner as the two previous regression analyses. The overall model accounted for significant variance in depressive symptoms, 
$F(3,132)=3.368, p=.021$, with an $R^{2}=.072$. However, of the independent variables, only the HMS was significant $(\beta=0.230, p=.007)$, while Identity Affirmation $(\beta=$ $0.083, p=.330)$ and the interaction term were not significant $(\beta=0.132, p=.123)$. Despite not reaching significance, when examined graphically, the interaction variable demonstrated a pattern that was opposite of the hypothesis (see Figure 2). Higher Identity Affirmation appeared to exacerbate the impact of microaggressions, particularly in individuals reporting more experiences of microaggressions.

Figure 2.

Interaction between Microaggressions and Identity Affirmation with Respect to Depressive Symptom

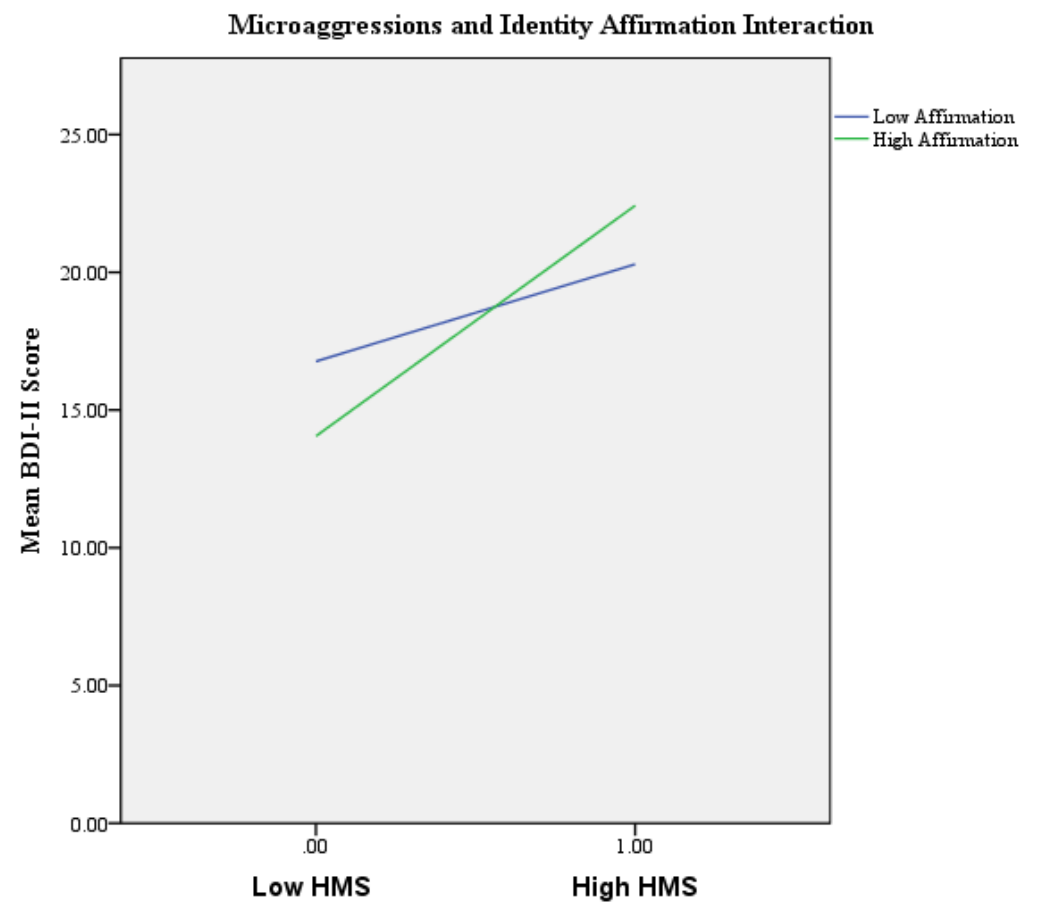

Note: $\mathrm{HMS}=$ Homonegative Microaggressions Scale; BDI-II = Beck Depression Inventory-II

Parallel analyses were conducted with the BAI as the dependent variable. None of these analyses showed a significant interaction between the positive identity variables and microaggressions, thus none supported the buffering hypothesis. 
For exploratory purposes, correlational analyses were conducted to examine whether negative identity subscales were associated with the BAI and BDI-II. Results indicated significant correlations between the BDI-II and four out of five LGBIS negative identity subscales, including Acceptance Concerns $(r=.319, p<.001)$, Concealment Motivation $(r=.179, p=.038)$, Identity Uncertainty $(r=.174, p=.043)$, and Difficult Process $(r=.243, p=.004)$. The BDI-II was also significantly correlated with the overall Negative Identity Subscale $(r=.222, p=.009)$. The BAI was only significantly correlated with Acceptance Concerns $(r=.263, p=.002)$ and Difficult Process $(r=.217$, $p=.012$ ). Given the significant correlation between the BDI-II and the overall Negative Identity Subscale, a linear regression was conducted to determine whether negative identity and microaggressions predicted unique variance in depressive symptoms. All variables met the assumptions of multicollinearity, outliers, and linear relationship between the mental health and independent variables. The HMS total score and LGBIS Negative Identity Subscale were entered into a linear regression with the BDI-II as the associated mental health variable. Results indicated this model accounted for significant variance in depressive symptoms, $F(2,132)=5.890, p=.004$, with an $R^{2}=.082$. This indicates that this two predictor model predicted $8.2 \%$ of the variance in depressive symptoms. Both the HMS $(\beta=0.184, p=.033)$ and the LGBIS Negative Identity

Subscale $(\beta=0.184, p=.033)$ predicted unique variance in the BDI-II.

\section{Aim 3: Protective Factors, Microaggressions, and Mental Health}

Hypothesis 3 predicted that positive identity would serve as a protective factor against microaggressions above and beyond the impact of outness and social support. To examine the contributions of each potential protective factor (social support, outness, and 
identity), it was proposed that two regression analyses would be conducted with anxiety as the dependent variable in one and depression in the other. Microaggressions were to be entered first into the equation. Then, each of the three protective variables were to be entered as main effects. Three interaction terms were to be created (social support $\mathrm{x}$ microaggressions; identity x microaggressions; outness x microaggressions) and entered into the model. However, as discussed in the previous section, the LGBIS positive identity subscales were not significantly correlated with the measures of mental health (BDI-II and BAI). Thus, the regression analysis was not conducted as planned.

Pearson bivariate correlational analyses among outness, social support, microaggressions, the BAI, and the BDI-II revealed only the HMS was significantly associated with the BAI, $r=.204, p=.018$. The Outness Inventory and MOS were not significantly correlated with the BAI. The BDI-II was significantly correlated with the MOS total score, $r=-.239, p=.005$, the Outness Inventory total score, $r=-.216, p=$ .012 , and the HMS, $r=.222, p=.010$. Thus, two separate regressions were conducted to examine the impact of social support and outness separately, and to test the buffering effect of these variables. In order to create interaction terms, respective mean scores on the HMS, Outness Inventory, and the MOS were subtracted from the total scores to center the variables at the mean. These variables were then multiplied (HMS*OI; HMS*MOS) to create interaction variables.

The MOS was examined in the first regression analysis. The overall model including the HMS, MOS, and the interaction variable was statistically significant, $F(3$, 131) $=4.55, p=.005$, with an $R^{2}=.094$. Examination of the standardized beta scores for each subscale revealed both the HMS $(\beta=.184, p=.032)$ and the $\operatorname{MOS}(\beta=-.216, p=$ 
.012) significantly accounted for variance in depressive symptoms. The interaction itself was not statistically significant $(\beta=-0.043, p=.609)$.

The second regression tested the buffering impact of the Outness Inventory. While the overall model including the HMS, Outness Inventory, and the interaction variable was significant, $F(3,131)=4.83, p=.003$, only the HMS demonstrated a significant main effect $(\beta=.229, p=.011)$. The Outness Inventory $(\beta=-.165, p=.056)$ and the interaction variable $(\beta=.153, p=.079)$ were not statistically significant.

A third regression was conducted to examine both potential protective factors in one model. This model included the HMS, Outness Inventory, MOS, and both interaction terms as independent variables, and with the BDI-II as the dependent variable. The overall model was significant, $F(5,129)=3.91, p=.002$. Only the $\operatorname{HMS}(\beta=.211, p=$ $.019)$ and the HMS*OI interaction $(\beta=.187, p=.048)$ accounted for significant variance in depressive symptoms. The OI main effect $(\beta=-.115, p=.208), \operatorname{MOS}(\beta=-.165, p=$ $.070)$, and HMS*MOS interaction $(\beta=-.121, p=.186)$ were not significant. In order to examine the interaction between the Outness Inventory and HMS, and their impact on depression scores, both independent variables were dichotomized at the median to create low/high groups. This interaction is shown in Figure 3, and shows that individuals who were higher on the OI generally were less depressed than those lower on the OI, but that this effect was stronger when participants reported more microaggressions. 
Figure 3.

Interaction between Microaggressions and Outness with Respect to Depressive Symptoms

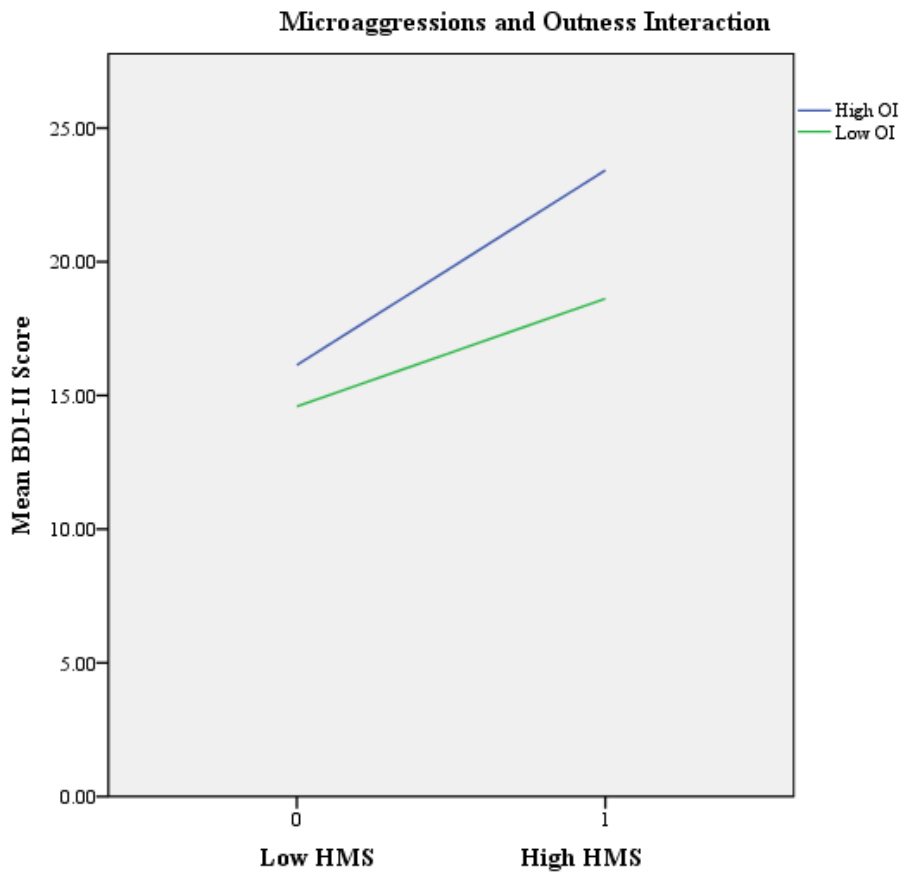

Note $:$ HMS = Homonegative Microaggressions Scale; OI = Outness Inventory

\section{Exploratory Analyses}

To further explore the relationship between Outness and identity, high and low outness groups (as defined with the OI, as per the analyses above, were compared across all LGBIS subscales. Results indicated significant differences on all LGBIS subscales except for Identity Superiority and Identity Affirmation, with the low outness group scoring significantly higher on all negative identity subscales. These results are shown in Table 4. 
Table 5

T-tests Comparing LGBIS Subscale Scores by Outness Group

\begin{tabular}{lllllll}
\hline \multirow{2}{*}{ LGBIS Subscale } & \multicolumn{3}{l}{ Low Outness } & \multicolumn{3}{l}{ High Outness } \\
\cline { 2 - 5 } & $\mathrm{M}$ & $\mathrm{SD}$ & $\mathrm{M}$ & $\mathrm{SD}$ & t-test \\
\hline Negative Identity Subscale & 3.42 & .76 & 2.74 & .76 & $5.17^{* *}$ \\
Acceptance Concerns & 4.02 & 1.11 & 3.23 & 1.21 & $3.80^{* *}$ \\
Concealment Motivation & 4.26 & 1.21 & 3.36 & 1.20 & $4.34^{* *}$ \\
Identity Uncertainty & 3.13 & 1.08 & 2.48 & 1.09 & $3.48^{* *}$ \\
Internalized Homonegativity & 2.67 & 1.16 & 2.09 & 1.22 & $2.80^{*}$ \\
Difficult Process & 3.80 & 1.00 & 2.94 & 1.14 & $4.68^{* *}$ \\
Identity Superiority & 1.99 & 1.09 & 2.14 & 1.11 & -.802 \\
Identity Affirmation & 4.35 & .98 & 4.67 & 1.29 & -1.62 \\
Identity Centrality & 3.35 & .93 & 3.85 & .99 & $-3.03^{*}$
\end{tabular}

Note: *Correlation is significant at the 0.05 level (2-tailed).

**Correlation is significant at the 0.01 level (2-tailed)

$\mathrm{M}=$ Mean, $\mathrm{SD}=$ Standard Deviation

A linear regression was also conducted to examine whether outness and social support predicted unique variance in the overall LGBIS negative identity subscale. The overall model was significant, $F(2,132)=20.73, p<.001$, with an $R^{2}=.239$. Both the Outness Inventory $(\beta=-.382, p<.001)$ and $\operatorname{MOS}(\beta=-.191, p=.022)$ demonstrated significant main effects.

\section{Post Hoc Analyses}

Given the high percentage of bisexual individuals in the current samples, all analyses were conducted again examining only the bisexual participants. The pattern of correlation coefficients was virtually identical to those found when the entire sample was assessed. No regression analyses in Aim 2 and 3 yielded significance with this smaller sample size. Exploratory analyses yielded similar patterns to those found with the entire LGB sample. 


\section{CHAPTER IV \\ DISCUSSION}

Previous research has established the negative impact of distal stressors, including discrimination and microaggressions, on sexual minority individuals (e. g., Platt and Lenzen, 2013). Homonegative microaggressions have been associated with a host of negative outcomes, including anxiety (Nadal et al, 2011b), depression (Silverschanz, Cortina, Konik, \& Magley, 2008), and negative feelings about one's sexual minority identity (Wright \& Wegner, 2012). Given the prevalence and unavoidable nature of these experiences, it is important to identify sources of coping and resilience to help buffer their negative impact. Because many LGB individuals lose some social support or face discrimination upon coming out (Rosario, Schrimshaw, \& Hunter, 2009), the purpose of the current study was to examine positive identity, an internal factor, as a source of coping in the face of microaggressions. Because there is a lack of research on LGB identity dimensions, this study also sought to examine the relationships between positive and negative aspects of identity, and to examine the unique impact of identity when compared to the related constructs of outness and social support, on measures of mental health. Increased understanding of these potential sources of coping may help psychotherapists develop interventions designed to bolster these resources in LGB clients. 


\section{Sample Overview}

The experience of LGB individuals can vary greatly as a function of geographical location, gender identity, sexual orientation, and a number of other characteristics. Thus, prior to examining these relationships, it was important to gain understanding of the sample under study. The current sample over-represents bisexual individuals, when compared to previous studies and national averages (Pew Research Center, 2013), who comprise roughly $78 \%$ of the current sample, with the rest evenly split between gay and lesbian participants. This is particularly noteworthy given that two key measures in the study, the HMS and the LGBIS, were validated in samples that included significantly fewer bisexual individuals than gay/lesbian participants, and because the current study found significant differences between bisexual participants and their gay/lesbian counterparts. Those group differences are consistent with previous studies using the LGBIS, or its earlier version, the LGIS (Mohr \& Fassinger, 2000), that have found higher levels of identity confusion or uncertainty and overall negative identity amongst their bisexual participants when compared to gay/lesbian participants (Balsam \& Mohr, 2007; de Oliveira et al., 2012; Sarno \& Wright, 2013). The current sample also scored significantly lower on positive identity variables and higher on negative identity subscales than Mohr and Kendra's (2011) sample, indicating the sample under study may have had more difficulty with identity formation than the comparison sample. This pattern was also observed when the current sample was compared to the findings of Cramer and colleagues (2018). Interestingly, despite the patterns of negative and positive identity, the current sample appeared to score lower on the BDI-II, in the mild range, than other majority-college student samples (Cohen, Blasey, Taylor, Weiss, \& Newman, 2016; 
Heck, Lindquist, Machek, \& Cochran, 2014), but with similar variability. The current sample's mean BAI score fell in the moderate range, while experiences of microaggressions were slightly higher than the findings of Wright \& Wenger (2012), albeit not significantly higher.

\section{Positive and Negative Identity}

Since negative identity factors, such as internalized homophobia, are associated with negative mental health outcomes (Igartua, Gill, \& Montoro, 2003) and can compound the impact of discriminatory experiences (Hatzenbuehler, 2009; Newcomb \& Mustanski, 2010), the first hypothesis examined in this study stated that all three positive identity facets would be negatively correlated with the five negative identity dimensions of the LGBIS scale. However, findings were mixed, and overall suggested that participants may experience high (or low) levels of positive and negative identity simultaneously. Of the positive identity factors, affirmation, or one's positive feelings regarding their identity, demonstrated the highest number of significant correlations with negative identity facets, indicating its importance to one's overall identity. This is particularly important given its strong negative association with internalized homonegativity, a construct associated with numerous negative mental health outcomes. Interestingly, centrality, the positive dimension associated with how important identity is to one's overall sense of self, was associated in opposite directions with two negative identity subscales. Centrality was positively associated with concerns that one will not be accepted because of their LGB identity and negatively associated with internalized homonegativity. This suggests that individuals with high centrality scores may generally feel positively about their identities, given the negative association with 
internalized homonegativity, view this identity as centrally important, but perhaps consequently fear rejection. That is, experiencing rejection or discrimination directed toward an identity that one views as central can increase the perception and negative impact of those distal stressors (Hatzenbuehler, Nolen-Hoeksema, \& Erickson, 2008; Feinstein, Goldfried, \& Davila, 2012). This is consistent with previous research associating identity salience with heightened fear and perceptions of rejection (Sellers \& Shelton, 2003).

Furthermore, while all negative identity subscales were significantly correlated with each other, the positive identity factors were mixed, with identity superiority demonstrating no association with affirmation. This is consistent with Wegner's hypothesis (2014) that viewing one's identity as superior to others who do not share this identity may be a defense in the face of various forms of discrimination, and with the findings of Cramer et al. (2018) that superiority was not associated with either positive identity subscale of the LGBIS. The findings of the current study, as well as Wenger (2014) and Cramer and colleagues (2018), raise questions about the inclusion of identity superiority as a positive identity factor. In addition, past research findings on this construct have been largely negative: it has been negatively associated with well-being (Balsam \& Mohr, 2007) and relationship quality (Mohr \& Fassinger, 2006), and positively associated with internalized homophobia (Cramer et al., 2018), centrality and stigma sensitivity in gay and bisexual men (de Oliveira, Lopes, Costa, \& Nogueira, 2012), and depression and anxiety in a sample of Kenyan men (Harper et al., 2015). Cramer and colleagues (2018) have also questioned the categorization of identity superiority. They reported patterns of association of identity superiority with coping and 
measures of well-being that were more in line with the negative identity subscales than the other positive identity subscales. They used this information to counter the notion that identity superiority is a positive element of LGB identity. It may be that superiority serves both a positive and negative role in one's LGB identity, as it may indicate embracing one's identity (McCarn \& Fassinger, 1996) while also representing one's recognition of societal heterosexism that can lead to defensiveness (Mohr \& Fassinger, 2000). Thus, superiority may function differently depending on context.

\section{Identity Dimensions and Bisexuality}

It is important to consider the overrepresentation of bisexual individuals previously mentioned, who comprise over three quarters of the current sample. Group differences were seen across a number of identity scales, with the most common trend indicating bisexual individuals score higher on negative identity subscales and lower on positive identity subscales than lesbian participants. Bisexual identity formation has been characterized by higher uncertainty and increased difficulty forming identity, and is a complicated process given discrimination from within the LGBTQ+ community and from the heterosexual majority community (Mohr \& Kendra, 2011; Dyar, Feinstein, \& London, 2014). Thus, the overrepresentation of bisexual individuals may skew the current data toward the experience of bisexual individuals when compared to previous studies that have examined similar constructs (Mohr \& Kendra, 2011) and account for differences found across the identity subscales.

\section{Positive Identity, Microaggressions, and Mental Health}

The primary hypothesis under study was that positive identity dimensions, such as affirmation, would serve as buffers against symptoms of depression and anxiety when 
one is faced with microaggressions. It was found that affirmation and superiority were not significantly associated with depression or anxiety, and, contrary to expectation, centrality was associated with depression in the positive direction. The buffering hypotheses regarding the positive identity subscales were not supported. Instead, higher centrality and affirmation actually were associated with increased depressive symptoms when paired with higher levels of microaggressions. Given that centrality is associated with increased acceptance concerns, it may be that experiences of microaggressions bring this fear to the forefront and subsequently increase the impact of microaggressions. These findings are consistent with the body of literature that has examined identity salience or centrality in ethnic and sexual minority individuals and found that increased importance of these stigmatized identities may lead to higher reporting of distal stressors and increased impact (Meyer, 2003; Sellers \& Shelton, 2003), lending further credence to the findings and hypotheses of Cramer et al. (2018). Also, as previously mentioned, viewing one's identity as superior may function as a defense for some individuals but not for others, which may explain the lack of a significant association between this subscale and the mental health variables. Affirmation is an understudied construct in the LGB literature, with only one study examining its relationship to discrimination experienced by Asian American individuals (Park et al., 2013). Affirmation has been negatively associated with depression, fear, sadness, guilt, and hostility (Mohr \& Kendra, 2011). Past research has suggested identity affirmation may serve as a buffer once it reaches a specific point (Kertzner, Meyer, Frost, \& Stirratt, 2009; Mohr \& Kendra, 2011; Dyar, Feinstein, \& London, 2014), however these findings were not supported by the current study. While not significant, our findings instead showed a pattern that microaggressions 
have a stronger impact on those who feel more positively about their identity. The current study's findings on affirmation may be impacted by the majority bisexual sample scoring significantly lower on this subscale than lesbian participants, and lower than gay participants, albeit not significantly. Because this sample also scored higher on negative identity subscales than the LGBIS validation sample, exploratory analyses examined whether negative identity and microaggressions predicted unique variance in depressive symptoms. Both of these variables significantly accounted for variance in depression scores. This further illustrates the negative impact of microaggressions and negative identity constructs, such as internalized homonegativity and concealment, consistent with past research (Igartua \& Montoro, 2003; Hoy-Ellis, 2016).

\section{External Coping Resources}

While positive identity was not found to be a source of coping, it was still important to address the potential buffering impact of outness and social support in order to identify methods for coping, given the aforementioned association between microaggressions and depressive symptoms. Past results have been mixed, with social support generally serving as a protective factor for LGB individuals (Meyer, Schwartz, \& Frost, 2008). However, gay men may seek out support only from other LGB individuals

for major concerns or emergencies (Frost, Meyer, \& Schwartz, 2017). Other research has also suggested social support is not enough to be protective unless it is LGB-specific social support (Szymanski \& Carr, 2008), and illustrates the importance of LGB community connectedness (e.g., Frable, Platt, \& Hoey, 1998; Frost \& Meyer, 2012). Research has also indicated LGB men and women primarily rely on other LGB members for social support (Frost, Meyer, \& Schwartz, 2016). This highlights the importance of 
outness, because concealment limits access to social support related to LGB identity. Three separate regression analyses shed light on the relationships among social support, outness, microaggressions, and depressive symptoms, and yielded mixed findings regarding social support and outness as protective factors. In the first regression analysis using only social support as a source of coping, the interaction of social support and microaggressions was not significant, indicating social support did not serve a buffering effect for depressive symptoms when one is faced with microaggressions. This result conflicts with past research demonstrating that social support is a source of coping. However, these findings may be consistent with the findings of Mustanski and colleagues (2011), who found that family support is correlated with reduced distress, but may only serve a minimal buffering role in the face of discrimination. They included two forms of social support, peer and family, and still found a significant association between victimization and negative outcomes in their multivariate model. The present study further supports previous findings that LGB-specific social support may be a more important source of coping than general social support, particularly in certain scenarios. In the second regression, outness was entered as the source of coping and as the potential buffer, with results indicating outness did not serve as a buffer. However, when social support, outness, and their respective interactions with microaggressions were entered into one equation, the outness and microaggressions interaction was indeed significant, indicating a buffering effect. When this relationship was examined graphically with dichotomized microaggressions and outness scores, it was clear that individuals who report more outness had lower depression scores overall, but that this relationship was more pronounced in individuals who experienced a high number of 
microaggressions. The importance of outness in the current study lends support to research that points to LGB-specific social support, rather than general social support, as the important factor in terms of coping (Frost, Meyer, \& Schwartz, 2016), particularly for individuals who report increased experiences of microaggressions. While individuals who are not out may have access to social support generally, concealing one's identity deprives them of the opportunity to create community-specific relationships, which are very important given the collective nature of LGB identities.

The importance of outness and social support were illustrated through exploratory analyses. The sample was dichotomized into high and low outness groups, with results indicating those higher in outness scored significantly lower on all negative identity subscales and higher on centrality. Furthermore, outness and social support both accounted for unique variance in the higher order negative identity factor, with negative beta coefficients suggesting increases in social support and outness are associated with decreases in negative identity. However, the cross-sectional nature of the study limits the ability to draw conclusions regarding this outcome. It is worth noting that both social support and outness contributed unique variance, indicating they are unique constructs that are important to bolster in LGB individuals. While some individuals may benefit from the protective nature of concealing their identities, social support can still be associated with improved identity. For others who are able to come out, their outness can help them access LGB-specific social support and general social support, with both serving an important function in their overall identity. 


\section{Limitations}

One major limitation of this study is the cross-sectional nature of the data. This does not allow for causal conclusions, or for examination of potentially cyclical relationships between these study variables. Identity development is an ongoing process that may best be studied with longitudinal research designs. Future studies may examine variables related to microaggressions, coping, and identity, to determine whether there is a path through which the various identity factors, outness, and social support function as sources of coping or resilience. The study is also limited by the difficulty in measuring microaggressions. The microaggressions questionnaire used in this study includes items that appear to measure outright discrimination (i.e., "how often have people assumed you were a pedophile?"), rather than experiences of microaggressions. Furthermore, as the impact of microaggressions and discrimination largely depends on the victim's perception, self-report of these experiences may be skewed based on individuals factors, such as rejection sensitivity. Future studies may continue to examine the measurement of microaggressions and seek to examine this construct through other methods. The study is also impacted by the use of only one item to assess sexual orientation, as the experiences of individuals within the same sexual identity category (e.g., bisexual) may vary greatly depending on one's context. Future studies may include additional methods for assessing sexual identity, such as measuring sexual orientation on a continuum and including measures, such as the Sell Assessment of Sexual Orientation (Sell, 1996), in order to further capture participants' experiences with their sexual identity. Also, as previously mentioned, the data in this sample may be skewed toward the experience of bisexual individuals given their overrepresentation compared to gay and lesbian participants. The 
group differences found on various identity subscales highlight the differences among these groups, particularly between bisexual and lesbian participants. This may limit the generalizability of these findings to individuals who have greater homonegativity and less outness than may be typical in the gay and lesbian communities. Sub-group analyses were inconclusive with respect to whether the findings are more representative of bisexual participants than of the other groups. Generalizability may be further limited by regional differences of a Midwest sample. Whereas the University of Louisville campus is known for its LGBTQ+-friendly culture, some participants may have moved to the university from conservative neighboring towns that may not be supportive of LGBTQ+ individuals. Findings might be different if similar analyses were conducted with participants from different regions of the United States. Furthermore, the majority college-age sample may limit generalizability. Sexual identity formation is a continuous process, but is especially prominent during one's college years. Similar analyses in a sample with different demographic makeup may yield different results. For example, older LGBTQ+ individuals may report more experiences of microaggressions given more negative attitudes toward sexual minority individuals in previous decades, however, they may be more settled in their identities and have established social support networks. Additionally, examination of intersectionality is limited in this study, with the sample consisting mainly of White, bisexual, women. Future studies may seek to recruit more ethnically diverse individuals across the gender spectrum.

The current study is also limited by measurement concerns. While the LGBIS assesses three positive dimensions of identity, two have been demonstrated in the literature to either not function as protective, or even have a detrimental impact on well- 
being. Thus, this leaves only affirmation as a reasonably well-established positive identity subscale that may serve a buffering role, although affirmation did not function as a buffer against depression in the current study, and appeared to actually increase the negative impact of microaggressions. This study is also limited by the single choice method of classifying one's sexual orientation, as sexual identity includes and is impacted by sexual and emotional attraction, and experiences. The study also did not assess age upon coming out or experience with same and opposite sex relationships, which may also contribute to differences in experience.

\section{Implications and Future Directions}

While support was not found for positive identity as protective, the current study supports previous research that has established the relationships between negative identity factors, such as concealment or internalized homonegativity, and mental health symptoms such as depression. It is important that the field continue to develop interventions for reducing these aspects of sexual minority identities and continue utilizing LGBTQ+-affirming therapy techniques in order to support clients, particularly those who have faced repeated experiences of microaggressions. The current study did also lend support to the importance of outness. One perspective on the beneficial impact of outness is that it increases public awareness of LGBTQ+ individuals, creating a foundation for other sexual minority individuals to come out or advocate for the community (Shepard, 2009). It has also been found that outness predicts unique variance in social support (Balsam \& Mohr, 2007), thus it may be important to help LGBTQ+ clients find spaces in which they feel safe coming out in order to access social support, particularly from individuals who can support their LGBTQ+ identities. This may be 
particularly important in the context of "strategic outness," in which LGBTQ+ individuals continuously manage the concealment or outing of their identities depending on their context (Orne, 2011). Similar to the construct of sexual identity, outness has shifted from being seen from a stage approach (Cass, 1979) to a continuous process (Orne, 2011). Future studies may continue to examine the differential impact of outness and general social support. Additionally, as coming out is a continuous process, future studies may examine the impact of coming out in certain contexts, such as within one's religious community, which has been shown to be associated with lower levels of depression (Escher et al., 2018), but concealing one's identity in other contexts, such as the workplace.

The current study also added to the body of literature that addresses the ambiguous roles of identity superiority and centrality, two of the three hypothesized positive identity dimensions. As previously mentioned, superiority may serve as a defensive reaction or method for coping with stigma related to one's identity (Troiden, 1993). Others have also hypothesized that viewing one's LGB identity as superior to heterosexual identities is a disguised representation of one's internalized homophobia (Margolies, Becker, \& Jackson-Brewer, 1987). Centrality has also yielded mixed findings in the sexual identity and ethnic identity literature, which may explain the lack of significant associations between this identity subscale and the mental health variables. However, one major issue with the available literature on sexual identity is the lack of consistency in the measurement of identity. Research that has shown positive identity variables to be associated with negative outcomes has often studied these variables in isolation. One main aim of the current study was to examine the measurement of identity 
from a multidimensional approach and to examine the relationships between positive and negative identity dimensions. According to minority stress theory (Meyer, 2003), one is less impacted by distal stressors when they have achieved "positive identity valence." While the theory posits positive identity dimensions, such as centrality, are part of this positive identity valence, reducing negative dimensions, such as internalized homonegativity, are also considered important factors in achieving this valence. Thus, the findings of the current study, and past research showing positive identity factors can sometimes be associated with negative measures of mental health, may support the notion that it is not increasing positive identity dimensions alone that is protective, one must also decrease negative identity factors in order for LGB identity to be protective. This is particularly important when considering the high levels of internalized homophobia, concealment, and other negative identity factors in the current sample. While one may be high in centrality, if they are also high in internalized homophobia, experiences of microaggressions may readily trigger one's negative beliefs about their own identity and they may be unable to access their positive beliefs, which parallels hypotheses regarding ethnic identity (Bynum et al., 2008). The current study examined one positive identity factor at a time in each analysis related to the buffering hypothesis. It is important that future research examines these variables in conjunction to determine how identity as a whole impacts the relationship between microaggressions and mental health. This may lead to the validation of an identity profile that is most predictive of well-being. Balsam \& Mohr (2007) used regression analyses to determine that participants who are low in stigma sensitivity, internalized homonegativity, and identity superiority had the highest levels of well-being. Future research may seek to continue this line of study with respect 
to coping with microaggressions or other forms of discrimination. Based on the current study and past research, it appears these identity dimensions do not function in isolation, and identifying a healthy identity profile can help tailor treatments and identify clients who may be most susceptible to the negative impact of distal stressors.

The findings of the current study may also highlight the experiences of the majority bisexual sample. Bisexual individuals tend to score higher on measures related to difficulty with identity formation (Balsam \& Mohr, 2007; Cox, Vanden Berghe, \& Dewaele, 2010), as they form a sexual identity that is stigmatized by the larger majority community (Herek, 2002), and they experience rejection and erasure from within their LGBTQ+ community (Balsam \& Mohr, 2007). Bisexual individuals may struggle with outness, given the difficulty coming out to an in-group that may not believe bisexual identities are legitimate. Relationship status may also be particularly impactful, because being in an opposite sex relationship can lead to difficulty sharing one's bisexual identity, decreased visibility, and greater exclusion (Ochs, 1996; Morris \& Rothblum, 1999). Given the hypotheses regarding "positive identity valence," it would seem there may be a threshold at which one's LGB identity becomes central and affirmed enough, through outness, social support, and other methods, to serve a buffering role. With the difficulties faced by bisexual individuals in their identity formation processes, it may be that the current sample did not achieve affirmation levels that are in line with this "positive identity valence," and thus these identities are not serving as protective factors. It is important that future research focus on the unique experience of bisexual individuals, particularly with regard to identity, rather than grouping all sexual minority individuals together. Additionally, past research has identified themes of microaggressions 
experienced more frequently by female LGB individuals, including exoticization or being told their sexual orientation is just a phase (e.g., Platt \& Lenzen, 2013), however, these studies are limited and include data from focus groups rather than quantitative data (Nadal et al., 2011a). Given the findings of this study and the unique experiences of bisexual, lesbian, and gay individuals previously cited, it may be important to assess whether different forms of microaggressions impact sexual minority individuals differently. This is particularly important given the unique experiences of each sexual minority individual, and the double discrimination experienced by bisexual individuals (Friedman et al., 2014).

Overall, it is important that future research in this field continue to increase understanding of methods through which LGBTQ+ individuals can cope or increase their resilience. These methods may need to be tailored to account for an individual's subgroup within the community, intersectionality, and one's environmental context. While attitudes toward the sexual minority community are improving, experiences of various forms of microaggressions, outright discrimination, and loss of social support remain prevalent and will likely continue, thus it is critical that we continue to develop and increase our understanding of sources of coping that function on the personal level for this community. 


\section{REFERENCES}

Adams, H. L., \& Phillips, L. (2009). Ethnic related variations from the Cass model of homosexual identity formation: The experiences of two-spirit, lesbian and gay Native Americans. Journal of Homosexuality, 56(7), 959-976.

American Psychiatric Association. (1968). Diagnostic and statistical manual of mental disorders (2nd ed.). Washington, DC: American Psychiatric Association.

Amnesty International. (2011, May 29). Amnesty International annual report 2001. Retrieved from https://www.amnesty.org/en/documents/pol10/0001/2001/en/.

Ashmore, R. D., Deaux, K., \& McLaughlin-Volpe, T. (2004). An organizing framework for collective identity: Articulation and significance of multidimensionality. Psychological Bulletin, 130, 80-114.

Balsam, K. F., \& Mohr, J. J. (2007). Adaptation to sexual orientation stigma: A comparison of bisexual and lesbian/gay adults. Journal of Counseling Psychology, 54, 306-319.

Balsam, K. F., Molina, Y., Beadnell, B., Simoni, J., \& Walters, K. (2011). Measuring multiple minority stress: The LGBT people of color microaggressions scale. Cultural Diversity and Ethnic Minority Psychology, 17, 163-174. 
Bombay, A., Matheson, K., \& Anisman, H. (2010). Decomposing identity: Differential relationships between several aspects of ethnic identity and the negative effects of perceived discrimination among First Nations adults in Canada. Cultural Diversity and Ethnic Minority Psychology, 16, 507-516.

Bosker, M. J. (2002). Assessing level of outness among gay, lesbian, and bisexual individuals and its relation to depression, anxiety, and self-esteem (Doctoral dissertation). Southern Illinois University.

Branscombe, N. R., Schmitt, M. T., \& Harvey, R. D. (1999). Perceiving pervasive discrimination among African-Americans: implications for group identification and well-being. Journal of Personality and Social Psychology, 77, 135-149.

Bregman, H. R., Malik, N. M., Page, M. J. L., Makynen, E., \& Lindahl, K. M. (2013). Identity profiles in lesbian, gay, and bisexual youth: The role of family influences. Journal of Youth and Adolescence, 42, 417-430.

Brondolo, E., ver Halen, N. B., Pencille, M., Beatty, D., \& Contrada, R. J. (2009). Coping with racism: A selective review of the literature and a theoretical and methodological critique. Journal of Behavioral Medicine, 32, 64-88.

Burrow, A. L., \& Ong, A. D. (2010). Racial identity as a moderator of daily exposure and reactivity to racial discrimination. Self and Identity, 9(4), 383-402.

Bynum, M. S., Best, C., Barnes, S. L., \& Burton, E. T. (2008). Private regard, identity protection and perceived racism among African American males. Journal of African American Studies, 12, 142-155. 
Caldwell, C. H., Zimmerman, M. A., Bernat, D. H., Sellers, R. M., \& Notaro, P. C. (2002). Racial identity, maternal support, and psychological distress among African American adolescents. Child Development, 73(4), 1322-1336.

Carter, R. T. (2007). Racism and psychological and emotional injury: Recognizing and assessing race-based traumatic stress. The Counseling Psychologist, 35(1), 13105.

Cass, V.C. (1979). Homosexual identity formation: A theoretical model. Journal of Homosexuality, 4, 219-253.

Cass, V.C. (1984a). Homosexual identity formation: Testing a theoretical model. The Journal of Sex Research, 20, 143-167.

Cass, V. C. (1984b). Homosexual identity: A concept in need of definition. Journal of Homosexuality, 9(2-3), 105-126.

Chae, D. H. \& Walters, K. L. (2007). Racial discrimination and racial identity attitudes in relation to self-rated health and physical pain and impairment among two-spirit American Indians/Alaska natives. American Journal of Public Health, 99, 51445151.

Chaudoir, S. R., Dugan, A. G., \& Barr, C. (2013). Measuring factors affecting implementation of health innovations: A systematic review of structural, organizational, provider, patient, and innovation level measures. Implementation Science, 8, 1-20.

Cohen, J. M., Blasey, C., Taylor, C. B., Weiss, B. J., \& Newman, M. G. (2016). Anxiety and related disorders and concealment in sexual minority young adults. Behavior Therapy, 47, 91-101. 
Cohen, S., Kamarck, T., \& Mermelstein, R. (1983). A global measure of perceived stress. Journal of Health and Social Behavior, 24, 385-396.

Cox, N., Vanden Berghe, W., Dewaele, A., \& Vincke, J. (2010). Acculturation strategies and mental health in gay, lesbian, and bisexual youth. Journal of Youth and Adolescence, 39, 1199- 1210.

Cramer, R. J., Golom, F. D., Gemberling, T. M., Trost, K., Lewis, R., \& Wright, S. (2018). Examining the lesbian, gay, and bisexual identity scale among members of an alternative sexuality special interest group. Archives of Sexual Behavior, 47, $1251-1264$.

Cross, W. E. (2005). Ethnicity, race, and identity. In T.S. Weisner (Ed.), Discovering successful pathways in children's development: Mixed methods in the study of childhood and family life (pp. 171-182). Chicago: University of Chicago Press.

D’Augelli, A. R. (1994). Identity development and sexual orientation: Toward a model of lesbian, gay, and bisexual development. In E. J. Trickett, R. J. Watts, and D. Birman (eds.), Human Diversity: Perspectives on People in Context. San Francisco: Jossey-Bass.

D’Augelli, A. R. (2002). Mental health problems among lesbian, gay, and bisexual youths ages 14 to 21. Clinical Child Psychology and Psychiatry, 7, 439-462.

de Oliveira, J. M., Lopes, D., Costa, C. G., \& Nogueira, C. (2012). Lesbian, Gay, and Bisexual Identity Scale (LGBIS): Construct validation, sensitivity analyses and other psychometric properties. The Spanish Journal of Psychology, 15(1), 334347. 
Denton, F. N. (2012). Minority stress and physical health in lesbians, gays, and bisexuals: The mediating role of coping self-efficacy (Doctoral dissertation). Retrieved from http:// uknowledge.uky.edu/edp_etds/2/

Diener, E., Emmons, A., Larsen, R.J., \& Griffin, S. (1985). The Satisfaction with Life Scale: A measure of life satisfaction. Journal of Personality Assessment, 49, 7175.

DiPlacido, J. (1998) Minority stress among lesbians, gay men and bisexuals: a consequence of heterosexism, homophobia and stigmatization. In Herek, G. (ed.), Stigma and Sexual Orientation, pp. 138-159. SAGE: Thousand Oaks, CA.

Denton, F. N., Rostosky, S. S., \& Danner, F. (2014). Stigma-related stressors, coping self-efficacy, and physical health in lesbian, gay, and bisexual individuals. Journal of Counseling Psychology, 61(3), 383-391.

Dyar, C., Feinstein, B. A., \& London, B. (2014). Dimensions of sexual identity and minority stress among bisexual women: The role of partner gender. Psychology of Sexual Orientation and Gender Diversity, 1(4), 441-451.

Eliason, M. J. (1996). Identity formation for lesbian, bisexual, and gay persons: Beyond a minoritizing view. Journal of Homosexuality, 30, 31-58.

Escher, C., Gomez, R., Paulraj, S., Ma, F., Spies-Upton, S., Cummings, C., Brown, L. M., Tormala, T. T., \& Goldblum, P. (2018). Relations of religion with depression and loneliness in older sexual and gender minority adults. Clinical Gerontologist.

Fassinger, R. E. (1991). The hidden minority: Issues and challenges in working with lesbian women and gay men. Counseling Psychologist, 19, 157-176. 
Feinstein, B. A., Goldfried, M. R., \& Davila, J. (2012). The relationship between experiences of discrimination and mental health among lesbians and gay men: An examination of internalized homonegativity and rejection sensitivity as potential mechanism. Journal of Counseling and Clinical Psychology, 80, 917-927.

Feldman, S. E. \& Wright, A. J. (2013) Dual impact: Outness and LGB identity formation on mental health. Journal of Gay \& Lesbian Social Services, 25, 443-464

Fingerhut, A. W., Peplau, L. A., \& Gable, S. L. (2010). Identity, minority stress and psychological well-being among gay men and lesbians. Psychology and Sexuality, $1,101-114$.

Frable, D. S., Platt, L., \& Hoey, S. (1998). Concealable stigmas and positive selfperceptions: Feeling better around similar others. Journal of Personality and Social Psychology, 74(4), 909-922.

Frederick-Goldsen, K. I. \& Muraco, A. (2010). Aging and sexual orientation: A 25-year review of the literature. Research on Aging, 32, 372-413.

Friedman, M. R., Dodge, B., Schick, V., Herbenick, D., Hubach, R. D., Bowling, J., Goncalves, G., Krier, S., \& Reece, M. (2014). From bias to bisexual health disparities: Attitudes toward bisexual men and women in the United States. $L G B T$ Health, 1(4), 309-318.

Frost, D. M., Lehavot, K., \& Meyer, I. H. (2015). Minority stress and physical health among sexual minority individuals. Journal of Behavioral Medicine, 38(1), 1-8.

Frost, D. M., \& Meyer, I. H. (2012). Measuring community connectedness among diverse sexual minority populations. Journal of Sex Research, 49(1), 36-49. 
Frost, D. M., Meyer, I. H., \& Schwartz, S. (2016). Social support networks among diverse sexual minority populations. The American Journal of Orthopsychiatry, 86(1), 91-102.

Fydrich, T., Dowdall, D., \& Chambless, D. L. (1992). Reliability and validity of the Beck Anxiety Inventory. Journal of Anxiety Disorders, 6(1), 55-61.

Gattis, M. N., Woodford, M. R., \& Han, Y. (2014). Discrimination and depressive symptoms among sexual minority youth: Is gay-affirming religious affiliation a protective factors? Archives of Sexual Behavior, 43, 1589-1599.

Gattis, M. N. \& Larson, A. (2017). Perceived microaggressions and mental health in a sample of black youths experiencing homelessness, Social Work Research, 41, 717.

Grossman, A. H., D’Augelli, A. R., \& O’Connel, T. S. (2002). Being lesbian, gay, bisexual and 60 or older in North America. Journal of Gay \& Lesbian Social Services, 13, 23-40.

Halpin, S. A. \& Allen, M. W. (2004). Changes in psychosocial well-being during stages of gay identity development. Journal of Homosexuality, 47, 109-126.

Harper, G. W., Wade, R. M., Onyango, D. P., Abuor, P. A., Bauermeister, J. A., Odero, W. W., \& Bailey, R. C. (2015). Resilience among gay/bisexual young men in Western Kenya: Psychosocial and sexual health outcomes. AIDS, 29, 261-269.

Hatzenbuehler, M. L. (2009). How does sexual minority stigma 'get under the skin'? A psychological mediation framework. Psychological Bulletin, 135(5), 707-730.

Hatzenbuehler, M. L., Nolen-Hoeksema, S., \& Erickson, S. J. (2008). Minority stress predictors of HIV risk behavior, substance use, and depressive symptoms: Results 
from a prospective study of bereaved gay men. Health Psychology, 27(4), 455462.

Hatzenbuehler, M. L., Nolen-Hoeksema, S., \& Erickson, S. J. (2009). Minority stress predictors of HIV risk behavior, substance use, and depressive symptoms: Results from a prospective study of bereaved gay men. Health Psychology, 27(4), 455462.

Heck, N. C., Lindquist, L. M., Machek, G. R., \& Cochran, B. N. (2014). School belonging, school victimization, and the mental health of LGBT young adults: Implications for school psychologists. School Psychology Forum, 8, 28-37.

Herek, G. M. (2002). Heterosexuals' attitudes toward bisexual men and women in the United States. Journal of Sex Research, 39(4), 264-274.

Herek, G. M., Gillis, J. R., \& Cogan, J. C. (1999). Psychological sequelae of hate-crime victimization among lesbian, gay, and bisexual adults. Journal of Consulting and Clinical Psychology, 67(6), 945.

Higa, D., Hoppe, M. J., Lindhorst, T., Mincer, S., Beadnell, B., Morrison, D. M., Wells, E. A., Todd, A., \& Mountz, S. (2014). Negative and positive factors associated with the well-being of lesbian, gay, bisexual, transgender, queer, and questioning (LGBTQ) youth. Youth \& Society, 46(5), 663-687.

Hoy-Ellis, C. P. (2016). Concealing concealment: The mediating role of internalized heterosexism in psychological distress among lesbian, gay, and bisexual older adults. Journal of Homosexuality, 63(4), 487-506. 
Hughes, D., Rodriguez, J., Smith, E. P., Johnson, D. J., Stevenson, H. C., \& Spicer, P. (2006). Parents' ethnic-racial socialization practices: A review of research and directions for future study. Developmental Psychology. 42, 747-770.

Igartua, K. J., Gill, K., \& Montoro, R. (2003). Internalized homophobia: A factor in depression, anxiety, and suicide in the gay and lesbian population. Canadian Journal of Community Mental Health, 22(2), 15-30.

Jordan, K. M., \& Deluty, R. H. (1998). Coming out for lesbian women: Its relation to anxiety, positive affectivity, self-esteem and social support. Journal of Homosexuality, 35, 41-63.

Kertzner, R. M. (1999). Self-appraisal of life experience and psychological adjustment in midlife gay men. Journal of Psychology and Human Sexuality, 11, 43-64.

Kertzner, R. M., Meyer, I. H., Frost, D. M., \& Stirratt, M. J. (2009). Social and psychological well-being in lesbians, gay men, and bisexuals: The effects of race, gender, age, and sexual identity. American Journal of Orthopsychiatry, 79, 500510.

Lane, J. D., \& Wegner, D. M. (1995). The cognitive consequences of secrecy. Journal of Personality and Social Psychology, 69(2), 237-253.

Leary, M. R., Tate, E. B., Adams, C. E., Batts-Allen, A., \& Hancock, J. (2007). Selfcompassion and reactions to unpleasant self-relevant events: the implications of treating oneself kindly. Journal of personality and social psychology, 92(5), 887.

Luhtanen, R. K. (2002). Identity, stigma management, and well-being: A comparison of lesbians/bisexual women and gay/bisexual men. Journal of Lesbian Studies, 7, 85-100. 
Margolies, L., Becker, M., \& Jackson-Brewer, K. (1987). Internalized homophobia: Identifying and treating the oppressor within. In Boston Lesbian Psychologies Collective (Eds.), Lesbian psychologies (pp. 2290-241). Urbana: University of Illinois Press.

Martos, A., Nezhad, S., \& Meyer, I. H. (2015). Variations in Sexual Identity Milestones among Lesbians, Gay Men and Bisexuals. Sexuality Research \& Social Policy: Journal of NSRC : SR \& SP, 12(1), 24-33.

Mayfield, W. (2001). The development of an internalized homonegativity inventory for gay men. Journal of Homosexuality, 41, 53-76.

Mays, V. M., \& Cochran, S. D. (2001). Mental health correlates of perceived discrimination among lesbian, gay, and bisexual adults in the United States. American Journal of Public Health, 91(11), 1869-1876.

McCarn, S. R., \& Fassinger, R. E. (1996). Revisioning sexual minority identity formation: A new model of lesbian identity and its implications. The Counseling Psychologist, 24(3), 508-534.

McKirnan, D., \& Peterson, P.L. (1989). Alcohol and drug use among homosexual men and women: epidemiology and population characteristics. Addictive Behaviors, 14, 545-0553.

Meyer, I. H. (1995). Minority stress and mental health in gay men. Journal of Health and Social Behavior, 38-56.

Meyer, I. H. (2003). Prejudice, social stress, and mental health in lesbian, gay, and bisexual populations: conceptual issues and research evidence. Psychological Bulletin, 129(5), 674. 
Meyer, I. H. (2007). Prejudice and discrimination as social stressors. In I. H. Meyer \& M. E. Northridge (Eds.), The health of sexual minorities (pp. 242-267). New York, NY: Springer.

Meyer, I. \& Dean, L. (1998). Internalized homophobia, intimacy and sexual behaviour among gay and bisexual men. In Herek, G. (ed.), Stigma and Sexual Orientation. pp. 160-186. Sage, Thousand Oaks, CA.

Meyer, I. H., Schwartz, S., \& Frost, D. M. (2008). Social patterning of stress and coping: Does disadvantaged social status confer more stress and fewer coping resources? Social Science \& Medicine (1982), 67(3), 368-379.

Mohr, J. J., \& Fassinger, R. (2000). Measuring dimensions of lesbian and gay male experience. Measurement and Evaluation in Counseling and Development, 33, $66-90$.

Mohr, J. J., \& Fassinger, R. E. (2006). Sexual orientation identity and romantic relationship quality in same-sex couples. Personality and Social Psychology Bulletin, 32(8), 1085-1099.

Mohr, J. J. \& Kendra, M. S. (2011). Revision and extension of a multidimensional measure of sexual minority identity: The Lesbian, Gay, and Bisexual Identity Scale. Journal of Counseling Psychology, 58, 234-245.

Moradi, B., Mohr, J. J., Worthington, R. L., \& Fassinger, R. E. (2009). Counseling psychology research on sexual (orientation) minority issues: Conceptual and methodological challenges and opportunities. Journal of Counseling Psychology, $56,5-22$. 
Morris, J. F. \& Rothblum, E. D. (1999). Who fills out a "lesbian" questionnaire? The interrelationship of sexual orientation, years "out," disclosure of sexual orientation, sexual experience with women, and participation in the lesbian community. Psychology of Women Quarterly, 23, 537-557.

Mossakowski, K. N. (2003). Coping with perceived discrimination: Does ethnic identity protect mental health, Journal of Health and Social Behavior, 44, 318-331.

Mustanski, B, Newcomb, M., \& Garofalo, R. (2011). Mental health of lesbian, gay, and bisexual youth: A developmental resiliency perspective. Journal of Gay and Lesbian Social Services, 23,204-225.

Nadal, K. L. (2008). Preventing racial, ethnic, gender, sexual minority, disability, and religious microaggressions: Recommendations for promoting positive mental health. Prevention in Counseling Psychology: Theory, Research, Practice and Training, 2(1), 22-27.

Nadal, K. L., Rivera, D. P., \& Corpus, M. J. H. (2010) Sexual orientation and transgender microaggressions in everyday life: Experiences of lesbians, gays, bisexuals, and transgender individuals. In D. W. Sue (Ed.), Microaggressions and Marginality: Manifestation, Dynamics, and Impact (pp. 217-240). New York: Wiley.

Nadal, K. L., Issa, M., Leon, J., Meterko, V., Wideman, M., \& Wong, Y. (2011a). Sexual orientation microaggressions: "Death by a thousand cuts" for lesbian, gay, and bisexual youth. Journal of LGBT Youth, 8, 234-259.

Nadal, K. L., Wong, Y., Issa, M., Meterko, V., Leon, J., \& Wideman, M. (2011b). Sexual orientation microaggressions: Processes and coping mechanisms for lesbian, gay, and bisexual individuals. Journal of LGBT Issues in Counseling, 5(1), 21-46. 
Nadal, K. L., Davidoff, K. C., Davis, L. S., \& Wong, Y. (2014). Emotional, behavioral, and cognitive reactions to microaggressions: Transgender perspectives. Psychology of Sexual Orientation and Gender Diversity, 1, 72-81

Nadal, K. L., Griffin, K. E., Wong, Y., Hamit, S. and Rasmus, M. (2014). The impact of racial microaggressions on mental health: Counseling implications for clients of color. Journal of Counseling \& Development, 92, 57-66.

Nadal, K. L., Whitman, C. N., Davis, L. S., Erazo, T., \& Davidoff, K. C. (2016). Microaggressions toward lesbian, gay, bisexual, transgender, queer, and genderqueer people: A review of the literature. The Journal of Sex Research, 53, 488-508.

Neblett, E.W., Jr., Shelton, J.N., \& Sellers, R.M. (2004). The role of racial identity in managing daily racial hassles. In G. Philogène (Ed.), Racial identity in context: The legacy of Kenneth B. Clark. Decade of behavior. Washington, DC: American Psychological Association.

Newcomb, M. E., \& Mustanski, B. (2010). Internalized homophobia and internalizing mental health problems: A meta-analytic review. Clinical Psychology Review, 30(8), 1019-1029.

Orne, J. (2011). 'You will always have to "out” yourself': Reconsidering coming out through strategic outness. Sexualities, 14, 681-703.

Pachankis, J. E. (2008). The psychological implications of concealing a stigma: A cognitive-affective-behavioral model. Psychological Bulletin, 133, 328-345.

Park, I. K., Schwartz, S. J., Lee, R. M., Kim, M., \& Rodriguez, L. (2013). Perceived racial/ethnic discrimination and antisocial behaviors among Asian American 
college students: Testing the moderating roles of ethnic and American identity. Cultural Diversity and Ethnic Minority Psychology, 19(2), 166-176.

Pew Research Center. (2013). A Survey of LGBT Americans: Attitudes, Experiences, and Values in Changing Times. Retrieved July 30, 2018, from http://assets.pewresearch.org/wp-content/uploads/sites/3/2013/06/SDT_LGBTAmericans_06-2013.pdf.

Phinney, J. (1992). The Multigroup Ethnic Identity Measure: A new scale for use with adolescents and young adults from diverse groups. Journal of Adolescent Research, 7, 156-176.

Pierce, C. (1974). Psychiatric Problems of the Black Minority. In S. Arieti (Ed.). American handbook of psychiatry (pp. 512-523). New York: Basic Books.

Platt, L. F. \& Lenzen, A. L. (2013). Sexual orientation microaggressions and the experience of sexual minorities. Journal of Homosexuality, 60, 1011-1034.

Quinn, D. M., \& Chaudoir, S. R. (2009). Living with a concealable stigmatized identity: The impact of anticipated stigma, centrality, salience, and cultural stigma on psychological distress and health. Journal of Personality and Social Psychology, 97(4), 634-651.

Radloff, L.S. (1977). The CES-D Scale: A self-report depression scale for research in the general population. Applied Psychological Measurement, 1, 385-401.

Riggle, E. D. B., Mohr, J. J., Rostosky, S. S., Fingerhut, A. W., \& Balsam, K. F. (2014). A multifactor lesbian, gay, and bisexual positive identity measure (LGB-PIM). Psychology of Sexual Orientation and Gender Diversity, 1, 398-411. 
Riggle, E. D. B., \& Rostosky, S. S. (2012). A positive view of LGBTQ: Embracing identity and cultivating well-being. Lanham, MD: Rowman \& Littlefield.

Romero, A. J. \& Roberts, R. E. (2003). The impact of multiple dimensions of ethnic identity on discrimination and adolescents' self-esteem. Journal of Applied Social Psychology, 33, 2288-2305.

Rosario, M., Schrimshaw, E. W., \& Hunter, J. (2008). Ethnic/racial disparities in gayrelated stress and health among lesbian, gay and bisexual youths: Examining a prevalent hypothesis. In B.C. Wallace (Ed.), Toward equity in health: A new global approach to health disparities (pp. 427-446). New York: Springer.

Rosenberg, M. (1965). Society and the adolescent self-image. Princeton, NJ: Princeton University Press.

Russell, G. M. \& Richards, J. A. (2003). Stressors and resilience factors for lesbians, gay men, and bisexuals confronting antigay politics. American Journal of Community Psychology, 31,313-328.

Sarno, E., \& Wright, A. J. (2013). Homonegative microaggressions and identity in bisexual men and women. Journal of Bisexuality, 13(1), 63-81.

Sell, R. L. (1996). The Sell Assessment of Sexual Orientation: Background and scoring. Journal of Gay, Lesbian, and Bisexual Identity, 1, 295-310.

Sellers, R. M., Rowley, S. A., Chavous, T. M., Shelton, J. N., \& Smith, M. A. (1997). Multidimensional Inventory of Black Identity: Preliminary investigation of reliability and construct validity. Journal of Personality and Social Psychology, 73, 805-815. 
Sellers, R. M. \& Shelton, J. N. (2003). The role of racial identity in perceived discrimination. Journal of Personality and Social Psychology, 84, 1079-1092.

Shepard, B. (2009). Queer Political Performance and Protest. New York: Routledge.

Sherbourne, C. D., \& Stewart, A. L. (1991). The MOS Social Support Survey. Social Science \& Medicine, 32, 705-714.

Silverschanz, P., Cortina, L. M., Konik, J., \& Magley, V. J. (2008). Slurs, snubs, and queer jokes: Incidence and impact of heterosexist harassment in academia. Sex Roles, 58, 179-191.

Solorzano, D., Ceja, M., \& Yosso, T. (2000). Critical race theory, racial microaggressions, and campus racial climate: The experiences of African American college ctudents. Journal of Negro Education, 69, 60-73.

Spencer, S. M., \& Patrick, J. H. (2009). Social support and personal mastery as protective resources during emerging adulthood. Journal of Adult Development, 16(4), 191198.

Spitzer, R. L., Kroenke, K., Williams, J. B., \& Löwe, B. (2006). A brief measure for assessing generalized anxiety disorder: The GAD-7. Archives of Internal Medicine, 166, 1092-1097.

Sue, D. W., Capodilupo, C. M., Torino, G. C., Bucceri, J. M., Holder, A. M. B., Nadal, K. L., \& Esquilin, M. (2007). Racial microaggressions in everyday life: Implications for clinical practice. American Psychologist, 62(4), 271-286.

Sue, D. W., Bucceri, J., Lin, A. I., Nadal, K. L., \& Torino, G. C. (2009). Racial microaggressions and the Asian American experience. Asian American Journal of Psychology, S(1), 88-101. 
Sue, D. W. (2010). Microaggressions in everyday life: Race, gender, and sexual orientation. Hoboken, N.J: Wiley.

Sue, D. W., Rivera, D. P., Watkins, N. L., Kim, R. H., Kim, S., \& Williams, C. D. (2011). Racial dialogues: Challenges faculty of color face in the classroom. Cultural Diversity and Ethnic Minority Psychology, 17(3), 331-340.

Swann, S.K. \& Spivey, C.A. (2004). The relationship between self-esteem and lesbian identity during adolescence. Child and Adolescent Social Work Journal, 21, 629646.

Szymanski, D. M., \& Carr, E. R. (2008). The roles of gender role conflict and internalized heterosexism in gay and bisexual men's psychological distress: Testing two mediation models. Psychology of Men \& Masculinity, 9(1), 40-54.

Torres, L., Yznaga, S. D., \& Moore, K. M. (2011). Discrimination and Latino psychological distress: The moderating role of ethnic identity exploration and commitment. American Journal of Orthopsychiatry, 81(4), 526-534.

Troiden, R. R. (1993). The formation of homosexual identities. In L. D. Garnets \& D. C. Kimmel (Eds.), Between men—between women: Lesbian and gay studies. Psychological perspectives on lesbian and gay male experiences (pp. 191-217). New York, NY, US: Columbia University Press. (Reprinted in modified form from "Journal of Homosexuality," 17(1/2), 1989, pp. 43-73)

Umaña-Taylor, A. J., Updegraff, K. A., \& Gonzales-Backen, M. A. (2011). Mexicanorigin adolescent mothers' stressors and psychosocial functioning: Examining ethnic identity affirmation and familism as moderators. Journal of Youth and Adolescence, 40(2), 140-157. 
U. S. Department of Justice, Federal Bureau of Investigation (2009). Hate Crimes Statistics. Washington, DC: Government Printing Office.

Wang, Y.P. and Gorenstein, C. (2013) Psychometric properties of the Beck Depression Inventory-II: A comprehensive review. Revista Brasileira de Psiquiatria, 35, 416431.

Weinberg, M.S., \& Williams, C.J. (1974). Male homosexuals: Their problems and adaptations. New York: Oxford University Press.

Whitbeck, L. B., Mansoo, Y., Johnson, K. D., Hoyt, D. R., \& Walls, M. L. (2008). Diagnostic prevalence rates from early to mid-adolescence among indigenous adolescents: First results from a longitudinal study. Journal of American Academy Child Adolescent Psychiatry, 47, 890-900

Williams, T., Connolly, J., Pepler, D., \& Craig, W. (2005). Peer victimization, social support, and psychosocial adjustment of sexual minority adolescents. Journal of Youth and Adolescence, 34, 471-482.

Woodford, M. R., Chonody, J. M., Kulick, A., Brennan, D. J., \& Renn, K. (2015). The LGBQ Microaggressions on Campus Scale: A scale development and validation study. Journal of Homosexuality, 62, 1660-1687.

Woodford, M. R., Kulick, A., Sinco, B. R., \& Hong, J. S. (2014). Contemporary heterosexism on campus and psychological distress among LGBQ students: The mediating role of self-acceptance. American Journal of Orthopsychiatry, 84, 519529. 
Wright, A. J. \& Wegner, R. T. (2012). Homonegative microaggressions and their impact on LGB individuals: A measure validity study. Journal of LGBT Issues in Counseling, 6, 34-54.

Zoeterman, S. E. \& Wright, A. J. (2014). The role of openness to experience and sexual identity formation in LGB individuals: Implications for mental health. Journal of Homosexuality. 61, 334-353. 
Appendix A: Measures

Demographics Information

1. Age

2. What is your sexual orientation?

Gay

Lesbian

Bisexual __ Other

3 . What is your gender identity?

Female Male Non-binary/ third gender Prefer to self-describe Prefer not to say

4. Number of years of formal education

5. What is your total estimated household income?

Less than $\$ 10,000$

$\$ 10,000$ to $\$ 19,999$

$\$ 20,000$ to $\$ 29,999$

$\$ 30,000$ to $\$ 39,999$

$\$ 40,000$ to $\$ 49,999$

$\$ 50,000$ to $\$ 59,999$

$\$ 60,000$ to $\$ 69,999$

$\$ 70,000$ to $\$ 79,999$

$\$ 80,000$ to $\$ 89,999$

$\$ 90,000$ to $\$ 99,999$

$\$ 100,000$ to $\$ 149,999$

$\$ 150,000$ or more

6. Please choose one or more categories that you feel best fits your ethnic identification:

African American Asian American Asian American (South Asian) Hispanic/Latino(a) Middle Eastern Polynesian Jewish Mediterranean Eastern European Scandinavian Other/multiracial (please Western European Native American specify):

7. City, State where spent most of life prior to age 18 :

8. Relationship Status:

Married/partnered

Divorced

Separated

Single 
Lesbian, Gay, and Bisexual Identity Scale

For each of the following questions, please mark the response that best indicates your current experience as an LGB person. Please be as honest as possible: Indicate how you really feel now, not how you think you should feel. There is no need to think too much about any one question. Answer each question according to your initial reaction and then move on to the next.

\begin{tabular}{|l|l|l|l|l|l|l|}
\hline & $\begin{array}{l}\text { Disagree } \\
\text { Strongly }\end{array}$ & Disagree & $\begin{array}{l}\text { Disagree } \\
\text { Somewh } \\
\text { at }\end{array}$ & $\begin{array}{l}\text { Agree } \\
\text { Somewh } \\
\text { at }\end{array}$ & Agree & $\begin{array}{l}\text { Agree } \\
\text { Strongly }\end{array}$ \\
\hline $\begin{array}{l}\text { 1. I prefer to keep my same-sex } \\
\text { romantic relationships rather } \\
\text { private. }\end{array}$ & 1 & 2 & 3 & 4 & 5 & 6 \\
\hline $\begin{array}{l}\text { 2. If it were possible, I would } \\
\text { choose to be straight. }\end{array}$ & 1 & 2 & 3 & 4 & 5 & 6 \\
\hline $\begin{array}{l}\text { 3. I'm not totally sure what my } \\
\text { sexual orientation is. }\end{array}$ & 1 & 2 & 3 & 4 & 5 & 6 \\
\hline $\begin{array}{l}\text { 4. I keep careful control over } \\
\text { who knows about my same-sex } \\
\text { romantic relationships. }\end{array}$ & 1 & 2 & 3 & 4 & 5 & 6 \\
\hline $\begin{array}{l}\text { 5. I often wonder whether } \\
\text { others judge me for my sexual } \\
\text { orientation. }\end{array}$ & 1 & 2 & 3 & 4 & 5 & 6 \\
\hline $\begin{array}{l}\text { 6. I am glad to be an LGB } \\
\text { person. }\end{array}$ & 1 & 2 & 3 & 4 & 5 & 6 \\
\hline $\begin{array}{l}\text { 7. I look down on } \\
\text { heterosexuals. }\end{array}$ & 1 & 2 & 3 & 4 & 5 & 6 \\
\hline $\begin{array}{l}\text { 8. I keep changing my mind } \\
\text { about my sexual orientation. }\end{array}$ & 1 & 2 & 3 & 4 & 5 & 6 \\
\hline $\begin{array}{l}\text { 9. I can't feel comfortable } \\
\text { knowing that others judge me } \\
\text { negatively for my sexual } \\
\text { orientation. }\end{array}$ & 1 & 2 & 3 & 4 & 5 & 6 \\
\hline $\begin{array}{l}\text { 10. I feel that LGB people are } \\
\text { superior to heterosexuals. }\end{array}$ & 1 & 2 & 3 & 4 & 5 & 6 \\
\hline $\begin{array}{l}\text { 11. My sexual orientation is an } \\
\text { insignificant part of who I am }\end{array}$ & 1 & 2 & 3 & 4 & 5 & 6 \\
\hline $\begin{array}{l}\text { 12. Admitting to myself that } \\
\text { I'm an LGB person has been a } \\
\text { very painful process. }\end{array}$ & 1 & 2 & 3 & 4 & 5 & 6 \\
\hline $\begin{array}{l}\text { 13. I'm proud to be part of the } \\
\text { LGB community. }\end{array}$ & 1 & 2 & 3 & 4 & 5 & 6 \\
\hline $\begin{array}{l}\text { 14. I can't decide whether I am } \\
\text { bisexual or homosexual }\end{array}$ & 1 & 2 & 3 & 4 & 5 & 6 \\
\hline
\end{tabular}




\begin{tabular}{|l|l|l|l|l|l|l|}
\hline $\begin{array}{l}\text { 15. My sexual orientation is a } \\
\text { central part of my identity. }\end{array}$ & 1 & 2 & 3 & 4 & 5 & 6 \\
\hline $\begin{array}{l}\text { 16. I think a lot about how my } \\
\text { sexual orientation affects the } \\
\text { way people see me. }\end{array}$ & 1 & 2 & 3 & 4 & 5 & 6 \\
\hline $\begin{array}{l}\text { 17. Admitting to myself that } \\
\text { I'm an LGB person has been a } \\
\text { very slow process. }\end{array}$ & 1 & 2 & 3 & 4 & 5 & 6 \\
\hline $\begin{array}{l}\text { 18. Straight people have boring } \\
\text { lives compared with LGB } \\
\text { people. }\end{array}$ & 1 & 2 & 3 & 4 & 5 & 6 \\
\hline $\begin{array}{l}\text { 19. My sexual orientation is a } \\
\text { very personal and private } \\
\text { matter. }\end{array}$ & 1 & 2 & 3 & 4 & 5 & 6 \\
\hline 20. I wish I were heterosexual. & 1 & 2 & 3 & 4 & 5 & 6 \\
\hline $\begin{array}{l}\text { 21. To understand who I am as } \\
\text { a person, you have to know that } \\
\text { I'm LGB. }\end{array}$ & 1 & 2 & 3 & 4 & 5 & 6 \\
\hline $\begin{array}{l}\text { 22. I get very confused when I } \\
\text { try to figure out my sexual } \\
\text { orientation. }\end{array}$ & 1 & 2 & 3 & 4 & 5 & 6 \\
\hline $\begin{array}{l}\text { 23. I have felt comfortable with } \\
\text { my sexual identity just about } \\
\text { from the start. }\end{array}$ & 1 & 2 & 3 & 4 & 5 & 6 \\
\hline $\begin{array}{l}\text { 24. Being an LGB person is a } \\
\text { very important aspect of my } \\
\text { life. }\end{array}$ & 1 & 2 & 3 & 4 & 5 & 6 \\
\hline $\begin{array}{l}\text { 25. I believe being LGB is an } \\
\text { important part of me. }\end{array}$ & 1 & 2 & 3 & 4 & 5 & 6 \\
\hline 26. I am proud to be LGB. & 1 & 2 & 3 & 4 & 5 & 6 \\
\hline $\begin{array}{l}\text { 27. I believe it is unfair that I } \\
\text { am attracted to people of the } \\
\text { same sex. }\end{array}$ & 1 & 2 & 3 & 4 & 5 & 6 \\
\hline
\end{tabular}




\section{Homonegative Microaggressions Scale}

The following questions ask you about experiences you've had in the recent past (the past 6 months).

1. How often have people conveyed that it is your choice to be gay?

\begin{tabular}{|l|l|l|l|l|l|l|}
\hline & $\begin{array}{l}\text { Hardly ever/ } \\
\text { never/ not at } \\
\text { all }\end{array}$ & $\begin{array}{l}\text { Occasionally, } \\
\text { but rarely/a } \\
\text { little bit }\end{array}$ & $\begin{array}{l}\text { Occasionally/ } \\
\text { from time to } \\
\text { time/somewhat }\end{array}$ & $\begin{array}{l}\text { Consistently/ } \\
\text { often/ a good } \\
\text { deal }\end{array}$ & $\begin{array}{l}\text { Consistently/ } \\
\text { a great deal }\end{array}$ & $\begin{array}{l}\text { Not } \\
\text { applicable }\end{array}$ \\
\hline $\begin{array}{l}\text { In the } \\
\text { past 6 } \\
\text { months: }\end{array}$ & & & & & & \\
\hline
\end{tabular}

2. How often have people acted as if you have not come out?

\begin{tabular}{|l|l|l|l|l|l|l|}
\hline & $\begin{array}{l}\text { Hardly ever/ } \\
\text { never/ not at } \\
\text { all }\end{array}$ & $\begin{array}{l}\text { Occasionally, } \\
\text { but rarely/a } \\
\text { little bit }\end{array}$ & $\begin{array}{l}\text { Occasionally/ } \\
\text { from time to } \\
\text { time/somewhat }\end{array}$ & $\begin{array}{l}\text { Consistently/ } \\
\text { often/ a good } \\
\text { deal }\end{array}$ & $\begin{array}{l}\text { Consistently/ } \\
\text { a great deal }\end{array}$ & $\begin{array}{l}\text { Not } \\
\text { applicable }\end{array}$ \\
\hline $\begin{array}{l}\text { In the } \\
\text { past 6 } \\
\text { months: }\end{array}$ & & & & & & \\
\hline
\end{tabular}

3. How often have people asked about former boyfriends (if you are a woman) or girlfriends (if you are a man)?

\begin{tabular}{|l|l|l|l|l|l|l|}
\hline & $\begin{array}{l}\text { Hardly ever/ } \\
\text { never/ not at } \\
\text { all }\end{array}$ & $\begin{array}{l}\text { Occasionally, } \\
\text { but rarely/a } \\
\text { little bit }\end{array}$ & $\begin{array}{l}\text { Occasionally/ } \\
\text { from time to } \\
\text { time/somewhat }\end{array}$ & $\begin{array}{l}\text { Consistently/ } \\
\text { often/ a good } \\
\text { deal }\end{array}$ & $\begin{array}{l}\text { Consistently/ } \\
\text { a great deal }\end{array}$ & $\begin{array}{l}\text { Not } \\
\text { applicable }\end{array}$ \\
\hline $\begin{array}{l}\text { In the } \\
\text { past 6 } \\
\text { months: }\end{array}$ & & & & & & \\
\hline
\end{tabular}

4. How often have people assumed you are straight?

\begin{tabular}{|l|l|l|l|l|l|l|}
\hline & $\begin{array}{l}\text { Hardly ever/ } \\
\text { never/ not at } \\
\text { all }\end{array}$ & $\begin{array}{l}\text { Occasionally, } \\
\text { but rarely/a } \\
\text { little bit }\end{array}$ & $\begin{array}{l}\text { Occasionally/ } \\
\text { from time to } \\
\text { time/somewhat }\end{array}$ & $\begin{array}{l}\text { Consistently/ } \\
\text { often/ a good } \\
\text { deal }\end{array}$ & $\begin{array}{l}\text { Consistently/ } \\
\text { a great deal }\end{array}$ & $\begin{array}{l}\text { Not } \\
\text { applicable }\end{array}$ \\
\hline $\begin{array}{l}\text { In the } \\
\text { past 6 } \\
\text { months: }\end{array}$ & & & & & & \\
\hline
\end{tabular}

5. How often have people used the phrase "sexual preference" instead of"sexual orientation"?

\begin{tabular}{|l|l|l|l|l|l|l|}
\hline & $\begin{array}{l}\text { Hardly ever/ } \\
\text { never/ not at } \\
\text { all }\end{array}$ & $\begin{array}{l}\text { Occasionally, } \\
\text { but rarely/a } \\
\text { little bit }\end{array}$ & $\begin{array}{l}\text { Occasionally/ } \\
\text { from time to } \\
\text { time/somewhat }\end{array}$ & $\begin{array}{l}\text { Consistently/ } \\
\text { often/a good } \\
\text { deal }\end{array}$ & $\begin{array}{l}\text { Consistently/ } \\
\text { a great deal }\end{array}$ & $\begin{array}{l}\text { Not } \\
\text { applicable }\end{array}$ \\
\hline $\begin{array}{l}\text { In the } \\
\text { past 6 } \\
\text { months: }\end{array}$ & & & & & & \\
\hline
\end{tabular}


6. How often have people assumed you were more sensitive (if you are a man) or less sensitive (if you are a woman) than you are?

\begin{tabular}{|l|l|l|l|l|l|l|}
\hline & $\begin{array}{l}\text { Hardly ever/ } \\
\text { never/ not at } \\
\text { all }\end{array}$ & $\begin{array}{l}\text { Occasionally, } \\
\text { but rarely/a } \\
\text { little bit }\end{array}$ & $\begin{array}{l}\text { Occasionally/ } \\
\text { from time to } \\
\text { time/somewhat }\end{array}$ & $\begin{array}{l}\text { Consistently/ } \\
\text { often/ a good } \\
\text { deal }\end{array}$ & $\begin{array}{l}\text { Consistently/ } \\
\text { a great deal }\end{array}$ & $\begin{array}{l}\text { Not } \\
\text { applicable }\end{array}$ \\
\hline $\begin{array}{l}\text { In the } \\
\text { past 6 } \\
\text { months: }\end{array}$ & & & & & & \\
\hline
\end{tabular}

7. How often have people assumed you were skilled in stereotypically gay tasks (like interior design for men or carpentry for women)?

\begin{tabular}{|l|l|l|l|l|l|l|}
\hline & $\begin{array}{l}\text { Hardly ever/ } \\
\text { never/ not at } \\
\text { all }\end{array}$ & $\begin{array}{l}\text { Occasionally, } \\
\text { but rarely/a } \\
\text { little bit }\end{array}$ & $\begin{array}{l}\text { Occasionally/ } \\
\text { from time to } \\
\text { time/somewhat }\end{array}$ & $\begin{array}{l}\text { Consistently/ } \\
\text { often/ a good } \\
\text { deal }\end{array}$ & $\begin{array}{l}\text { Consistently/ } \\
\text { a great deal }\end{array}$ & $\begin{array}{l}\text { Not } \\
\text { applicable }\end{array}$ \\
\hline $\begin{array}{l}\text { In the } \\
\text { past 6 } \\
\text { months: }\end{array}$ & & & & & & \\
\hline
\end{tabular}

8. How often have people assumed you knew a lot about stereotypical LGB interests like wine (if you are a man) or sports (if you are a woman)?

\begin{tabular}{|l|l|l|l|l|l|l|}
\hline & $\begin{array}{l}\text { Hardly ever/ } \\
\text { never/ not at } \\
\text { all }\end{array}$ & $\begin{array}{l}\text { Occasionally, } \\
\text { but rarely/a } \\
\text { little bit }\end{array}$ & $\begin{array}{l}\text { Occasionally/ } \\
\text { from time to } \\
\text { time/somewhat }\end{array}$ & $\begin{array}{l}\text { Consistently/ } \\
\text { often/ a good } \\
\text { deal }\end{array}$ & $\begin{array}{l}\text { Consistently/ } \\
\text { a great deal }\end{array}$ & $\begin{array}{l}\text { Not } \\
\text { applicable }\end{array}$ \\
\hline $\begin{array}{l}\text { In the } \\
\text { past 6 } \\
\text { months: }\end{array}$ & & & & & & \\
\hline
\end{tabular}

9. How often have people assumed you were knowledgeable about women's clothing (if you are a man) or men's clothing (if you are a woman)?

\begin{tabular}{|l|l|l|l|l|l|l|}
\hline & $\begin{array}{l}\text { Hardly ever/ } \\
\text { never/ not at } \\
\text { all }\end{array}$ & $\begin{array}{l}\text { Occasionally, } \\
\text { but rarely/a } \\
\text { little bit }\end{array}$ & $\begin{array}{l}\text { Occasionally/ } \\
\text { from time to } \\
\text { time/somewhat }\end{array}$ & $\begin{array}{l}\text { Consistently/ } \\
\text { often/ a good } \\
\text { deal }\end{array}$ & $\begin{array}{l}\text { Consistently/ } \\
\text { a great deal }\end{array}$ & $\begin{array}{l}\text { Not } \\
\text { applicable }\end{array}$ \\
\hline $\begin{array}{l}\text { In the } \\
\text { past 6 } \\
\text { months: }\end{array}$ & & & & & & \\
\hline
\end{tabular}

10. How often have people of the same sex assumed you were attracted to them simply because of your sexual orientation?

\begin{tabular}{|l|l|l|l|l|l|l|}
\hline & $\begin{array}{l}\text { Hardly ever/ } \\
\text { never/ not at } \\
\text { all }\end{array}$ & $\begin{array}{l}\text { Occasionally, } \\
\text { but rarely/a } \\
\text { little bit }\end{array}$ & $\begin{array}{l}\text { Occasionally/ } \\
\text { from time to } \\
\text { time/somewhat }\end{array}$ & $\begin{array}{l}\text { Consistently/ } \\
\text { often/a good } \\
\text { deal }\end{array}$ & $\begin{array}{l}\text { Consistently/ } \\
\text { a great deal }\end{array}$ & $\begin{array}{l}\text { Not } \\
\text { applicable }\end{array}$ \\
\hline $\begin{array}{l}\text { In the } \\
\text { past } 6 \\
\text { months: }\end{array}$ & & & & & & \\
\hline
\end{tabular}


11. How often have people told you they just see you as a person, regardless of your sexual orientation?

\begin{tabular}{|l|l|l|l|l|l|l|}
\hline & $\begin{array}{l}\text { Hardly ever/ } \\
\text { never/ not at } \\
\text { all }\end{array}$ & $\begin{array}{l}\text { Occasionally, } \\
\text { but rarely/a } \\
\text { little bit }\end{array}$ & $\begin{array}{l}\text { Occasionally/ } \\
\text { from time to } \\
\text { time/somewhat }\end{array}$ & $\begin{array}{l}\text { Consistently/ } \\
\text { often/ a good } \\
\text { deal }\end{array}$ & $\begin{array}{l}\text { Consistently/ } \\
\text { a great deal }\end{array}$ & $\begin{array}{l}\text { Not } \\
\text { applicable }\end{array}$ \\
\hline $\begin{array}{l}\text { In the } \\
\text { past 6 } \\
\text { months: }\end{array}$ & & & & & & \\
\hline
\end{tabular}

12. How often have people said blanket statements about how society is full of diversity, minimizing your experience of being different?

\begin{tabular}{|l|l|l|l|l|l|l|}
\hline & $\begin{array}{l}\text { Hardly ever/ } \\
\text { never/ not at } \\
\text { all }\end{array}$ & $\begin{array}{l}\text { Occasionally, } \\
\text { but rarely/a } \\
\text { little bit }\end{array}$ & $\begin{array}{l}\text { Occasionally/ } \\
\text { from time to } \\
\text { time/somewhat }\end{array}$ & $\begin{array}{l}\text { Consistently/ } \\
\text { often/ a good } \\
\text { deal }\end{array}$ & $\begin{array}{l}\text { Consistently/ } \\
\text { a great deal }\end{array}$ & $\begin{array}{l}\text { Not } \\
\text { applicable }\end{array}$ \\
\hline $\begin{array}{l}\text { In the } \\
\text { past 6 } \\
\text { months: }\end{array}$ & & & & & & \\
\hline
\end{tabular}

13. How often have family members simply ignored the fact that you are a LGB individual?

\begin{tabular}{|l|l|l|l|l|l|l|}
\hline & $\begin{array}{l}\text { Hardly ever/ } \\
\text { never/ not at } \\
\text { all }\end{array}$ & $\begin{array}{l}\text { Occasionally, } \\
\text { but rarely/a } \\
\text { little bit }\end{array}$ & $\begin{array}{l}\text { Occasionally/ } \\
\text { from time to } \\
\text { time/somewhat }\end{array}$ & $\begin{array}{l}\text { Consistently/ } \\
\text { often/ a good } \\
\text { deal }\end{array}$ & $\begin{array}{l}\text { Consistently/ } \\
\text { a great deal }\end{array}$ & $\begin{array}{l}\text { Not } \\
\text { applicable }\end{array}$ \\
\hline $\begin{array}{l}\text { In the } \\
\text { past 6 } \\
\text { months: }\end{array}$ & & & & & & \\
\hline
\end{tabular}

14. How often have people changed the subject/topic when reference to your sexual orientation comes up?

\begin{tabular}{|l|l|l|l|l|l|l|}
\hline & $\begin{array}{l}\text { Hardly ever/ } \\
\text { never/ not at } \\
\text { all }\end{array}$ & $\begin{array}{l}\text { Occasionally, } \\
\text { but rarely/a } \\
\text { little bit }\end{array}$ & $\begin{array}{l}\text { Occasionally/ } \\
\text { from time to } \\
\text { time/somewhat }\end{array}$ & $\begin{array}{l}\text { Consistently/ } \\
\text { often/a good } \\
\text { deal }\end{array}$ & $\begin{array}{l}\text { Consistently/ } \\
\text { a great deal }\end{array}$ & $\begin{array}{l}\text { Not } \\
\text { applicable }\end{array}$ \\
\hline $\begin{array}{l}\text { In the } \\
\text { past 6 } \\
\text { months: }\end{array}$ & & & & & & \\
\hline
\end{tabular}

15. How often have people assumed you were a pervert or deviant?

\begin{tabular}{|l|l|l|l|l|l|l|}
\hline & $\begin{array}{l}\text { Hardly ever/ } \\
\text { never/ not at } \\
\text { all }\end{array}$ & $\begin{array}{l}\text { Occasionally, } \\
\text { but rarely/a } \\
\text { little bit }\end{array}$ & $\begin{array}{l}\text { Occasionally/ } \\
\text { from time to } \\
\text { time/somewhat }\end{array}$ & $\begin{array}{l}\text { Consistently/ } \\
\text { often/ a good } \\
\text { deal }\end{array}$ & $\begin{array}{l}\text { Consistently/ } \\
\text { a great deal }\end{array}$ & $\begin{array}{l}\text { Not } \\
\text { applicable }\end{array}$ \\
\hline $\begin{array}{l}\text { In the } \\
\text { past 6 } \\
\text { months: }\end{array}$ & & & & & & \\
\hline
\end{tabular}

16. How often have people assumed you were a pedophile?

\begin{tabular}{|l|l|l|l|l|l|l|}
\hline & $\begin{array}{l}\text { Hardly ever/ } \\
\text { never/ not at } \\
\text { all }\end{array}$ & $\begin{array}{l}\text { Occasionally, } \\
\text { but rarely/a } \\
\text { little bit }\end{array}$ & $\begin{array}{l}\text { Occasionally/ } \\
\text { from time to } \\
\text { time/somewhat }\end{array}$ & $\begin{array}{l}\text { Consistently/ } \\
\text { often/ a good } \\
\text { deal }\end{array}$ & $\begin{array}{l}\text { Consistently/ } \\
\text { a great deal }\end{array}$ & $\begin{array}{l}\text { Not } \\
\text { applicable }\end{array}$ \\
\hline
\end{tabular}




\begin{tabular}{|l|l|l|l|l|l|}
\hline In the & & & & & \\
past 6 & & & & & \\
months: & & & & & \\
\hline
\end{tabular}

17. How often have people assumed you have HIV/AIDS because of your sexual orientation?

\begin{tabular}{|l|l|l|l|l|l|l|}
\hline & $\begin{array}{l}\text { Hardly ever/ } \\
\text { never/ not at } \\
\text { all }\end{array}$ & $\begin{array}{l}\text { Occasionally, } \\
\text { but rarely/a } \\
\text { little bit }\end{array}$ & $\begin{array}{l}\text { Occasionally/ } \\
\text { from time to } \\
\text { time/somewhat }\end{array}$ & $\begin{array}{l}\text { Consistently/ } \\
\text { often/ a good } \\
\text { deal }\end{array}$ & $\begin{array}{l}\text { Consistently/ } \\
\text { a great deal }\end{array}$ & $\begin{array}{l}\text { Not } \\
\text { applicable }\end{array}$ \\
\hline $\begin{array}{l}\text { In the } \\
\text { past 6 } \\
\text { months: }\end{array}$ & & & & & & \\
\hline
\end{tabular}

18. How often have people assumed you are sexually promiscuous because of your sexual orientation?

\begin{tabular}{|l|l|l|l|l|l|l|}
\hline & $\begin{array}{l}\text { Hardly ever/ } \\
\text { never/ not at } \\
\text { all }\end{array}$ & $\begin{array}{l}\text { Occasionally, } \\
\text { but rarely/a } \\
\text { little bit }\end{array}$ & $\begin{array}{l}\text { Occasionally/ } \\
\text { from time to } \\
\text { time/somewhat }\end{array}$ & $\begin{array}{l}\text { Consistently/ } \\
\text { often/ a good } \\
\text { deal }\end{array}$ & $\begin{array}{l}\text { Consistently/ } \\
\text { a great deal }\end{array}$ & $\begin{array}{l}\text { Not } \\
\text { applicable }\end{array}$ \\
\hline $\begin{array}{l}\text { In the } \\
\text { past } 6 \\
\text { months: }\end{array}$ & & & & & & \\
\hline
\end{tabular}

19. How often have people physically shielded their child/children from you?

\begin{tabular}{|l|l|l|l|l|l|l|}
\hline & $\begin{array}{l}\text { Hardly ever/ } \\
\text { never/ not at } \\
\text { all }\end{array}$ & $\begin{array}{l}\text { Occasionally, } \\
\text { but rarely/a } \\
\text { little bit }\end{array}$ & $\begin{array}{l}\text { Occasionally/ } \\
\text { from time to } \\
\text { time/somewhat }\end{array}$ & $\begin{array}{l}\text { Consistently/ } \\
\text { often/ a good } \\
\text { deal }\end{array}$ & $\begin{array}{l}\text { Consistently/ } \\
\text { a great deal }\end{array}$ & $\begin{array}{l}\text { Not } \\
\text { applicable }\end{array}$ \\
\hline $\begin{array}{l}\text { In the } \\
\text { past 6 } \\
\text { months: }\end{array}$ & & & & & & \\
\hline
\end{tabular}

20. How often have people avoided proximity, like crossing the street to walk or waiting for the next elevator?

\begin{tabular}{|l|l|l|l|l|l|l|}
\hline & $\begin{array}{l}\text { Hardly ever/ } \\
\text { never/ not at } \\
\text { all }\end{array}$ & $\begin{array}{l}\text { Occasionally, } \\
\text { but rarely/a } \\
\text { little bit }\end{array}$ & $\begin{array}{l}\text { Occasionally/ } \\
\text { from time to } \\
\text { time/somewhat }\end{array}$ & $\begin{array}{l}\text { Consistently/ } \\
\text { often/ a good } \\
\text { deal }\end{array}$ & $\begin{array}{l}\text { Consistently/ } \\
\text { a great deal }\end{array}$ & $\begin{array}{l}\text { Not } \\
\text { applicable }\end{array}$ \\
\hline $\begin{array}{l}\text { In the } \\
\text { past 6 } \\
\text { months: }\end{array}$ & & & & & & \\
\hline
\end{tabular}

21. How often have people said things like "I watched Will \& Grace" to show they know about gay culture?

\begin{tabular}{|l|l|l|l|l|l|l|}
\hline & $\begin{array}{l}\text { Hardly ever/ } \\
\text { never/ not at } \\
\text { all }\end{array}$ & $\begin{array}{l}\text { Occasionally, } \\
\text { but rarely/a } \\
\text { little bit }\end{array}$ & $\begin{array}{l}\text { Occasionally/ } \\
\text { from time to } \\
\text { time/somewhat }\end{array}$ & $\begin{array}{l}\text { Consistently/ } \\
\text { often/ a good } \\
\text { deal }\end{array}$ & $\begin{array}{l}\text { Consistently/ } \\
\text { a great deal }\end{array}$ & $\begin{array}{l}\text { Not } \\
\text { applicable }\end{array}$ \\
\hline $\begin{array}{l}\text { In the } \\
\text { past 6 } \\
\text { months: }\end{array}$ & & & & & & \\
\hline
\end{tabular}


22. How often have people equated themselves and their experience to yours as a minority?

\begin{tabular}{|l|l|l|l|l|l|l|}
\hline & $\begin{array}{l}\text { Hardly ever/ } \\
\text { never/ not at } \\
\text { all }\end{array}$ & $\begin{array}{l}\text { Occasionally, } \\
\text { but rarely/a } \\
\text { little bit }\end{array}$ & $\begin{array}{l}\text { Occasionally/ } \\
\text { from time to } \\
\text { time/somewhat }\end{array}$ & $\begin{array}{l}\text { Consistently/ } \\
\text { often/ a good } \\
\text { deal }\end{array}$ & $\begin{array}{l}\text { Consistently/ } \\
\text { a great deal }\end{array}$ & $\begin{array}{l}\text { Not } \\
\text { applicable }\end{array}$ \\
\hline $\begin{array}{l}\text { In the } \\
\text { past 6 } \\
\text { months: }\end{array}$ & & & & & & \\
\hline
\end{tabular}

23. How often have people indicated they know other LGB individuals by saying things like "My hairdresser is gay" or "I have a gay friend"?

\begin{tabular}{|l|l|l|l|l|l|l|}
\hline & $\begin{array}{l}\text { Hardly ever/ } \\
\text { never/ not at } \\
\text { all }\end{array}$ & $\begin{array}{l}\text { Occasionally, } \\
\text { but rarely/a } \\
\text { little bit }\end{array}$ & $\begin{array}{l}\text { Occasionally/ } \\
\text { from time to } \\
\text { time/somewhat }\end{array}$ & $\begin{array}{l}\text { Consistently/ } \\
\text { often/ a good } \\
\text { deal }\end{array}$ & $\begin{array}{l}\text { Consistently/ } \\
\text { a great deal }\end{array}$ & $\begin{array}{l}\text { Not } \\
\text { applicable }\end{array}$ \\
\hline $\begin{array}{l}\text { In the } \\
\text { past 6 } \\
\text { months: }\end{array}$ & & & & & & \\
\hline
\end{tabular}

24. How often have people showed surprise at how not effeminate (if you are a man) or not masculine (if you are a woman) you are?

\begin{tabular}{|l|l|l|l|l|l|l|}
\hline & $\begin{array}{l}\text { Hardly ever/ } \\
\text { never/ not at } \\
\text { all }\end{array}$ & $\begin{array}{l}\text { Occasionally, } \\
\text { but rarely/a } \\
\text { little bit }\end{array}$ & $\begin{array}{l}\text { Occasionally/ } \\
\text { from time to } \\
\text { time/somewhat }\end{array}$ & $\begin{array}{l}\text { Consistently/ } \\
\text { often/ a good } \\
\text { deal }\end{array}$ & $\begin{array}{l}\text { Consistently/ } \\
\text { a great deal }\end{array}$ & $\begin{array}{l}\text { Not } \\
\text { applicable }\end{array}$ \\
\hline $\begin{array}{l}\text { In the } \\
\text { past 6 } \\
\text { months: }\end{array}$ & & & & & & \\
\hline
\end{tabular}

25. How often have people assumed you like to wear clothing of the opposite sex?

\begin{tabular}{|l|l|l|l|l|l|l|}
\hline & $\begin{array}{l}\text { Hardly ever/ } \\
\text { never/ not at } \\
\text { all }\end{array}$ & $\begin{array}{l}\text { Occasionally, } \\
\text { but rarely/a } \\
\text { little bit }\end{array}$ & $\begin{array}{l}\text { Occasionally/ } \\
\text { from time to } \\
\text { time/somewhat }\end{array}$ & $\begin{array}{l}\text { Consistently/ } \\
\text { often/ a good } \\
\text { deal }\end{array}$ & $\begin{array}{l}\text { Consistently/ } \\
\text { a great deal }\end{array}$ & $\begin{array}{l}\text { Not } \\
\text { applicable }\end{array}$ \\
\hline $\begin{array}{l}\text { In the } \\
\text { past 6 } \\
\text { months: }\end{array}$ & & & & & & \\
\hline
\end{tabular}

26. How often have people made statements that you are "more normal" than they expected?

\begin{tabular}{|l|l|l|l|l|l|l|}
\hline & $\begin{array}{l}\text { Hardly ever/ } \\
\text { never/ not at } \\
\text { all }\end{array}$ & $\begin{array}{l}\text { Occasionally, } \\
\text { but rarely/a } \\
\text { little bit }\end{array}$ & $\begin{array}{l}\text { Occasionally/ } \\
\text { from time to } \\
\text { time/somewhat }\end{array}$ & $\begin{array}{l}\text { Consistently/ } \\
\text { often/ a good } \\
\text { deal }\end{array}$ & $\begin{array}{l}\text { Consistently/ } \\
\text { a great deal }\end{array}$ & $\begin{array}{l}\text { Not } \\
\text { applicable }\end{array}$ \\
\hline $\begin{array}{l}\text { In the } \\
\text { past 6 } \\
\text { months: }\end{array}$ & & & & & & \\
\hline
\end{tabular}

27. How often have people addressed you with the pronoun of the opposite sex (she/her for men, he/him for women)? 


\begin{tabular}{|l|l|l|l|l|l|l|}
\hline & $\begin{array}{l}\text { Hardly ever/ } \\
\text { never/ not at } \\
\text { all }\end{array}$ & $\begin{array}{l}\text { Occasionally, } \\
\text { but rarely/a } \\
\text { little bit }\end{array}$ & $\begin{array}{l}\text { Occasionally/ } \\
\text { from time to } \\
\text { time/somewhat }\end{array}$ & $\begin{array}{l}\text { Consistently/ } \\
\text { often/ a good } \\
\text { deal }\end{array}$ & $\begin{array}{l}\text { Consistently/ } \\
\text { a great deal }\end{array}$ & $\begin{array}{l}\text { Not } \\
\text { applicable }\end{array}$ \\
\hline $\begin{array}{l}\text { In the } \\
\text { past 6 } \\
\text { months: }\end{array}$ & & & & & & \\
\hline
\end{tabular}

28. How often have people told you to "calm down" or be less "dramatic"?

\begin{tabular}{|l|l|l|l|l|l|l|}
\hline & $\begin{array}{l}\text { Hardly ever/ } \\
\text { never/ not at } \\
\text { all }\end{array}$ & $\begin{array}{l}\text { Occasionally, } \\
\text { but rarely/a } \\
\text { little bit }\end{array}$ & $\begin{array}{l}\text { Occasionally/ } \\
\text { from time to } \\
\text { time/somewhat }\end{array}$ & $\begin{array}{l}\text { Consistently/ } \\
\text { often/ a good } \\
\text { deal }\end{array}$ & $\begin{array}{l}\text { Consistently/ } \\
\text { a great deal }\end{array}$ & $\begin{array}{l}\text { Not } \\
\text { applicable }\end{array}$ \\
\hline $\begin{array}{l}\text { In the } \\
\text { past 6 } \\
\text { months: }\end{array}$ & & & & & & \\
\hline
\end{tabular}

29. How often have people either told you to be especially careful regarding safe sex because of your sexual orientation or told you that you don't have to worry about safe sex because of your sexual orientation?

\begin{tabular}{|l|l|l|l|l|l|l|}
\hline & $\begin{array}{l}\text { Hardly ever/ } \\
\text { never/ not at } \\
\text { all }\end{array}$ & $\begin{array}{l}\text { Occasionally, } \\
\text { but rarely/a } \\
\text { little bit }\end{array}$ & $\begin{array}{l}\text { Occasionally/ } \\
\text { from time to } \\
\text { time/somewhat }\end{array}$ & $\begin{array}{l}\text { Consistently/ } \\
\text { often/ a good } \\
\text { deal }\end{array}$ & $\begin{array}{l}\text { Consistently/ } \\
\text { a great deal }\end{array}$ & $\begin{array}{l}\text { Not } \\
\text { applicable }\end{array}$ \\
\hline $\begin{array}{l}\text { In the } \\
\text { past 6 } \\
\text { months: }\end{array}$ & & & & & & \\
\hline
\end{tabular}

30. How often have people dismissed you for bringing up the issue of your sexual orientation at school or work? I

\begin{tabular}{|l|l|l|l|l|l|l|}
\hline & $\begin{array}{l}\text { Hardly ever/ } \\
\text { never/ not at } \\
\text { all }\end{array}$ & $\begin{array}{l}\text { Occasionally, } \\
\text { but rarely/a } \\
\text { little bit }\end{array}$ & $\begin{array}{l}\text { Occasionally/ } \\
\text { from time to } \\
\text { time/somewhat }\end{array}$ & $\begin{array}{l}\text { Consistently/ } \\
\text { often/a good } \\
\text { deal }\end{array}$ & $\begin{array}{l}\text { Consistently/ } \\
\text { a great deal }\end{array}$ & $\begin{array}{l}\text { Not } \\
\text { applicable }\end{array}$ \\
\hline $\begin{array}{l}\text { In the } \\
\text { past 6 } \\
\text { months: }\end{array}$ & & & & & & \\
\hline
\end{tabular}

31. How often have people stared at you or given you a dirty look when expressing affection toward someone of the same sex?

\begin{tabular}{|l|l|l|l|l|l|l|}
\hline & $\begin{array}{l}\text { Hardly ever/ } \\
\text { never/ not at } \\
\text { all }\end{array}$ & $\begin{array}{l}\text { Occasionally, } \\
\text { but rarely/a } \\
\text { little bit }\end{array}$ & $\begin{array}{l}\text { Occasionally/ } \\
\text { from time to } \\
\text { time/somewhat }\end{array}$ & $\begin{array}{l}\text { Consistently/ } \\
\text { often/a good } \\
\text { deal }\end{array}$ & $\begin{array}{l}\text { Consistently/ } \\
\text { a great deal }\end{array}$ & $\begin{array}{l}\text { Not } \\
\text { applicable }\end{array}$ \\
\hline $\begin{array}{l}\text { In the } \\
\text { past 6 } \\
\text { months: }\end{array}$ & & & & & & \\
\hline
\end{tabular}

32. How often have people made statements about LGB individuals using phrases like "you people" or "you know how gay people are"?

\begin{tabular}{|l|l|l|l|l|l|l|}
\hline $\begin{array}{l}\text { Hardly ever/ } \\
\text { all }\end{array}$ & $\begin{array}{l}\text { Occasionally, } \\
\text { but rarely/a } \\
\text { little bit }\end{array}$ & $\begin{array}{l}\text { Occasionally/ } \\
\text { from time to } \\
\text { time/somewhat }\end{array}$ & $\begin{array}{l}\text { Consistently/ } \\
\text { often/ a good } \\
\text { deal }\end{array}$ & $\begin{array}{l}\text { Consistently/ } \\
\text { a great deal }\end{array}$ & $\begin{array}{l}\text { Not } \\
\text { applicable }\end{array}$ \\
\hline
\end{tabular}




\begin{tabular}{|l|l|l|l|l|l|}
\hline In the & & & & & \\
past 6 & & & & & \\
months: & & & & & \\
\hline
\end{tabular}

33. How often have people said it would bother them if someone thought they were gay?

\begin{tabular}{|l|l|l|l|l|l|l|}
\hline & $\begin{array}{l}\text { Hardly ever/ } \\
\text { never/ not at } \\
\text { all }\end{array}$ & $\begin{array}{l}\text { Occasionally, } \\
\text { but rarely/a } \\
\text { little bit }\end{array}$ & $\begin{array}{l}\text { Occasionally/ } \\
\text { from time to } \\
\text { time/somewhat }\end{array}$ & $\begin{array}{l}\text { Consistently/ } \\
\text { often/ a good } \\
\text { deal }\end{array}$ & $\begin{array}{l}\text { Consistently/ } \\
\text { a great deal }\end{array}$ & $\begin{array}{l}\text { Not } \\
\text { applicable }\end{array}$ \\
\hline $\begin{array}{l}\text { In the } \\
\text { past } 6 \\
\text { months: }\end{array}$ & & & & & & \\
\hline
\end{tabular}

34. How often have people made statements about why gay marriage should not be allowed?

\begin{tabular}{|l|l|l|l|l|l|l|}
\hline & $\begin{array}{l}\text { Hardly ever/ } \\
\text { never/ not at } \\
\text { all }\end{array}$ & $\begin{array}{l}\text { Occasionally, } \\
\text { but rarely/a } \\
\text { little bit }\end{array}$ & $\begin{array}{l}\text { Occasionally/ } \\
\text { from time to } \\
\text { time/somewhat }\end{array}$ & $\begin{array}{l}\text { Consistently/ } \\
\text { often/ a good } \\
\text { deal }\end{array}$ & $\begin{array}{l}\text { Consistently/ } \\
\text { a great deal }\end{array}$ & $\begin{array}{l}\text { Not } \\
\text { applicable }\end{array}$ \\
\hline $\begin{array}{l}\text { In the } \\
\text { past 6 } \\
\text { months: }\end{array}$ & & & & & & \\
\hline
\end{tabular}

35. How often have people made statements against LGB individuals adopting?

\begin{tabular}{|l|l|l|l|l|l|l|}
\hline & $\begin{array}{l}\text { Hardly ever/ } \\
\text { never/ not at } \\
\text { all }\end{array}$ & $\begin{array}{l}\text { Occasionally, } \\
\text { but rarely/a } \\
\text { little bit }\end{array}$ & $\begin{array}{l}\text { Occasionally/ } \\
\text { from time to } \\
\text { time/somewhat }\end{array}$ & $\begin{array}{l}\text { Consistently/ } \\
\text { often/ a good } \\
\text { deal }\end{array}$ & $\begin{array}{l}\text { Consistently/ } \\
\text { a great deal }\end{array}$ & $\begin{array}{l}\text { Not } \\
\text { applicable }\end{array}$ \\
\hline $\begin{array}{l}\text { In the } \\
\text { past 6 } \\
\text { months: }\end{array}$ & & & & & & \\
\hline
\end{tabular}

36. How often have people (directly or indirectly) called you a derogatory name like fag, queer, homo, or dyke?

\begin{tabular}{|l|l|l|l|l|l|l|}
\hline & $\begin{array}{l}\text { Hardly ever/ } \\
\text { never/ not at } \\
\text { all }\end{array}$ & $\begin{array}{l}\text { Occasionally, } \\
\text { but rarely/a } \\
\text { little bit }\end{array}$ & $\begin{array}{l}\text { Occasionally/ } \\
\text { from time to } \\
\text { time/somewhat }\end{array}$ & $\begin{array}{l}\text { Consistently/ } \\
\text { often/ a good } \\
\text { deal }\end{array}$ & $\begin{array}{l}\text { Consistently/ } \\
\text { a great deal }\end{array}$ & $\begin{array}{l}\text { Not } \\
\text { applicable }\end{array}$ \\
\hline $\begin{array}{l}\text { In the } \\
\text { past 6 } \\
\text { months: }\end{array}$ & & & & & & \\
\hline
\end{tabular}

37. How often have people told you to act differently at work or school in order to hide your sexual orientation?

\begin{tabular}{|l|l|l|l|l|l|l|}
\hline & $\begin{array}{l}\text { Hardly ever/ } \\
\text { never/ not at } \\
\text { all }\end{array}$ & $\begin{array}{l}\text { Occasionally, } \\
\text { but rarely/a } \\
\text { little bit }\end{array}$ & $\begin{array}{l}\text { Occasionally/ } \\
\text { from time to } \\
\text { time/somewhat }\end{array}$ & $\begin{array}{l}\text { Consistently/ } \\
\text { often/ a good } \\
\text { deal }\end{array}$ & $\begin{array}{l}\text { Consistently/ } \\
\text { a great deal }\end{array}$ & $\begin{array}{l}\text { Not } \\
\text { applicable }\end{array}$ \\
\hline $\begin{array}{l}\text { In the } \\
\text { past 6 } \\
\text { months: }\end{array}$ & & & & & & \\
\hline
\end{tabular}

38. How often have people made offensive remarks about LGB individuals in your presence, not realizing your sexual orientation? 


\begin{tabular}{|l|l|l|l|l|l|l|}
\hline & $\begin{array}{l}\text { Hardly ever/ } \\
\text { never/ not at } \\
\text { all }\end{array}$ & $\begin{array}{l}\text { Occasionally, } \\
\text { but rarely/a } \\
\text { little bit }\end{array}$ & $\begin{array}{l}\text { Occasionally/ } \\
\text { from time to } \\
\text { time/somewhat }\end{array}$ & $\begin{array}{l}\text { Consistently/ } \\
\text { often/ a good } \\
\text { deal }\end{array}$ & $\begin{array}{l}\text { Consistently/ } \\
\text { a great deal }\end{array}$ & $\begin{array}{l}\text { Not } \\
\text { applicable }\end{array}$ \\
\hline $\begin{array}{l}\text { In the } \\
\text { past 6 } \\
\text { months: }\end{array}$ & & & & & & \\
\hline
\end{tabular}

39. How often have people used the phrase "that's so gay" in your presence?

\begin{tabular}{|l|l|l|l|l|l|l|}
\hline & $\begin{array}{l}\text { Hardly ever/ } \\
\text { never/ not at } \\
\text { all }\end{array}$ & $\begin{array}{l}\text { Occasionally, } \\
\text { but rarely/a } \\
\text { little bit }\end{array}$ & $\begin{array}{l}\text { Occasionally/ } \\
\text { from time to } \\
\text { time/somewhat }\end{array}$ & $\begin{array}{l}\text { Consistently/ } \\
\text { often/ a good } \\
\text { deal }\end{array}$ & $\begin{array}{l}\text { Consistently/ } \\
\text { a great deal }\end{array}$ & $\begin{array}{l}\text { Not } \\
\text { applicable }\end{array}$ \\
\hline $\begin{array}{l}\text { In the } \\
\text { past 6 } \\
\text { months: }\end{array}$ & & & & & & \\
\hline
\end{tabular}

40. How often have people told you it's wrong to be gay or said you were going to hell because of your sexual orientation?

\begin{tabular}{|l|l|l|l|l|l|l|}
\hline & $\begin{array}{l}\text { Hardly ever/ } \\
\text { never/ not at } \\
\text { all }\end{array}$ & $\begin{array}{l}\text { Occasionally, } \\
\text { but rarely/a } \\
\text { little bit }\end{array}$ & $\begin{array}{l}\text { Occasionally/ } \\
\text { from time to } \\
\text { time/somewhat }\end{array}$ & $\begin{array}{l}\text { Consistently/ } \\
\text { often/ a good } \\
\text { deal }\end{array}$ & $\begin{array}{l}\text { Consistently/ } \\
\text { a great deal }\end{array}$ & $\begin{array}{l}\text { Not } \\
\text { applicable }\end{array}$ \\
\hline $\begin{array}{l}\text { In the } \\
\text { past 6 } \\
\text { months: }\end{array}$ & & & & & & \\
\hline
\end{tabular}

41. How often have people told you to dress differently at work or school in order to hide your sexual orientation?

\begin{tabular}{|l|l|l|l|l|l|l|}
\hline & $\begin{array}{l}\text { Hardly ever/ } \\
\text { never/ not at } \\
\text { all }\end{array}$ & $\begin{array}{l}\text { Occasionally, } \\
\text { but rarely/a } \\
\text { little bit }\end{array}$ & $\begin{array}{l}\text { Occasionally/ } \\
\text { from time to } \\
\text { time/somewhat }\end{array}$ & $\begin{array}{l}\text { Consistently/ } \\
\text { often/a good } \\
\text { deal }\end{array}$ & $\begin{array}{l}\text { Consistently/ } \\
\text { a great deal }\end{array}$ & $\begin{array}{l}\text { Not } \\
\text { applicable }\end{array}$ \\
\hline $\begin{array}{l}\text { In the } \\
\text { past 6 } \\
\text { months: }\end{array}$ & & & & & & \\
\hline
\end{tabular}

42. How often have people told you not to disclose your sexual orientation in some context (like work or school)?

\begin{tabular}{|l|l|l|l|l|l|l|}
\hline & $\begin{array}{l}\text { Hardly ever/ } \\
\text { never/ not at } \\
\text { all }\end{array}$ & $\begin{array}{l}\text { Occasionally, } \\
\text { but rarely/a } \\
\text { little bit }\end{array}$ & $\begin{array}{l}\text { Occasionally/ } \\
\text { from time to } \\
\text { time/somewhat }\end{array}$ & $\begin{array}{l}\text { Consistently/ } \\
\text { often/a good } \\
\text { deal }\end{array}$ & $\begin{array}{l}\text { Consistently/ } \\
\text { a great deal }\end{array}$ & $\begin{array}{l}\text { Not } \\
\text { applicable }\end{array}$ \\
\hline $\begin{array}{l}\text { In the } \\
\text { past 6 } \\
\text { months: }\end{array}$ & & & & & & \\
\hline
\end{tabular}

43. How often have you felt that TV characters have portrayed stereotypes of LGB individuals?

\begin{tabular}{|l|l|l|l|l|l|l|}
\hline & $\begin{array}{l}\text { Hardly ever/ } \\
\text { never/ not at } \\
\text { all }\end{array}$ & $\begin{array}{l}\text { Occasionally, } \\
\text { but rarely/a } \\
\text { little bit }\end{array}$ & $\begin{array}{l}\text { Occasionally/ } \\
\text { from time to } \\
\text { time/somewhat }\end{array}$ & $\begin{array}{l}\text { Consistently/ } \\
\text { often/ a good } \\
\text { deal }\end{array}$ & $\begin{array}{l}\text { Consistently/ } \\
\text { a great deal }\end{array}$ & $\begin{array}{l}\text { Not } \\
\text { applicable }\end{array}$ \\
\hline
\end{tabular}




\begin{tabular}{|l|l|l|l|l|l|}
\hline $\begin{array}{l}\text { In the } \\
\text { past } 6 \\
\text { months: }\end{array}$ & & & & & \\
\hline
\end{tabular}

44. How often have you felt like your rights (like marriage) are denied?

\begin{tabular}{|l|l|l|l|l|l|l|}
\hline & $\begin{array}{l}\text { Hardly ever/ } \\
\text { never/ not at } \\
\text { all }\end{array}$ & $\begin{array}{l}\text { Occasionally, } \\
\text { but rarely/a } \\
\text { little bit }\end{array}$ & $\begin{array}{l}\text { Occasionally/ } \\
\text { from time to } \\
\text { time/somewhat }\end{array}$ & $\begin{array}{l}\text { Consistently/ } \\
\text { often/ a good } \\
\text { deal }\end{array}$ & $\begin{array}{l}\text { Consistently/ } \\
\text { a great deal }\end{array}$ & $\begin{array}{l}\text { Not } \\
\text { applicable }\end{array}$ \\
\hline $\begin{array}{l}\text { In the } \\
\text { past 6 } \\
\text { months: }\end{array}$ & & & & & & \\
\hline
\end{tabular}

45. How often have religious leaders spoken out against homosexuality?

\begin{tabular}{|l|l|l|l|l|l|l|}
\hline & $\begin{array}{l}\text { Hardly ever/ } \\
\text { never/ not at } \\
\text { all }\end{array}$ & $\begin{array}{l}\text { Occasionally, } \\
\text { but rarely/a } \\
\text { little bit }\end{array}$ & $\begin{array}{l}\text { Occasionally/ } \\
\text { from time to } \\
\text { time/somewhat }\end{array}$ & $\begin{array}{l}\text { Consistently/ } \\
\text { often/ a good } \\
\text { deal }\end{array}$ & $\begin{array}{l}\text { Consistently/ } \\
\text { a great deal }\end{array}$ & $\begin{array}{l}\text { Not } \\
\text { applicable }\end{array}$ \\
\hline $\begin{array}{l}\text { In the } \\
\text { past 6 } \\
\text { months: }\end{array}$ & & & & & & \\
\hline
\end{tabular}




\section{Beck Anxiety Inventory}

Below is a list of common symptoms of anxiety. Please carefully read each item in the list. Indicate how much you have been bothered by that symptom during the past month, including today, by circling the number in the corresponding space in the column next to each symptom.

\begin{tabular}{|c|c|c|c|c|}
\hline $\begin{array}{l}\text { Rate your } \\
\text { replies as } \\
\text { follows: }\end{array}$ & $\begin{array}{c}\text { NOT AT } \\
\text { ALL }\end{array}$ & $\begin{array}{l}\text { MILDLY } \\
\text { But it didn't } \\
\text { bother me too } \\
\text { much }\end{array}$ & $\begin{array}{l}\text { MODERATELY } \\
\text { It was very } \\
\text { unpleasant but I } \\
\text { could stand it }\end{array}$ & $\begin{array}{c}\text { SEVERELY } \\
\text { I could barely } \\
\text { stand it }\end{array}$ \\
\hline $\begin{array}{l}\text { 1. Numbness } \\
\text { or tingling }\end{array}$ & 0 & 1 & 2 & 3 \\
\hline 2. Feeling hot & 0 & 1 & 2 & 3 \\
\hline $\begin{array}{l}\text { 3. Wobbliness } \\
\text { in legs }\end{array}$ & 0 & 1 & 2 & 3 \\
\hline $\begin{array}{l}\text { 4. Unable to } \\
\text { relax }\end{array}$ & 0 & 1 & 2 & 3 \\
\hline $\begin{array}{l}\text { 5. Fear of } \\
\text { worst } \\
\text { happening }\end{array}$ & 0 & 1 & 2 & 3 \\
\hline $\begin{array}{l}\text { 6. Dizzy or } \\
\text { lightheaded }\end{array}$ & 0 & 1 & 2 & 3 \\
\hline $\begin{array}{l}7 . \text { Heart } \\
\text { pound/ racing }\end{array}$ & 0 & 1 & 2 & 3 \\
\hline 8. Unsteady & 0 & 1 & 2 & 3 \\
\hline $\begin{array}{l}\text { 9. Terrified or } \\
\text { afraid }\end{array}$ & 0 & 1 & 2 & 3 \\
\hline 10. Nervous & 0 & 1 & 2 & 3 \\
\hline $\begin{array}{l}\text { 11. Feeling of } \\
\text { choking }\end{array}$ & 0 & 1 & 2 & 3 \\
\hline $\begin{array}{l}\text { 12. Hands } \\
\text { trembling }\end{array}$ & 0 & 1 & 2 & 3 \\
\hline $\begin{array}{l}\text { 13. Shaky/ } \\
\text { unsteady }\end{array}$ & 0 & 1 & 2 & 3 \\
\hline $\begin{array}{l}\text { 14. Fear of } \\
\text { losing control }\end{array}$ & 0 & 1 & 2 & 3 \\
\hline $\begin{array}{l}15 . \text { Difficulty } \\
\text { in breathing }\end{array}$ & 0 & 1 & 2 & 3 \\
\hline $\begin{array}{l}\text { 16. Fear of } \\
\text { dying }\end{array}$ & 0 & 1 & 2 & 3 \\
\hline 17. Scared & 0 & 1 & 2 & 3 \\
\hline 18. Indigestion & 0 & 1 & 2 & 3 \\
\hline $\begin{array}{l}\text { 19. Faint/ } \\
\text { lightheaded }\end{array}$ & 0 & 1 & 2 & 3 \\
\hline
\end{tabular}




\begin{tabular}{|l|c|c|c|c|}
\hline $\begin{array}{l}\text { 20. Face } \\
\text { flushed }\end{array}$ & 0 & 1 & 2 & 3 \\
\hline $\begin{array}{l}\text { 21. Hot/cold } \\
\text { sweats }\end{array}$ & 0 & 1 & 2 & 3 \\
\hline
\end{tabular}


Social Support Survey Instrument

People sometimes look to others for companionship, assistance, or other types of support. How often is each of the following kinds of support available to you if you need it?

Choose one number from each line.

\begin{tabular}{|c|c|c|c|c|c|}
\hline & $\begin{array}{l}\text { None of } \\
\text { the time }\end{array}$ & $\begin{array}{l}\text { A little of } \\
\text { the time }\end{array}$ & $\begin{array}{l}\text { Some of } \\
\text { the time }\end{array}$ & $\begin{array}{l}\text { Most of } \\
\text { the time }\end{array}$ & $\begin{array}{l}\text { All of the } \\
\text { time }\end{array}$ \\
\hline \multicolumn{6}{|l|}{ Emotional/ Informational Support } \\
\hline $\begin{array}{l}\text { Someone you can count on to listen } \\
\text { to you when you need to talk }\end{array}$ & 1 & 2 & 3 & 4 & 5 \\
\hline $\begin{array}{l}\text { Someone to give you information to } \\
\text { help you understand a situation }\end{array}$ & 1 & 2 & 3 & 4 & 5 \\
\hline $\begin{array}{l}\text { Someone to give you good advice } \\
\text { about a crisis }\end{array}$ & 1 & 2 & 3 & 4 & 5 \\
\hline $\begin{array}{l}\text { Someone to confide in or talk to } \\
\text { about yourself or your problems }\end{array}$ & 1 & 2 & 3 & 4 & 5 \\
\hline $\begin{array}{l}\text { Someone whose advice you really } \\
\text { want }\end{array}$ & 1 & 2 & 3 & 4 & 5 \\
\hline $\begin{array}{l}\text { Someone to share your most private } \\
\text { worries and fears with }\end{array}$ & 1 & 2 & 3 & 4 & 5 \\
\hline $\begin{array}{l}\text { Someone to turn to for suggestions } \\
\text { about how to deal with a personal } \\
\text { problem }\end{array}$ & 1 & 2 & 3 & 4 & 5 \\
\hline $\begin{array}{l}\text { Someone who understands your } \\
\text { problems }\end{array}$ & 1 & 2 & 3 & 4 & 5 \\
\hline \multicolumn{6}{|l|}{ Tangible Support } \\
\hline $\begin{array}{l}\text { Someone to help you if you were } \\
\text { confined to bed }\end{array}$ & 1 & 2 & 3 & 4 & 5 \\
\hline $\begin{array}{l}\text { Someone to take you to the doctor if } \\
\text { you needed it }\end{array}$ & 1 & 2 & 3 & 4 & 5 \\
\hline $\begin{array}{l}\text { Someone to prepare your meals if } \\
\text { you were unable to do it yourself }\end{array}$ & 1 & 2 & 3 & 4 & 5 \\
\hline $\begin{array}{l}\text { Someone to help with daily chores if } \\
\text { you were sick }\end{array}$ & 1 & 2 & 3 & 4 & 5 \\
\hline \multicolumn{6}{|l|}{ Affectionate Support } \\
\hline $\begin{array}{l}\text { Someone who shows you love and } \\
\text { affection }\end{array}$ & 1 & 2 & 3 & 4 & 5 \\
\hline $\begin{array}{l}\text { Someone to love and make you feel } \\
\text { wanted }\end{array}$ & 1 & 2 & 3 & 4 & 5 \\
\hline Someone who hugs you & 1 & 2 & 3 & 4 & 5 \\
\hline Positive Social Interaction & 1 & 2 & 3 & 4 & 5 \\
\hline Someone to have a good time with & 1 & 2 & 3 & 4 & 5 \\
\hline $\begin{array}{l}\text { Someone to get together with for } \\
\text { relaxation }\end{array}$ & 1 & 2 & 3 & 4 & 5 \\
\hline
\end{tabular}




\begin{tabular}{|l|l|l|l|l|l|l|}
\hline $\begin{array}{l}\text { Someone to do something enjoyable } \\
\text { with }\end{array}$ & 1 & 2 & 3 & 4 & 5 \\
\hline Additional Item & 1 & 2 & 3 & 4 & 5 \\
\hline $\begin{array}{l}\text { Someone to do things with to help } \\
\text { you get your mind off things }\end{array}$ & 1 & & & & \\
\hline
\end{tabular}




\section{Outness Inventory}

Use the following rating scale to indicate how open you are about your sexual orientation to the people listed below. Try to respond to all of the items, but leave items blank if they do not apply to you. If an item refers to a group of people (e.g., work peers), then indicate how out you generally are to that group.

$1=$ person definitely does NOT know about your sexual orientation status

$2=$ person might know about your sexual orientation status, but it is NEVER talked about

$3=$ person probably knows about your sexual orientation status, but it is NEVER talked about

4 = person probably knows about your sexual orientation status, but it is RARELY talked about

$5=$ person definitely knows about your sexual orientation status, but it is RARELY

talked about

$6=$ person definitely knows about your sexual orientation status, and it is SOMETIMES

talked about

$7=$ person definitely knows about your sexual orientation status, and it is OPENLY

talked about

$0=$ not applicable to your situation; there is no such person or group of people in your life

\begin{tabular}{|l|l|l|l|l|l|l|l|l|}
\hline 1. mother & 1 & 2 & 3 & 4 & 5 & 6 & 7 & 0 \\
\hline 2. father & 1 & 2 & 3 & 4 & 5 & 6 & 7 & 0 \\
\hline 3. siblings (sisters, brothers) & 1 & 2 & 3 & 4 & 5 & 6 & 7 & 0 \\
\hline 4. extended family/ relatives & 1 & 2 & 3 & 4 & 5 & 6 & 7 & 0 \\
\hline 5. my new straight friends & 1 & 2 & 3 & 4 & 5 & 6 & 7 & 0 \\
\hline 6. my work peers & 1 & 2 & 3 & 4 & 5 & 6 & 7 & 0 \\
\hline 7. my work supervisors & 1 & 2 & 3 & 4 & 5 & 6 & 7 & 0 \\
\hline $\begin{array}{l}\text { 8. members of my religious } \\
\text { community (e. g., church, temple) }\end{array}$ & 1 & 2 & 3 & 4 & 5 & 6 & 7 & 0 \\
\hline $\begin{array}{l}\text { 9. leaders of my religious } \\
\text { community (e. g., church, temple) }\end{array}$ & 1 & 2 & 3 & 4 & 5 & 6 & 7 & 0 \\
\hline 10. strangers, new acquaintances & 1 & 2 & 3 & 4 & 5 & 6 & 7 & 0 \\
\hline 11. my old heterosexual friends & 1 & 2 & 3 & 4 & 5 & 6 & 7 & 0 \\
\hline
\end{tabular}




\section{Beck Depression Inventory-II}

Instructions: This questionnaire consists of 21 groups of statements. Please read each group of statements carefully, and then pick out the one statement in each group that best describes the way you have been feeling during the past two weeks, including today. Fill in the circle with the number beside the statement you have picked. If several statements in the group seem to apply equally well, circle the highest number for that group. Be sure that you do not choose more than one statement for any group, including Item 16 (Changes in Sleeping Pattern) or Item 18 (Changes in Appetite).

1. Sadness

0. I do not feel sad.

1. I feel sad much of the time.

2. I am sad all the time.

3. I am so sad or unhappy that I can't stand it

2. Pessimism

0 . I am not discouraged about my future.

1. I feel more discouraged about my future than I used to be.

2. I do not expect things to work out for me.

3. I feel my future is hopeless and will only get worse.

\section{Past Failure}

0 . I do not feel like a failure.

1. I failed more than I should have.

2. As I look back, I see a lot of failures.

3. I feel like I am a total failure as a person.

\section{Loss of Pleasure}

0 . I get as much pleasure as I ever did from the things I enjoy.

1. I don't enjoy things as much as I used to.

2. I get very little pleasure from the things I used to enjoy.

3. I can't get any pleasure from the things I used to enjoy.

5. Guilty Feelings

0 . I don't feel particularly guilty.

1. I feel guilty over many things I have done or should have done.

2. I feel quite guilty most of the time.

3. I can't get any pleasure from the things I used to enjoy.

6. Punishment Feelings

0 . I don't feel like I am being punished.

1. I feel I may be punished.

2. I expect to be punished.

3. I feel I am being punished.

7. Self-Dislike

0 . I feel the same about myself as ever.

1. I have lost confidence in myself.

2. I am disappointed in myself.

3. I dislike myself. 


\section{Self-Criticalness}

0 . I don't criticize or blame myself more than usual.

1. I am more critical of myself than I used to be.

2. I criticize myself for all my faults.

3. I blame myself for everything bad that happens.

9. Suicidal Thoughts or Wishes

0 . I don't have any thoughts of killing myself.

1. I have thoughts of killing myself, but I would not carry them out.

2. I would like to kill myself.

3. I would kill myself if I had the chance.

10. Crying

0 . I don't cry anymore than I used to.

1. I cry more than I used to.

2. I cry over every little thing.

3. I feel like crying, but I can't.

11. Agitation

0 . I am no more restless or wound up than usual.

1. I feel more restless or wound up than usual.

2. I am so restless or agitated that it's hard to stay still.

3. I am so restless or agitated that I have to keep moving or doing something.

12. Loss of Interest

0 . I have not lost interest in other people or activities.

1. I am less interested in other people or things than before.

2. I have lost most of my interest in other people or things.

3. It's hard to get interested in anything.

13. Indecisiveness

0 . I make decisions about as well as ever.

1. I find it more difficult to make decisions than usual.

2. I have much greater difficulty in making decisions than I used to.

3. I have trouble making any decisions.

14. Worthlessness

0 . I do not feel I am worthless.

1. I don't consider myself as worthwhile and useful as I used to.

2. I feel more worthless as compared to other people.

3. I feel utterly worthless.

15. Loss of Energy

0 . I have as much energy as ever.

1. I have less energy than I used to have.

2. I don't have enough energy to do very much.

3. I don't have enough energy to do anything.

16. Changes in sleeping pattern

0 . I have not experienced any change in my sleeping pattern.

1. I sleep somewhat more than usual.

1. I sleep somewhat less than usual.

2. I sleep a lot more than usual.

2. I sleep a lot less than usual. 
3. I sleep most of the day.

3. I wake up 1-2 hours early and can't get back to sleep.

17. Irritability

0 . I am no more irritable than usual.

1. I am more irritable than usual.

2. I am much more irritable than usual.

3. I am irritable all the time.

18. Changes in Appetite

0 . I have not experienced any change in my appetite.

1. My appetite is somewhat less than usual.

1. My appetite is somewhat greater than usual.

2. My appetite is much less than before.

2. My appetite is much greater than usual.

3. I have no appetite at all.

3 . I crave food all the time.

19. Concentration difficulty

0 . I can concentrate as well as ever.

1. I can't concentrate as well as usual.

2. It's hard to keep my mind on anything for very long.

3. I find I can't concentrate on anything.

20. Tiredness or Fatigue

0 . I am no more tired or fatigued than usual.

1. I get more tired or fatigued more easily than usual.

2. I am too tired or fatigued to do a lot of the things I used to do.

3. I am too tired or fatigued to do most of the things I used to do.

21. Loss of Interest in Sex

0 . I have not noticed any recent change in my interest in sex.

1. I am less interested in sex than I used to be.

2. I am much less interested in sex now.

3. I have lost interest in sex completely. 


\section{CURRICULUM VITAE}

Ghazel Tellawi

2112 Pleasant Ave, Apt. 211, Minneapolis, MN 55404

832-526-5419 | gtellawi@umn.edu

\section{Educational Experience}

\section{Doctor of Philosophy in Clinical Psychology, in progress}

University of Louisville, Louisville, $\mathrm{KY}$

July 2013-Present

- GPA 3.98/4.0

Dissertation: Microaggressions in LGB individuals: The protective role of positive LGB identity.

- Submitted as departmental $3^{\text {rd }}$ year preliminary examination requirement $\circ$ Distinguished Pass

Master of Arts in Clinical Psychology

August 2010-May 2013

University of Houston- Clear Lake, Houston, TX

- GPA 3.937/4.0

Bachelor of Arts in Psychology, cum laude

August 2005-May 2009

University of St. Thomas, Houston, TX

- GPA 3.34/4.0

\section{Clinical Experience}

\section{Doctoral Intern}

August 2017-

\section{Present}

Ball State University Counseling Center, Muncie, IN

Area of Focus Supervisor: Dr. Azadeh Fatemi (January 2017-Present); Dr. Pei-Yi Lin (Aug. 2017-Dec. 2017)

Supervisor: Dr. Khanh Nghiem (January 2017-Present); Dr. Azadeh Fatemi (Aug. 2017-Dec. 2017)

- Area of Focus- LGBTQ+ Concerns

- Provide short-term psychotherapy to individuals from diverse backgrounds and a range of presenting concerns 
- Co-lead process group

- Provide weekly supervision to two master's level trainees

- Participate in two outreach teams, including Suicide Prevention Outreach Team and Diversity Outreach Team

- Responsibilities include providing mental health presentations to various organizations on campus, co-leading Safe Zone and Transgender Safe Zone trainings, prepare and provide a presentation to school counselors from Indiana on working with transgender students, and connecting with Spectrum, an LGBTQ+ organization on campus.

- Conduct focus groups as part of a social justice project that aims to understand the experience of individuals who identify as bisexual

\section{Clinical Practicum Student}

July 2017

Psychological Services Center (PSC), University of Louisville, Louisville, KY

Supervisor: Dr. Richard Lewine (August 2015 - Present)

Supervisor: Dr. Monnica Williams (August 2014-August 2015)

Supervisor: Dr. Paul Rosen (August 2013 - August 2014)

- Utilize an integrated interventions approach to provide psychotherapy for clients with varied psychosocial difficulties from a diverse range of ethnic backgrounds, sexual orientations, and socioeconomic statuses

- Conduct semi-structured clinical interview and write integrated reports

- Administer intelligence and psychodiagnostic assessments such as the ADIS-IV, CFI, MCMI-III, MMPI-II, WAIS-IV, WISC-IV and WJ-III

\section{Graduate Practicum}

Behavioral Wellness Counseling Clinic, Louisville, KY

June 2015-June 2017

Supervisor: Dr. Nick Flower (August 2015-February 2016)

Supervisor: Dr. Monnica Williams (June 2015-Present)

- Provide evidence based treatments for individuals with various disorders, including OCD, PTSD, gender dysphoria, and major depression

- Work with several clients from ethnic and sexual minority groups

- Administer and score a number of measures, including BAI, BDI-II, SDS, MINI, SCID, and YBOCS-II

\section{Graduate Practicum}

Supervisor: Jonathon Kanter (January 2016-August 2016)

Supervisor: Gareth Holman (January 2016-June 2016)

Global Health Initiative, Louisville, KY

- Provided mental health screenings in a hospital setting to refugees from Cuba, Syria, and other countries 
- Assessments administered include the ADIS, PCL-5, Refugee Health Screener, BAI, and BDI-II

- Worked with a Spanish speaking translator during assessments

- Conducted assessment/therapy sessions in Arabic (Syrian dialect)

Graduate Internship

The Women's Home, Houston, TX

August 2012-May 2013

- Provided one on one therapy to four women with comorbid disorders, including substance abuse, bipolar disorder, and anxiety disorders

- Administered and scored a number of measures to conduct intake assessments, including the BDI, BAI, and the CAAPE

- Co-facilitated psychoeducational groups, such as relapse prevention and anger management, and goal-setting groups

\section{Clinical Practicum Student}

July 2010-

May 2013

Psychological Services Clinic (PSC), University of Houston-Clear Lake, Houston, TX

Supervisor: Dr. Norwood (August 2011 - May 2013)

- Treat clients from a wide array of backgrounds using an Acceptance and Commitment Therapy approach to treatment

- Administer intelligence, personality, and psychodiagnostic assessments such as the MMPI-II, WAIS-IV, WISC-IV, WJ-III, PAI, and NEO-PI-R

Undergraduate Internship

Children's Assessment Center, Houston, TX

December 2008-January 2010

- Worked with children who were victims of sexual abuse.

- Provided a safe and positive environment for the children between individual and group therapy sessions, medical assessments, family visits, forensic interviews, and placement in foster care.

\section{Clinical Volunteer Experience}

International OCD Foundation (IOCDF) Support Group July 2015-July 2016

- Conducted support groups at the annual IOCDF conference for family members of individuals with OCD and individuals with sexual and aggressive obsessions

\section{Teaching Experience}

\section{Teaching Assistant}

University of Louisville, Louisville, KY

Supervisor: Dr. Alison McLeish

- Aided in grading of assignments and provided assistance to students in an undergraduate Personality course 
Supervisor: Dr. Edna Ross

- Provide assistance to undergraduate students in a Developmental Psychology course

- Organized a panel to discuss differences in cultures, specifically individualistic and collectivist cultures

Teaching Assistant

University of Louisville, Louisville, KY

August 2016-December 2016

Supervisor: Dr. Melinda Leonard

- Aid in instruction and scoring of 25 students in an Honor's Lifespan Developmental Psychology course

Teaching Assistant

University of Louisville, Louisville, KY

January 2016-April 2016

Supervisor: Dr. Christian Stilp

- Taught statistics lab to two classes of roughly 20-25 undergraduate students

- Met personally with students for one on one instruction

Teaching Assistant

University of Louisville, Louisville, KY

Supervisor: Dr. Nicholaus Noles

- Administered assistance to undergraduate students in a Cognitive Processes course

- Scored exams and homework assignments

Teaching Assistant

University of Louisville, Louisville, KY

August 2015-December 2015

Supervisor: Dr. Lora Haynes

- Provided instruction to undergraduate students in a Social Psychology Class

- Aided in scoring of essays and homework assignments

Instructor's Assistant

University of Houston- Clear Lake, Houston, TX

January 2013- May 2013

Supervisor: Dr. Steve Bistricky

- Administered assistance to master's students in a Personality Assessment course

- Scored several personality measures, including the NEO and PAI, using computer software, and generated reports for students

- Graded student-generated personality reports and inputted grades into online database

Instructor's Assistant

University of Houston- Clear Lake, Houston, TX

August 2011- May 2012

Supervisor: Dr. Sarah Lechago 
- Provided one on one and group assistance to undergraduate students in a Research Methods course

- Graded assignments and inputted grades into database

\section{Work Experience}

\section{Enrichment Program Instructor}

Yancy Life Transition Center, Houston, TX

September 2009-July 2010

- Instructed 3 groups of approximately 15-20 elementary students in chess in an after school program and tutored 6 groups of 5 students in elementary math.

- Developed course outline and activities for each lesson.

\section{Research Publications}

Williams, M. T., Ching, T. H. W., Tellawi, G., Dowell, J., Slimowicz, J., Siev, J., Schlaudt, V., \& Wetterneck, C. T. (in press). Assessing sexual orientation symptoms in obsessive-comulsive disorder: Development and validation of the Sexual Orientation Obsessions and Reactions Test (SORT). Behavior Therapy.

DeLapp, R.C.T., Chasson, G. S., Swerbilow, J., Gibby, B., Tellawi, G., \& Williams, M. T. (in press). The normative nature of aggressive intrusive thinking among an underserved incarcerated population. International Journal of Offender Therapy and Comparative Criminology.

Tellawi, G., Williams, M. T., \& Chasson, G. (2016). Interpersonal hostility and suspiciousness in obsessive-compulsive disorder. Psychiatry Research, 243, 295302.

Williams, M., Wetterneck, C., Tellawi, G., \& Duque, G. (2015). Domains of distress among people with sexual orientation obsessions. Archives of Sexual Behavior, 44, 783-789.

Williams, M. T., Tellawi, G., Davis, D. M., \& Slimowicz, J. (2015). Assessment and treatment of sexual orienation obsessions in obsessive-compulsive disorder. The ACPARLAN: Australian Clinical Psychologist, 1, 12-18.

Williams, M. T., Slimowicz, J., Tellawi, G., \& Wetterneck, C. (2014). Sexual orientation symptoms in obsessive compulsive disorder: Assessment and treatment with cognitive behavioral therapy. Directions in Psychiatry, 34(1), 37-50.

Williams, M. T., Tellawi, G., Wetterneck, C. T., \& Chapman, L. K. (2013). Recruitment of ethnoracial minorities for mental health research. The Bebavior Therapist, 36, 151-156.

\section{Book Chapters}


Williams, M. T., Sawyer, B., Ellsworth, M., Singh, R., \& Tellawi, G. (2017). Obsessive-compulsive disorder in ethnoracial minorities: Attitudes, stigma, \& barriers to treatment. In J. Abramowitz, D. McKay, \& E. Storch (Eds.), Handbook of Obsessive-Compulsive Related Disorders, Vol 1. Wiley.

Williams, M. T., Chapman, L. K., Simms, J. V., \& Tellawi, G. (2017). Cross-cultural phenomenology of obsessive-compulsive disorder. In J. Abramowitz, D.

McKay, \& E. Storch (Eds.), Handbook of Obsessive-Compulsive Related Disorders, Vol 2. Wiley.

Wetterneck, C. T., Williams, M., Tellawi, G., \& Bruce, S. L. (2016). Obsessions of Suicide in Obsessive-Compulsive Disorder with Comorbid Major Depressive Disorder. In E. Storch \& Lewin (Eds.), Clinical Handbook of Obsessive-Compulsive and Related Disorders: A Case-Based Approach to Treating Pediatric and Adult Populations (pp. 431-445). Springer.

\section{Conference Talks}

Tellawi, G., Davis, D., Leins, C., Viscusi, J., \& Williams, M. (2016, July). OCD and Minority Status: Therapeutic Considerations. Panel discussion at presented at the International OCD Foundation Conference, Chicago, IL.

Tellawi, G., Duque, G., Williams, M., \& Wetterneck, C. (2012, April). Distress Associated With Sexual Orientation Obsessions in OCD. Talk presented at the University of Houston-Clear Lake 18th Annual Student Research Conference for Resarch \& Creative Arts, Houston, TX.

Williams, M., Tellawi, G., \& Wetterneck, C. (2011, November). Understanding Sexual Orientation Obsessions in OCD. Talk presented at the $45^{\text {th }}$ Annual Convention of the Association of Behavioral and Cognitive Therapies, Toronto, ON.

\section{Lectures by Invitation}

Tellawi, G. \& Lewis, B. (2018, March). Supporting Transgender Students. Lecture in preparation for the Indiana Academy Guidance Counselor Day.

Tellawi, G. (2016, April). Mental Health Issues in LGBT Populations and LGBTAffirming Treatment. Webinar presented for the Community Technical Assistance Center of New York, NYU Silver School of Social Work Field Learning and Community Partnerships and the Division of Lifelong Learning, NY (1 CE).

Ellsworth, M. \& Tellawi, G. (2015, October). Mental Health Disparities in Lesbian, Gay, Bisexual, and Transgender (LGBT) Populations. Workshop given at the University of Louisville Health Sciences Campus. 
Ellsworth, M., Tellawi, G., \& Sawyer, B. (2015, April). Mental Health Issues in LGB Populations: Minority Stress, the Coming Out Process, and LGB-Sensitive Therapy. Lecture given at the University of Louisville.

Williams, M. T., Sawyer, B. A., \& Tellawi, G. (2014, September). Assessing Obsessive-Compulsive Disorder in Diverse Populations. Workshop given at the Center for Mental Health Disparities, University of Louisville, Louisville, KY.

Tellawi, G. \& Williams, M. T. (2014, March). Obsessions of Suicide in Obsessive Compulsive Disorder. Graduate lecture given at the University of Louisville $50^{\text {th }}$ Anniversary Ph. D. Graduates Reunion.

\section{Poster Presentations}

Ching, T. H. W., Williams, M., Siev, J., Tellawi, G., Dowell, J., Schauldt, V., Slimowicz, J., Davis, D., \& Wetterneck, C. (2017, July). Assessing sexual orientation-obsessive compulsive disorder symptoms: Development and validation of the sexual orientation worries and cognitions scale (SOWACS). Poster presented at the 24th International OCD Foundation Annual Conference, San Francisco, CA.

Tellawi, G., Dowell, J., Ellsworth, M., Ching, T., Slimowicz, J., Davis, D., \& Williams, M. (2016, October). Anxiety, self-compassion, identity, and social support in sexual minority individuals. Poster presented at the Association for Cognitive and Behavioral Therapies, New York, NY.

Peña, A., Mier-Chairez, J., Bosson, R., Kotey, S., Exposito, A., Ford, R., Stephens, J., Davis, D., Tellawi, G., Sawyer, B., Debreaux, M., Carrico, R., Rashid, S., Williams, M., Frazier, V. (2016, October). Validation of the refugee health screener-15 (RHS-15) for Cuban refugees/entrants: University of Louisville Global Health Center. Poster session presented at Research! Louisville, Louisville, $\mathrm{KY}$.

Peña, A., Mier-Chairez, J., Bosson, R., Exposito, A., Ford, R., Diaz, Y., Davis, D., Tellawi, G., Sawyer, B., Debreaux, M., Carrico, R., Rashid, S., Williams, M., Frazier, V. (2016, September). Validation of the refugee health screener (RHS15) for Cuban refugees/entrants. Poster session presented at the National Latina/o Psychological Association biennial conferencia, Orlando, FL.

Ching, T. H. W., Williams, M., Olatunji, B. O., Siev, J., Davis, D., Tellawi, G., Ellsworth, M., \& Davis, D. (2016, July). Importance/Control of Thoughts Moderates the Relationship between Contamination Disgust and Sexual Orientation-OCD Symptoms: Avoiding Sexual Orientation Transformation? Poster presented at the International OCD Foundation Conference, Chicago, IL. Research Poster Scholarship Award Winner.

Tellawi, G., Ellsworth, M., Slimowicz, J., \& Williams, M. (2015, November). The Intersection between Sexual Minority Identity Development and Religiosity. 
Poster presented at the Association for Cognitive and Behavioral Therapies, Chicago, IL.

Ellsworth, M., Tellawi, G., Salmon, P., \& Williams, M. (2015, November). Psychopathology in Sexual Minorities: The Role of Self-Compassion. Poster presented at the Association for Cognitive and Behavioral Therapies, Chicago, IL.

Tellawi, G., Viscusi, J., Miller, A., Williams, M., \& Chasson, G. S. (2015, August). OCD and Marital Satisfaction: A Comparison of Individuals with OCD and their Spouses. Poster presented at the International OCD Foundation Conference, Boston, MA.

Ellsworth, M., Tellawi, G., Dowell, J., Salmon, P., \& Williams, M. (2015, March). The Role of Self-Compassion in Mental Health Outcomes of Sexual Minorities. Poster presented at the Kentucky Psychological Foundation Spring Academic Conference, Midway, KY.

Ellsworth, M., Tellawi, G., Slimowicz, J., \& Williams, M. (2014, November). Shame, Religiosity, and Internalized Homophobia in Gay and Bisexual Men. Poster presented at the Association of Behavioral and Cognitive Therapies, Philadelphia, PA.

Tellawi, G., Sawyer, B. A., Davis, D. M, Bruce, S. L., Viscusi, J., Lewis, C., \& Williams, M. (2014, July). Obsessive Compulsive Disorder and Marital Satisfaction. Poster presented at the International OCD Foundation Annual Conference, Los Angeles, CA.

Davis, D. M., Sawyer, B. A., Combs, J., Tellawi, G., Slimowicz, J., \& Williams, M. T. (2014, March). Suicidal ideation and obsessive compulsive symptoms: Dimensionality impacting risk. Poster presented at the $34^{\text {th }}$ Annual Anxiety Disorders of Association of America Conference, Chicago, IL.

Tellawi, G., Dimitrova, V., Bach, N., Steinberg, D., Williams, M. T., \& Wetterneck, C. (2014, March). Experiential Avoidance and Romantic Relationships in OCD. Poster presented at the Anxiety and Depression Association of America Annual Conference, Chicago, IL.

Tellawi, G., Bruce, S., Lewis, C., \& Williams, M.T. (2014, March). Psychometric properties of the Inventory of Hostility and Suspiciousness in Students and Outpatients with OCD. Poster presented at the $34^{\text {th }}$ Annual Anxiety and Depression Association of America Annual Conference, Chicago, IL.

Tellawi, G., Leavell, S., Bach, N., \& Williams, M. T. (2013, November). Obsessions of Suicide in Obsessive-Compulsive Disorder. Poster presented at the Association of Behavioral and Cognitive Therapies, Nashville, TN.

Bach, N., Tellawi, G., Steinberg, D., Williams, M. T., \& Wetterneck, C. (2013, November). Obsessive-Compulsive Disorder and Experiential Avoidance in Romantic Relationships. Poster presented at the Association of Behavioral and Cognitive Therapies, Nashville, TN. 
Buckner, E.V., Keen, A.N., Tellawi, G., \& Williams, M.T. (2013, July). Hostility and Suspicious Thinking in OCD. Poster Presented at the International ObsessiveCompulsive Disorder Foundation Conference, Atlanta, GA.

Duque, G., Tellawi, G., Russian, N., Wetterneck, C., Leonard, R. C., \& Riemann, B. C. (2012, November). Are Any Obsessional Beliefs Metacognitions? Findings from a Residential OCD Sample. Poster Presented at the Association of Behavioral and Cognitive Therapies Convention, National Harbor, MD.

Salazar, S., Tellawi, G., Wetterneck, C., Moore, C., \& Smith, J. L. (2012, July). Scrupulosity: Prevalence of Thoughts, Presentation of Rituals, and Predictors of Distress in a Non-Clinical Sample. Poster Presented at the International ObsessiveCompulsive Disorder Foundation Conference, Chicago, IL.

Tellawi, G., Smith, A., Osegueda, A., Norton, P., Wetterneck, C., \& Williams, M. (2012, July). Investigating OCD Symptom Dimensions across African Americans, Asians, Caucasians, and Latinos: Results from a non-clinical sample. Poster Presented at the International Obsessive-Compulsive Disorder Foundation Conference, Chicago, IL.

Tellawi, G., Williams, M., \& Wetterneck, C. (2011, July). Distress Related to Sexual Orientation Obsessions in OCD. Poster Presented at the International ObsessiveCompulsive Disorder Foundation Conference, San Diego, CA.

Duque, G., Tellawi, G., Bautista, J., \& Gonzales, L. (2011, April). Social Power \& Empathy. Poster Presented at University of Houston-Clear Lake 17 th Annual Student Conference for Research \& Creative Arts, Houston, TX.

Tellawi, G., Williams, M., \& Wetterneck, C. (2011, April). Understanding Sexual Orientation Obsessions in OCD. Poster Presented at University of Houston-Clear Lake $17^{\text {th }}$ Annual Student Conference for Research \& Creative Arts, Houston, TX. Alexander, E., Ali, Y., Duque, G., \& Tellawi, G. (2009, April). Effects of Self Awareness and Religious Imagery on Altruistic Behavior. Poster presented at $7^{\text {th }}$ Annual Southwestern Psychological Association Conference, San Antonio, TX.

Alexander, E., Ali, Y., Duque, G., \& Tellawi, G. (2009, April). Body Esteem Interaction: Promoting positive body esteem through peer intervention and mediation. Poster presented at 2009 University of St. Thomas Research Symposium, Houston, TX.

Alexander, E., Ali, Y., Duque, G., \& Tellawi, G. (2009, April). Effects of Self Awareness and Religious Imagery on Altruistic Behavior. Poster presented at 2009 University of St. Thomas Research Symposium, Houston, TX.

Tellawi, G., Garcia, A., \& Ramirez, J. (2009, April). Physical Well-Being in College Professors. Poster presented at 2009 University of St. Thomas Research Symposium, Houston, TX. 


\section{Grants Received}

Principal Investigator: Monnica Williams

Award Dates: July 1, 2015-June 22, 2016

Source: University of Louisville College of Arts and Sciences

Project Title: Sexual Orientation Obsessions in OCD

Direct Costs: $\$ 500$

\section{Academic Honors}

University Fellowship, University of Louisville

Chhavi Bhatia Memorial Scholarship

Cum Laude, University of St. Thomas

Psi Chi Honor Society

Who's Who Among American College Students

SWPA Regional Research Award

Dean's List, University of St. Thomas

President's Scholarship

Syrian-American Scholarship
Awarded 2013

Awarded 2011

Awarded 2009

Member since 2009

April 2009

April 2009

Awarded 2008, 2009

Awarded 2005

Awarded 2005

\section{Professional Associations}

APA Division 44

November 2016-Present

- Society for the Psychological Study of Lesbian, Gay, Bisexual and Transgender Issues (SPSLGBTI)

Anxiety and Depression Association of America (ADAA) March 2014-Present Association for Behavioral and Cognitive Therapies (ABCT) November 2011-Present International Obsessive-Compulsive Disorder Foundation (IOCDF) July 2011Present

Southwestern Psychological Association (SWPA)

June 2005-June 2009

\section{Certifications}

Functional Analytic Psychotherapy (FAP)- Level 1

August 2015 